Prepared in cooperation with Lincoln County, New Mexico

\title{
Water Resources During Drought Conditions and Postfire Water Quality in the Upper Rio Hondo Basin, Lincoln County, New Mexico, 2010-13
}

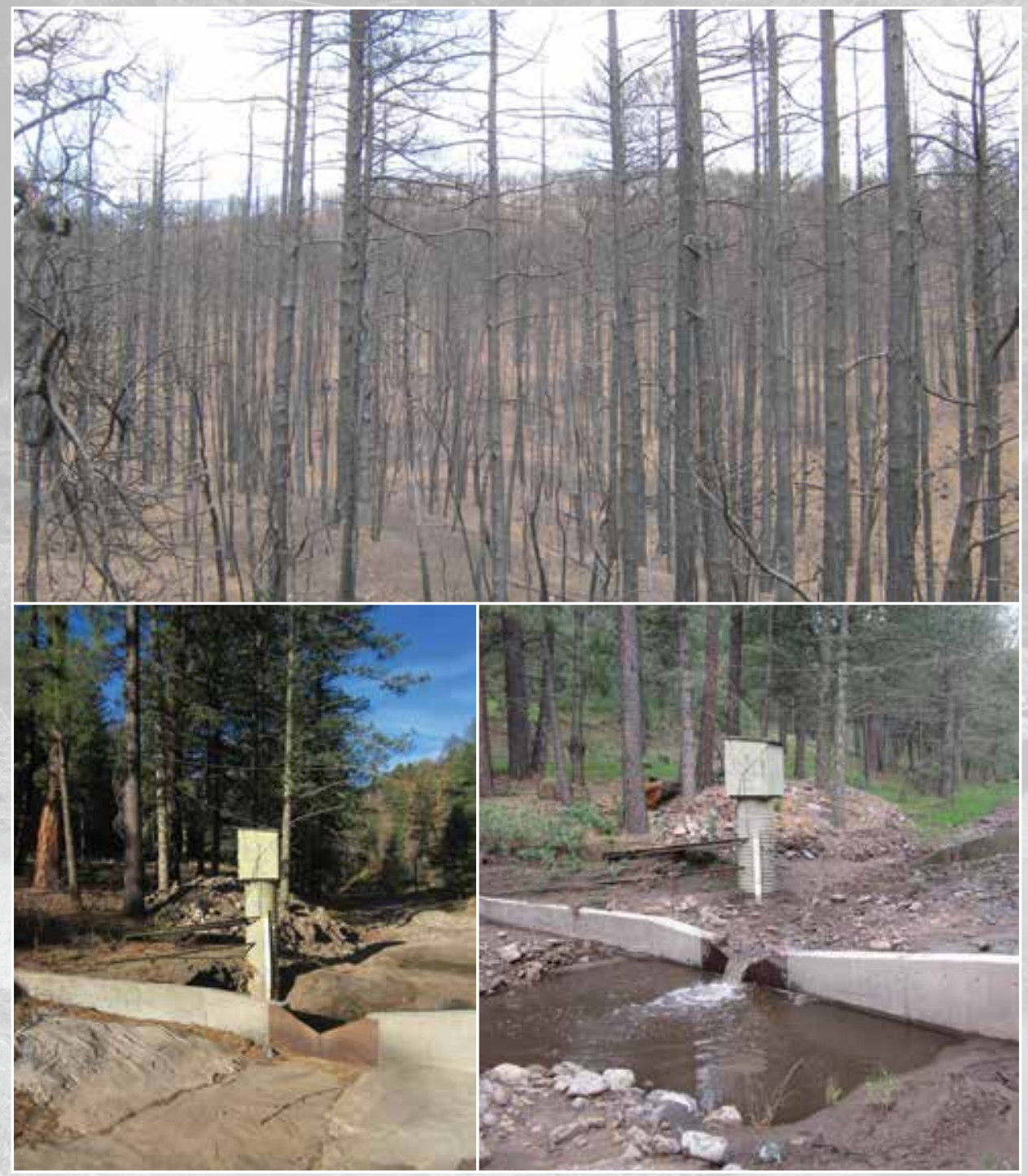

Scientific Investigations Report 2015-5086 


\section{Cover:}

Top, Burned forest near Bonito Lake after Little Bear Fire in June 2012 (U.S. Geological Survey photograph by Michael J. Darr, July 2012).

Bottom, Streamflow-gaging station located on Eagle Creek below South Fork near Alto, New Mexico, April 2013 (left) and July 2013 (right) (U.S. Geological Survey photographs by Lauren R. Sherson). 


\section{Water Resources During Drought Conditions and Postfire Water Quality in the Upper Rio Hondo Basin, Lincoln County, New Mexico, 2010-13}

By Lauren R. Sherson and Steven E. Rice

Prepared in cooperation with Lincoln County, New Mexico

Scientific Investigations Report 2015-5086 


\title{
U.S. Department of the Interior SALLY JEWELL, Secretary
}

\section{U.S. Geological Survey \\ Suzette M. Kimball, Acting Director}

\author{
U.S. Geological Survey, Reston, Virginia: 2015
}

For more information on the USGS - the Federal source for science about the Earth, its natural and living resources, natural hazards, and the environment—visit http://www.usgs.gov or call 1-888-ASK-USGS.

For an overview of USGS information products, including maps, imagery, and publications, visit http://www.usgs.gov/pubprod/.

Any use of trade, firm, or product names is for descriptive purposes only and does not imply endorsement by the U.S. Government.

Although this information product, for the most part, is in the public domain, it also may contain copyrighted materials as noted in the text. Permission to reproduce copyrighted items must be secured from the copyright owner.

Suggested citation:

Sherson, L.R. and Rice, S.E., 2015, Water resources during drought conditions and postfire water quality in the upper Rio Hondo Basin, Lincoln County, New Mexico, 2010-13: U.S. Geological Survey Scientific Investigations Report 2015-5086, 56 p., http://dx.doi.org/10.3133/sir20155086.

ISSN 2328-0328 (online) 


\section{Contents}

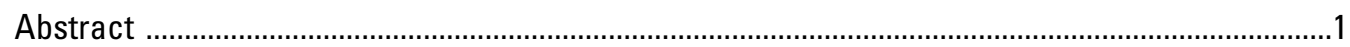

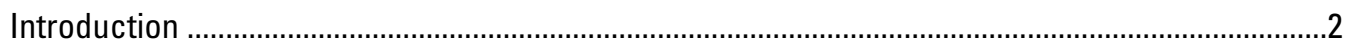

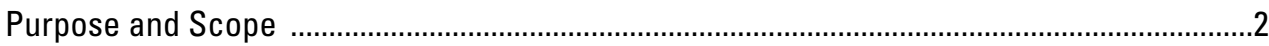

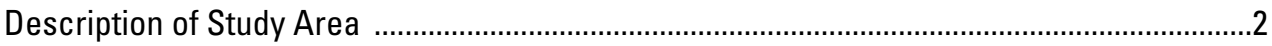

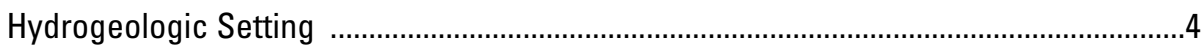

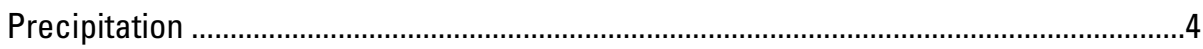

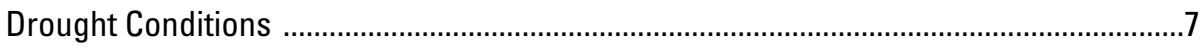

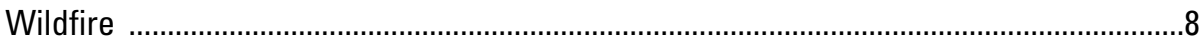

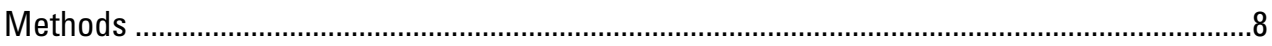

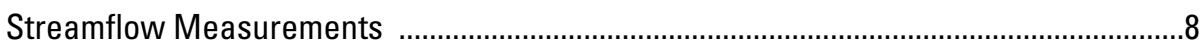

Groundwater-Level Measurements .......................................................................12

Determination of Recharge Mechanisms Using Isotopes ...........................................12

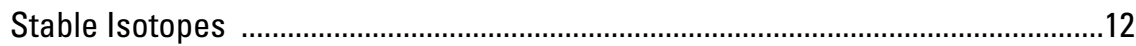



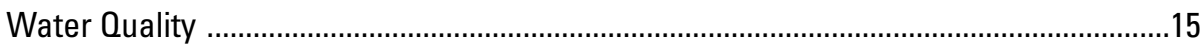

Quality-Control Samples ....................................................................................16

Water Resources During Drought Conditions .............................................................................3



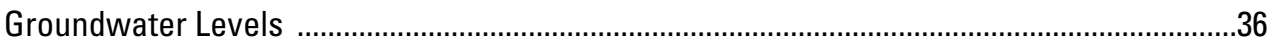

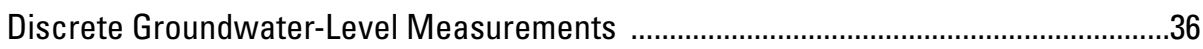

Continuous Groundwater-Level Measurements .........................................................39

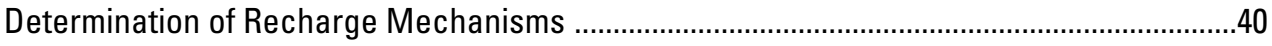

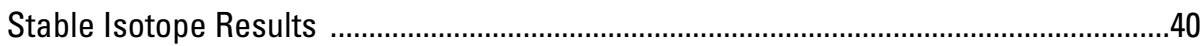

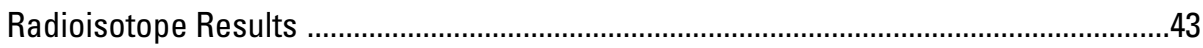

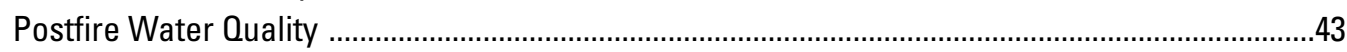

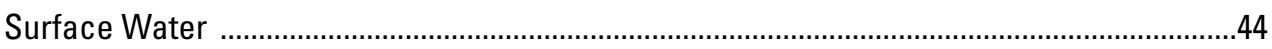

General Chemistry and Historical Comparison ...........................................................44

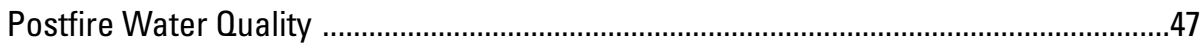

General Groundwater Chemistry and Historical Comparison .................................................49

Water Quality and Water Resources: Implications of Changes in Climate and Water Use ...........51

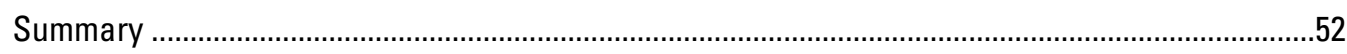

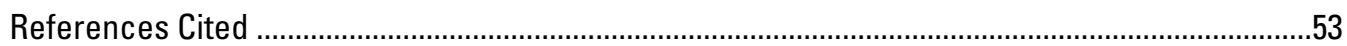

\section{Figures}

1. Map showing upper Rio Hondo Basin study area, Lincoln County, New Mexico ............3

2. Graphs showing $A$, Ruidoso, New Mexico, climate station total annual precipitation, 1942-2013; $B$, Palmer Drought Severity Index, New Mexico Climate Division 6, 1940-2013; and C, Rio Ruidoso at Hollywood, N. Mex., annual mean streamflow, 1954-2013

3. Graphs showing $A$, Ruidoso, New Mexico, climate station average monthly precipitation, 1942-2013; B, Sierra Blanca, New Mexico, SNOpack TELemetry (SNOTEL) climate station average median monthly snow-water equivalent, 2002-10; and C, Rio Ruidoso at Hollywood, N. Mex., average monthly streamflow, 1954-2013 
4. Graph showing average total annual and average total summer (JuneSeptember) precipitation at the Ruidoso, New Mexico, precipitation station (CL1) and maximum snow-water equivalent at the Sierra Blanca SNOpack TELemetry (SNOTEL) station (CL2), Sierra Blanca, N. Mex., 2010-13

5. Graphs showing $A$, Palmer Drought Severity Index, New Mexico Climate Division 6, 2010-13; and B, Extent of drought across New Mexico from the U.S. Drought Monitor, 2010-13

6. Maps showing Little Bear Fire burn area and $A, 37$ groundwater wells in which groundwater-level measurements were made approximately bimonthly between 2010 and 2013; and B, water-quality sampling locations in the upper Rio Hondo Basin, Lincoln County, New Mexico

7. Graph showing daily mean streamflow for Rio Ruidoso at Hollywood, New Mexico (08387000; S6), January 1, 2012-December 31, 2013, and water-quality sampling dates, upper Rio Hondo Basin, Lincoln County, N. Mex.

8. Graphs showing daily mean streamflow for 2010-13 and selected daily statistics at $A$, Rio Ruidoso at Hollywood, New Mexico (08387000; S6); and $B$, Eagle Creek below Southfork near Alto, N. Mex. (08387000; S9), streamflow-gaging stations

9. Graphs showing relation between Rio Ruidoso at Hollywood, New Mexico (08387000; S6) streamflow-gaging station annual mean streamflow and $A$, Ruidoso, New Mexico, climate station total annual precipitation; and $B$, Palmer Drought Severity Index, New Mexico Climate Division 6, 1954-2013

10. Map showing water-level changes in 37 wells from 2010 to 2013, upper Rio Hondo Basin, Lincoln County, New Mexico

11. Normalized hydrographs of selected wells in the $A$, Rio Ruidoso watershed; and $B$, the Rio Bonito watershed from 2010 to 2013, upper Rio Hondo Basin, Lincoln County, New Mexico

12. Hydrographs of wells with continuous water-level recorders in the upper Rio Hondo Basin, Lincoln County, New Mexico

13. Graphs showing $A$, Stable isotopes deuterium $(\delta D)$ and oxygen-18 $\left(\delta^{18} 0\right)$ expressed as the deviation $(\delta)$, in parts per thousand, from Standard Mean Ocean Water; and $B$, Deuterium values with respect to site land-surface elevation in surface-water, groundwater, and spring samples collected in the upper Rio Hondo Basin, Lincoln County, New Mexico

14. Graphs showing specific conductance according to approximate river mile in the $A$, Rio Ruidoso and $B$, Rio Bonito, upper Rio Hondo Basin, Lincoln County, New Mexico

15. Trilinear diagram showing hydrochemical-facies classification of major-ion chemistry of surface water in the upper Rio Hondo Basin, Lincoln County, New Mexico, sampled from 1955 to 1957 and in 2012 and 2013

16. Graphs showing concentrations of selected water-quality constituents at Eagle Creek, Rio Bonito, and Rio Ruidoso, 2012-13, upper Rio Hondo Basin, Lincoln County, New Mexico

17. Trilinear diagram showing hydrochemical-facies classification of major-ion chemistry of groundwater in the upper Rio Hondo Basin, Lincoln County, New Mexico, sampled from 1926 to 1957 and 2013 


\section{Tables}

1. Climate station and streamflow-gaging station information for stations used in analysis, upper Rio Hondo Basin, Lincoln County, New Mexico ....................................

2. Categories and descriptions of drought severity for the Palmer Drought Severity Index and the U.S. Drought Monitor per http://droughtmonitor.unl.edu/ ........................8

3. Groundwater wells and water-level changes from 2010 to 2013, upper Rio Hondo Basin, Lincoln County, New Mexico

4. Water-quality and isotope sampling sites, upper Rio Hondo Basin, Lincoln County, New Mexico

5. Results from field blanks and replicate water-quality samples collected in the upper Rio Hondo Basin, Lincoln County, New Mexico

6. Water-quality data for surface-water and groundwater sites sampled in the upper Rio Hondo Basin, Lincoln County, New Mexico

7. Isotope data for sites sampled in the upper Rio Hondo Basin, Lincoln County, New Mexico

8. Median concentrations of selected water-quality constituents from filtered samples collected in the upper Rio Hondo Basin, Lincoln County, New Mexico

9. Number of surface-water and groundwater quality samples exceeding U.S. Environmental Protection Agency National Secondary Drinking Water Regulation standards in the upper Rio Hondo Basin, Lincoln County, New Mexico

\section{Conversion Factors}

Inch/Pound to International System of Units

\begin{tabular}{lcl}
\hline \multicolumn{1}{c}{ Multiply } & By & \multicolumn{1}{c}{ To obtain } \\
\hline inch (in.) & Length & \\
inch (in.) & 2.54 & centimeter $(\mathrm{cm})$ \\
foot (ft) & 25.4 & millimeter $(\mathrm{mm})$ \\
mile (mi) & 0.3048 & meter $(\mathrm{m})$ \\
\hline & 1.609 & kilometer $(\mathrm{km})$ \\
\hline acre & Area & \\
acre & 4,047 & square meter $\left(\mathrm{m}^{2}\right)$ \\
square mile $\left(\mathrm{mi}^{2}\right)$ & 0.004047 & square kilometer $\left(\mathrm{km}^{2}\right)$ \\
\hline & 2.590 & square kilometer $\left(\mathrm{km}^{2}\right)$ \\
\hline cubic foot per second $\left(\mathrm{ft}^{3} / \mathrm{s}\right)$ & Flow rate & \\
inch per year $(\mathrm{in} / \mathrm{yr})$ & 0.02832 & cubic meter per second $\left(\mathrm{m}^{3} / \mathrm{s}\right)$ \\
\hline
\end{tabular}

Temperature in degrees Celsius $\left({ }^{\circ} \mathrm{C}\right)$ may be converted to degrees Fahrenheit $\left({ }^{\circ} \mathrm{F}\right)$ as ${ }^{\circ} \mathrm{F}=\left(1.8 x^{\circ} \mathrm{C}\right)+32$ 


\section{Datum}

Vertical coordinate information is referenced to the North American Vertical Datum of 1988 (NAVD 88)

Horizontal coordinate information is referenced to the North American Datum of 1983 (NAD 83)

Elevation, as used in this report, refers to distance above the vertical datum.

\section{Supplemental Information}

Specific conductance is given in microsiemens per centimeter at 25 degrees Celsius $(\mu \mathrm{S} / \mathrm{cm}$ at $\left.25^{\circ} \mathrm{C}\right)$.

Concentrations of chemical constituents in water are given either in milligrams per liter (mg/L) or micrograms per liter $(\mu \mathrm{g} / \mathrm{L})$.

A water year is the 12-month period from 0ctober 1 through September 30 designated by the calendar year in which it ends.

\section{Abbreviations}

$\begin{array}{ll}{ }^{13} \mathrm{C} & \text { Carbon-13 } \\ { }^{14} \mathrm{C} & \text { Carbon-14 } \\ \text { CFC } & \text { Chloroflurocarbon } \\ \text { CL1 } & \text { Ruidoso climate station } \\ \text { CL2 } & \text { Sierra Blanca climate station } \\ \delta & \text { Delta } \\ \delta \text { D } & \text { Deuterium } \\ \delta^{18} \mathrm{O} & \text { Oxygen-18 } \\ \text { DO } & \text { Dissolved oxygen } \\ \text { DOC } & \text { Dissolved organic carbon } \\ \text { EPA } & \text { Environmental Protection Agency } \\ \text { E } & \text { Estimated } \\ \text { GMWL } & \text { Global Meteoric Water Line } \\ { }^{3} \mathrm{H} & \text { Tritium } \\ \text { LMWL } & \text { Local Meteoric Water Line } \\ \text { LRL } & \text { Laboratory reporting level } \\ \text { LT-MDL } & \text { Long-term method detection level } \\ \text { NCDC } & \text { National Climatic Data Center } \\ \text { NOAA } & \text { National Oceanic and Atmospheric Administration } \\ \text { NRCS } & \text { National Resources Conservation Service } \\ \text { NSDWR } & \text { National Secondary Drinking Water Regulation } \\ \text { NTRU } & \text { Nephelometric turbidity ratio units } \\ \text { NWIS } & \text { National Water Information System } \\ \text { NWQL } & \text { National Water Quality Laboratory } \\ & \end{array}$




$\begin{array}{ll}\text { PDSI } & \text { Palmer Drought Severity Index } \\ \text { pM } & \text { Percent modern } \\ \text { pmC } & \text { Percent modern carbon } \\ \text { RPD } & \text { Relative percent difference } \\ \text { SMT } & \text { Sacramento Mountains Trend } \\ \text { SNOTEL } & \text { SNOwpack TELemetry } \\ \text { TU } & \text { Tritium units } \\ \text { USGS } & \text { U.S. Geological Survey }\end{array}$

VSMOW Vienna Standard Mean Ocean Water 



\title{
Water Resources During Drought Conditions and Postfire Water Quality in the Upper Rio Hondo Basin, Lincoln County, New Mexico, 2010-13
}

\author{
By Lauren R. Sherson and Steven E. Rice
}

\section{Abstract}

Stakeholders and water-resource managers in Lincoln County, New Mexico, have had long-standing concerns over the impact of population growth and groundwater withdrawals. These concerns have been exacerbated in recent years by extreme drought conditions and two major wildfires in the upper Rio Hondo Basin, located in south-central New Mexico. The U.S. Geological Survey (USGS), in cooperation with Lincoln County, initiated a study in 2006 to assess and characterize water resources in the upper Rio Hondo Basin. Data collected during water years 2010-13 are presented and interpreted in this report. All data presented in this report are described in water years unless stated otherwise.

Annual mean streamflow at the Rio Ruidoso at Hollywood, N. Mex., streamflow-gaging station was less than 50 percent of the average streamflow during 2011-13 and was of similar magnitude to annual mean streamflow values measured during the drought of the 1950s. The first zero-streamflow values for the period of record (1954-2013) were recorded at the Rio Ruidoso at Hollywood, N. Mex., streamflow-gaging station on June 27-29, 2013. The lowest annual mean streamflow on record (1969-80; 1988-2013) occurred in 2011 at the Eagle Creek below South Fork near Alto, N. Mex., streamflow-gaging station, with the station recording zero streamflow for approximately 50 percent of the year.

Discrete and continuous groundwater-level measurements indicated basinwide water-level declines during drought conditions in 2011-13. The average water-level change among 37 wells in which discrete groundwater-level measurements were collected was $-7.6 \mathrm{ft}$ from 2010 to 2013 . The largest water-level declines were observed in the upper reaches of the Rio Bonito and Rio Ruidoso watersheds, and smaller declines were observed in the lower reaches of the watersheds. In general, water-level changes observed during 2010-13 were on the order of decadal-scale changes that previously have been observed in the upper Rio Hondo Basin.

Stable-isotope data indicate that high-elevation winter precipitation generally contributes more to groundwater recharge than summer rains, except when there are large summer recharge events. This implies that little recharge is occurring at the lower elevations in the upper Rio Hondo Basin because these areas receive a smaller amount of total precipitation, receive a smaller proportion of the annual total falling as winter precipitation, and have higher average temperatures that result in more evaporative losses. Groundwater in the upper Rio Hondo Basin is a mix of younger and older water, and recharge likely is occurring primarily at higher elevations but there may be some areas where localized recharge is occurring at lower elevations.

Surface-water- and groundwater-quality results from samples collected in 2012-13 were examined to characterize overall chemistry and were compared to historical waterquality data from streams in the upper Rio Hondo Basin collected during 1926-57. In general, specific conductance showed an increasing trend moving eastward (downstream) through the upper Rio Hondo Basin in surface-water and groundwater samples. Surface-water and groundwater samples appear to have similar overall major-ion chemical characteristics when compared to historical water-quality data. Geology was found to influence the chemical characteristics of surface-water and groundwater samples, with relatively higher concentrations of sulfate occurring in samples collected at lower elevations in the Permian regional aquifer system.

Surface-water sample results also were analyzed to determine differences in unfiltered and filtered water-quality samples of streams in burned and unburned watersheds after the occurrence of the Little Bear Fire in June 2012. Samples were collected after postfire monsoon rain events and during periods of stable hydrologic conditions. The first postfire monsoon rain event in July 2012 generally produced the highest measured concentrations of selected fire-related constituents in unfiltered samples collected in the burned watersheds relative to later samples collected in burned watersheds and all samples collected in the unburned watershed. Monsoon rain events have impacted water quality by delivering larger sediment loads and fire-related constituents into streams in the upper Rio Hondo Basin.

Changes in climate and increased groundwater and surface-water use are likely to affect the availability of water in the upper Rio Hondo Basin. Increased drought probably will increase the potential for wildfires, which can affect downstream water quality and increase flood potential. 
Climate-research predicted decreases in winter precipitation may have an adverse effect on the amount of groundwater recharge that occurs in the upper Rio Hondo Basin, given the predominance of winter precipitation recharge as indicated by the stable isotope results. Decreases in surface-water supplies because of persistent drought conditions and reductions in the quality of water because of the effects of wildfire may lead to a larger reliance on groundwater reserves in the upper Rio Hondo Basin. Decreasing water levels because of increasing groundwater withdrawal could reduce base flows in the Rio Bonito and Rio Ruidoso. Well organized and scientificallysupported regional water-resources management will be necessary for dealing with the likely scenario of increases in demand coupled with decreases in supply in the upper Rio Hondo Basin.

\section{Introduction}

The U.S. Geological Survey (USGS), in cooperation with Lincoln County, initiated a study in 2006 to assess and characterize water resources in the upper Rio Hondo Basin. Stakeholders and water-resource managers have had longstanding concerns over the impact of population growth and groundwater withdrawals. These concerns have been exacerbated by recent drought and wildfire conditions in the upper Rio Hondo Basin.

The upper Rio Hondo Basin, located in south-central New Mexico (fig. 1), experienced extreme drought conditions (National Oceanic and Atmospheric Administration, National Climatic Data Center, 2014b) and two major wildfires from 2011 to 2013. Total annual precipitation at the Ruidoso climate station was measured at a record low of 12.0 inches in 2011 for the period of record 1942-2013. Annual Palmer Drought Severity Index (PDSI) values indicate that the two most extreme years of drought for New Mexico Climate Division 6 , which contains the upper Rio Hondo Basin, occurred in 2011 (ranked 2nd) and 2012 (ranked 1st), with 2013 being the 4th-worst drought based on the period of record (18952013) (National Oceanic and Atmospheric Administration, National Climatic Data Center, 2014b). The 2011 White Fire and the 2012 Little Bear Fire may have occurred because of or been intensified by drought conditions. In April 2011, the White Fire burned approximately 16 square miles $\left(\mathrm{mi}^{2}\right)$ (10,300 acres) near the city of Ruidoso Downs, New Mexico (Southwest Fire Science Consortium, 2013). Approximately one year later, in June 2012, the Little Bear Fire burned approximately $69 \mathrm{mi}^{2}$ (44,300 acres) in the high-elevation forests of the upper Rio Bonito and Eagle Creek watersheds (Snyder and others, 2012). The documentation and analysis of streamflow, groundwater levels, and water quality during and following drought and wildfire conditions are important in future water-resource planning when investigating the effects of climatic extremes on water resources. In addition, investigations into the source and timing of recharge to the upper Rio Hondo Basin may assist water planners and managers in determining how the surface-water and groundwater systems will react to future drought conditions and increased municipal water demands.

\section{Purpose and Scope}

The purpose of this report is to present and interpret water resources and water quality on the basis of streamflow, groundwater-level, isotope, and water-quality data from the upper Rio Hondo Basin in south-central New Mexico collected during water years 2010-13 (a water year is the 12-month period of October 1 through September 30 designated by the calendar year in which it ends). All data presented in this report are described in water years unless stated otherwise. This report documents the extent of the 2011-13 drought, characterizes streamflow conditions and groundwater-level declines from 2010 to 2013, presents interpretations of isotope results from samples collected in 2013 that inform recharge mechanisms, and presents waterquality data collected following the 2012 Little Bear Fire. Streamflow and groundwater-level data are presented from 2010 to 2013, beginning one year prior to the 2011-13 drought, in order to provide a year with more precipitation than average (2010) as a comparison period and create a continuous period of investigation with the previous report associated with this study (Darr and others, 2014), which ended in 2010.

Hydrologic data collected from streamflow-gaging stations and groundwater-monitoring wells are described and compared with historical data in the upper Rio Hondo Basin to assess the effect of drought conditions from 2011 to 2013 on groundwater levels and streamflow. Isotope data were used to interpret regional recharge characteristics and the implications of climate variability on water resources of the upper Rio Hondo Basin. In addition, water-quality results are presented from surface-water samples and groundwater samples collected in calendar years 2012 and 2013. Surfacewater samples were collected at sites located downstream from burned and unburned watersheds.

\section{Description of Study Area}

A detailed description of the upper Rio Hondo Basin (study area) is available in Darr and others (2014) and is summarized here. The upper Rio Hondo Basin is located in south-central New Mexico within Lincoln and Otero Counties (fig. 1). The basin encompasses $585 \mathrm{mi}^{2}$ (374,400 acres) and consists of two primary watersheds of approximately equal area: the Rio Bonito watershed $\left(296 \mathrm{mi}^{2}\right)$ and the Rio Ruidoso watershed (289 $\mathrm{mi}^{2}$ ) (fig. 1). The upper Rio Hondo Basin contains three major reservoirs (fig. 1): Bonito Lake; Alto Reservoir; and Grindstone Reservoir, which provides drinking water to residents of the upper Rio Hondo Basin and an adjoining basin. 


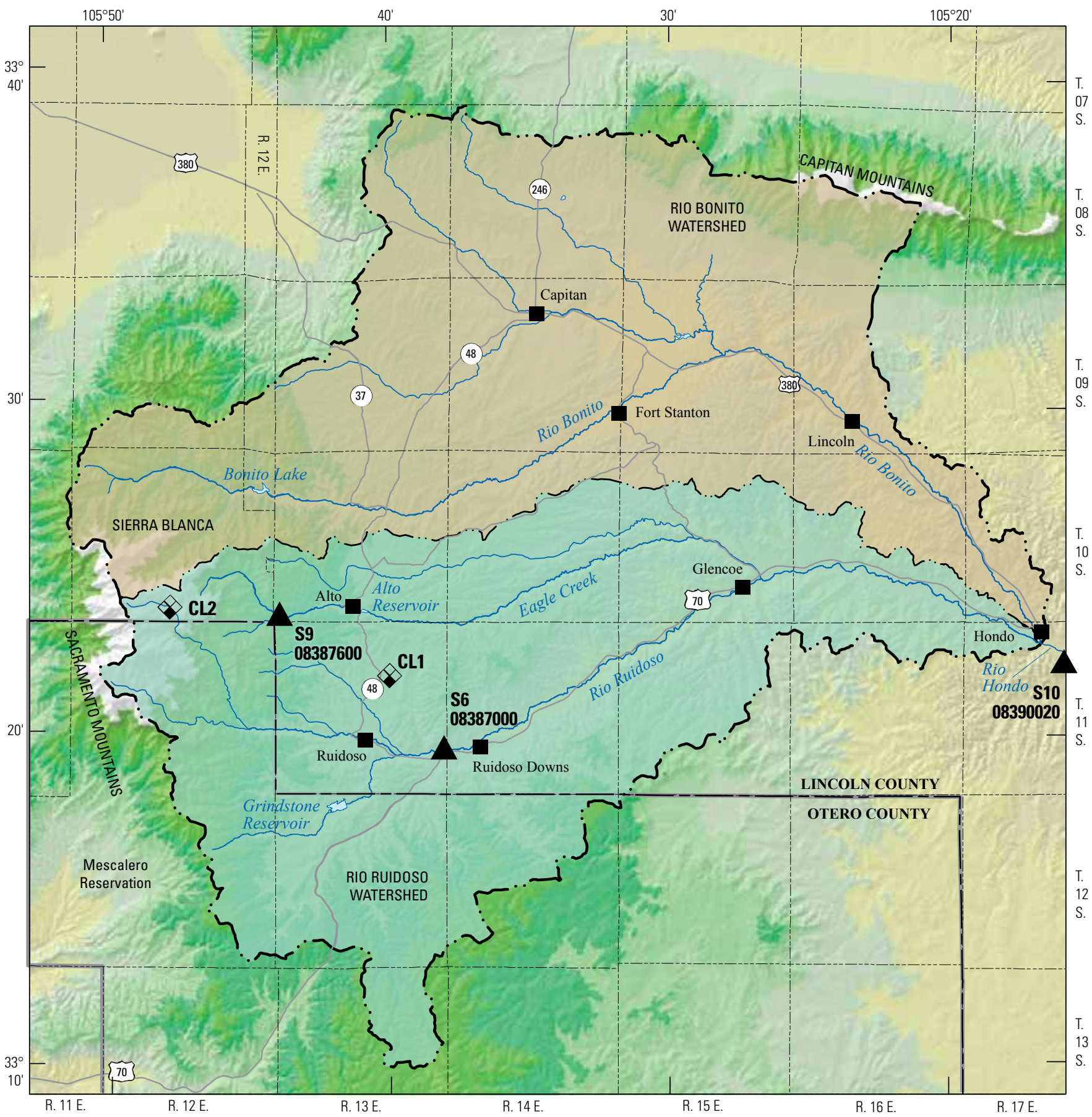

Base from U.S. Geological Survey, 2005, 10-meter Digital Elevation Model data and Bureau of Land Management digital data, 2004, 1:100,000 Universal Transverse Mercator projection, zone 13 North American Datum of 1983 (NAD 83)

EXPLANATION

Elevation, in feet above North American Vertical Datum of 1988 (NAVD 88) 5,000 to 5,700
5,700 to 6,400
6,400 to 7,100
7,100 to 7,800
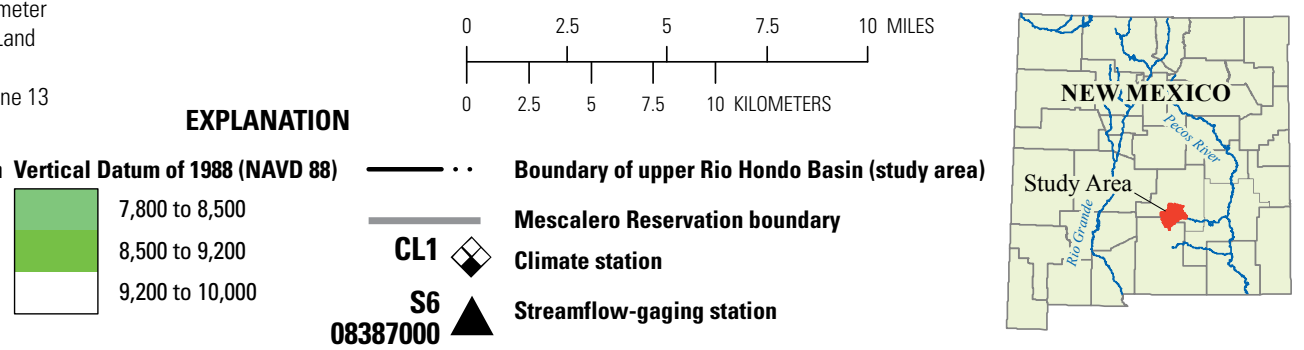

Figure 1. Upper Rio Hondo Basin study area, Lincoln County, New Mexico. 
The elevation change in the upper Rio Hondo Basin is considerable, with the highest point being Sierra Blanca on the western edge of the study area (elevation 12,003 feet [ft]) and the lowest point being at the confluence of the Rio Bonito and Rio Ruidoso near the town of Hondo (elevation $5,185 \mathrm{ft}$ ). Most of the land cover in the study area is piñonjuniper, ponderosa, and mixed conifer forests interspersed with grasslands. Desert grasses, cacti, and shrubs dominate the lower-elevation eastern part of the study area (Larry Cordova, U.S. Forest Service, written commun., 2014).

\section{Hydrogeologic Setting}

The upper Rio Hondo Basin is bounded on the north by the Capitan Mountains and the west and south by the Sacramento Mountains. The study area extends eastward to the confluence of the Rio Bonito and the Rio Ruidoso, which form the Rio Hondo at the eastern boundary of the study area (fig. 1). The Rio Bonito is mostly perennial in its upper reaches and becomes intermittent downstream in the lowerelevation eastern part of the study area. The Rio Ruidoso is perennial for most of its length. Eagle Creek is a major tributary to the Rio Ruidoso and is also largely perennial in its upper reaches but becomes intermittent a short distance downstream (fig. 1).

There are multiple water-bearing geologic units (hydrostratigraphic units) in the upper Rio Hondo Basin, with as many as 12 hydrostratigraphic units serving as productive aquifers (Darr and others, 2014). In general, the primary water-bearing units in the basin are the San Andres Formation and Yeso Formation of Permian age and alluvium of Quaternary age (Mourant, 1963; Thompson, 1964; Newcomer and Shomaker, 1991; Rawling, 2011). Locally, Tertiaryage volcaniclastic rocks can provide substantial quantities of potable water (Matherne and others, 2010). The primary source of recharge to streams and aquifers in the study area is precipitation originating at high elevations in the Sacramento and Capitan Mountains (Darr and others, 2014). Surface water and groundwater generally flow eastward, from high to low elevation, through the upper Rio Hondo Basin.

\section{Precipitation}

Precipitation data were collected from the Ruidoso climate station (CL1) by the National Climatic Data Center (NCDC) of the National Oceanic and Atmospheric Administration (NOAA), and snowpack data were collected from the Sierra Blanca SNOwpack TELemetry (SNOTEL) climate station (CL2) by the National Resources Conservation Service (NRCS) (table 1). The CL1 is located near the city of Ruidoso at an elevation of $6,930 \mathrm{ft}$, and CL2 is located near the western border of the study area in the high-elevation Sacramento Mountains at 10,280 ft (fig. 1).

Table 1. Climate station and streamflow-gaging station information for stations used in analysis, upper Rio Hondo Basin, Lincoln County, New Mexico.

[USGS, U.S. Geological Survey; CL, climate; NA, not applicable; SNOTEL, SNOwpack TELemetry; SW, surface water]

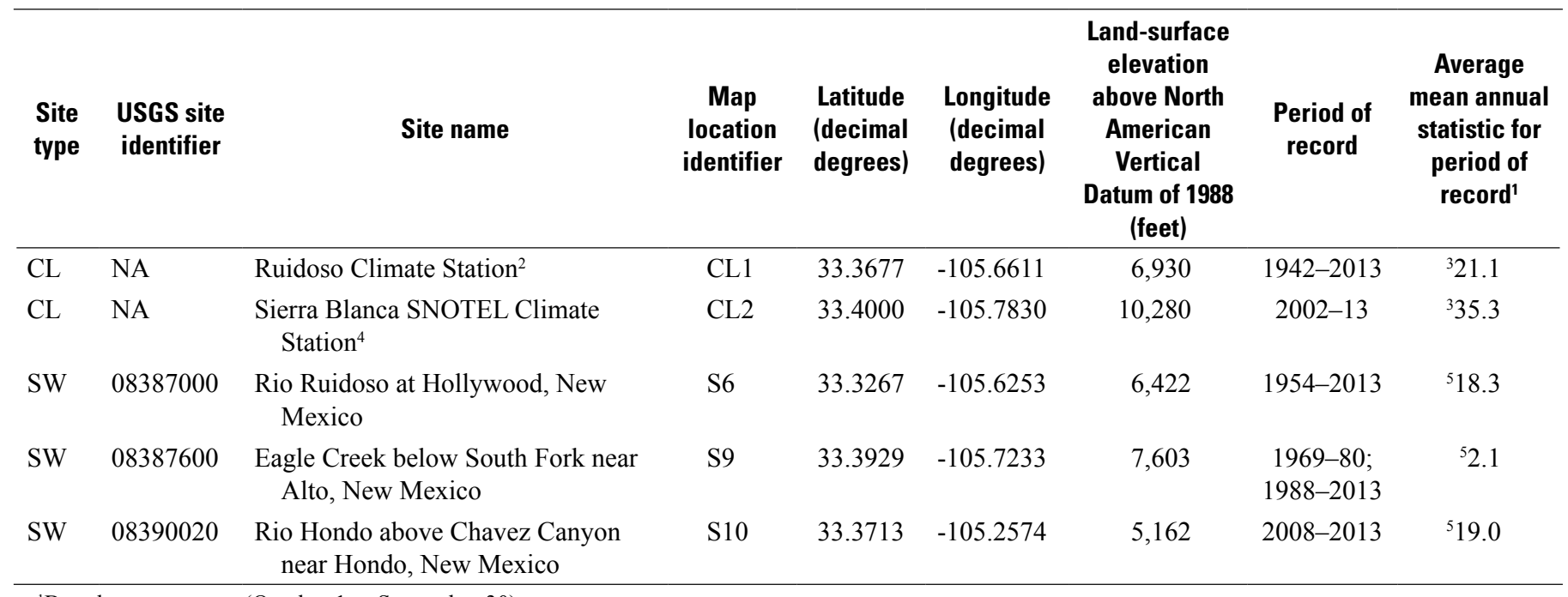

${ }^{1}$ Based on water year (October 1 to September 30).

${ }^{2}$ Operated by the National Climatic Data Center of the National Oceanic and Atmospheric Administration; used Ruidoso2 station from August 1988 to April 1993; years missing more than 2 months of data were excluded from average calculation.

${ }^{3}$ Precipitation, in inches.

${ }^{4}$ Operated by the National Resources Conservation Service.

${ }^{5}$ Streamflow, in cubic feet per second. 
Total annual precipitation varies spatially throughout the study area depending on elevation, ranging from 15 inches per year (in/yr) in the eastern lowland areas and valleys to $40 \mathrm{in} / \mathrm{yr}$ at high elevations (Matherne and others, 2010; Darr and others, 2014). At the CL1 station, average total annual precipitation for the period of record (1942-2013) is 21.1 inches with a range from 12.0 inches in 2011 to 30.4 inches in 1965 (fig. 2A) (National Oceanic and Atmospheric
Administration, National Climatic Data Center, 2014a). Mean-monthly precipitation data indicate that a majority of the precipitation falls during the summer months (June-September) as monsoon storms (fig. 3A). Summer precipitation accounts for an average of 59 percent of the total annual precipitation for the period of record (1942-2013) (fig. $3 A$ ). Data from the CL1 station indicate that greater-thanaverage total annual precipitation occurred in 2010, whereas
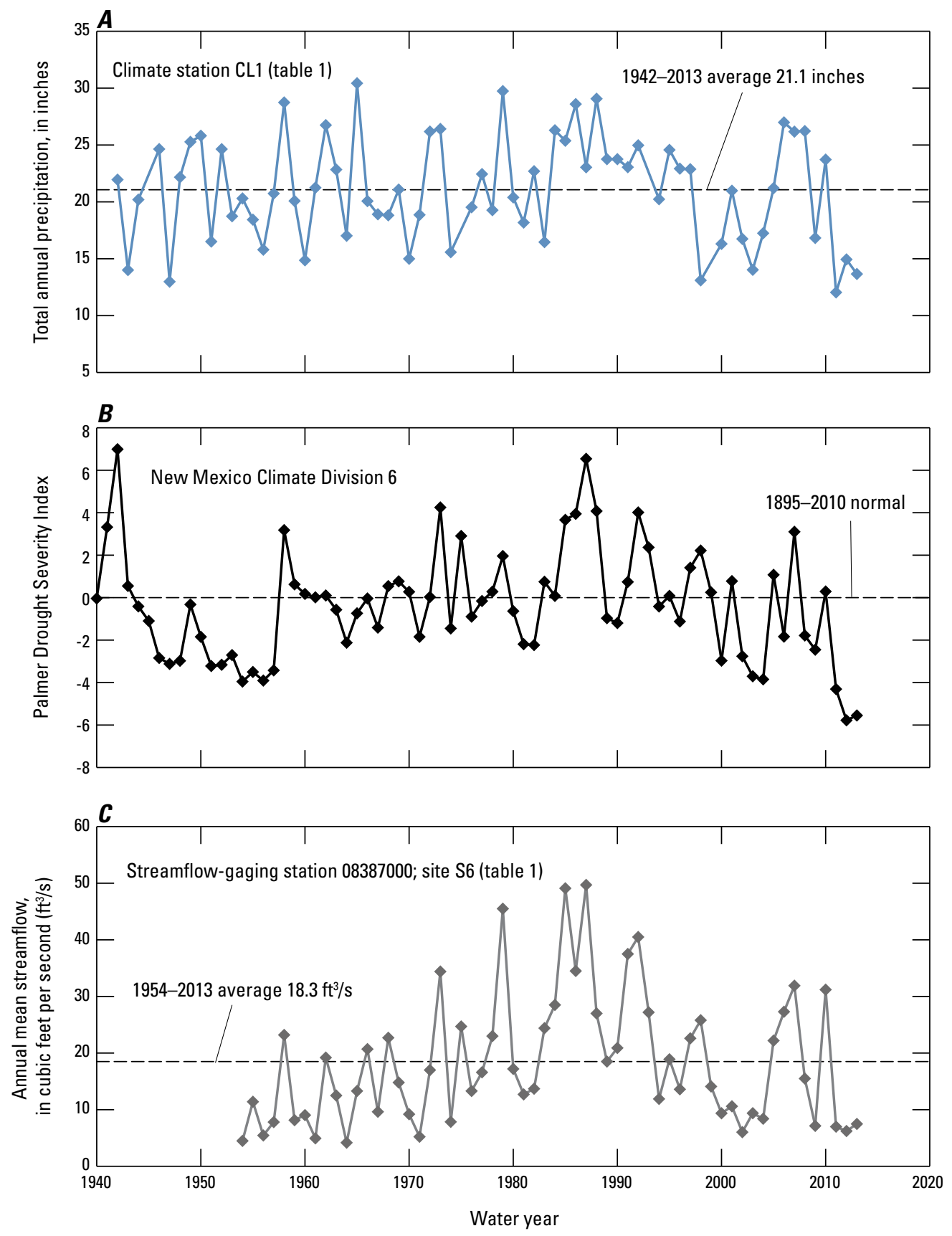

Figure 2. A, Ruidoso, New Mexico, climate station total annual precipitation, 1942-2013; B, Palmer Drought Severity Index, New Mexico Climate Division 6, 1940-2013; and C, Rio Ruidoso at Hollywood, N. Mex., annual mean streamflow, $1954-2013$. 

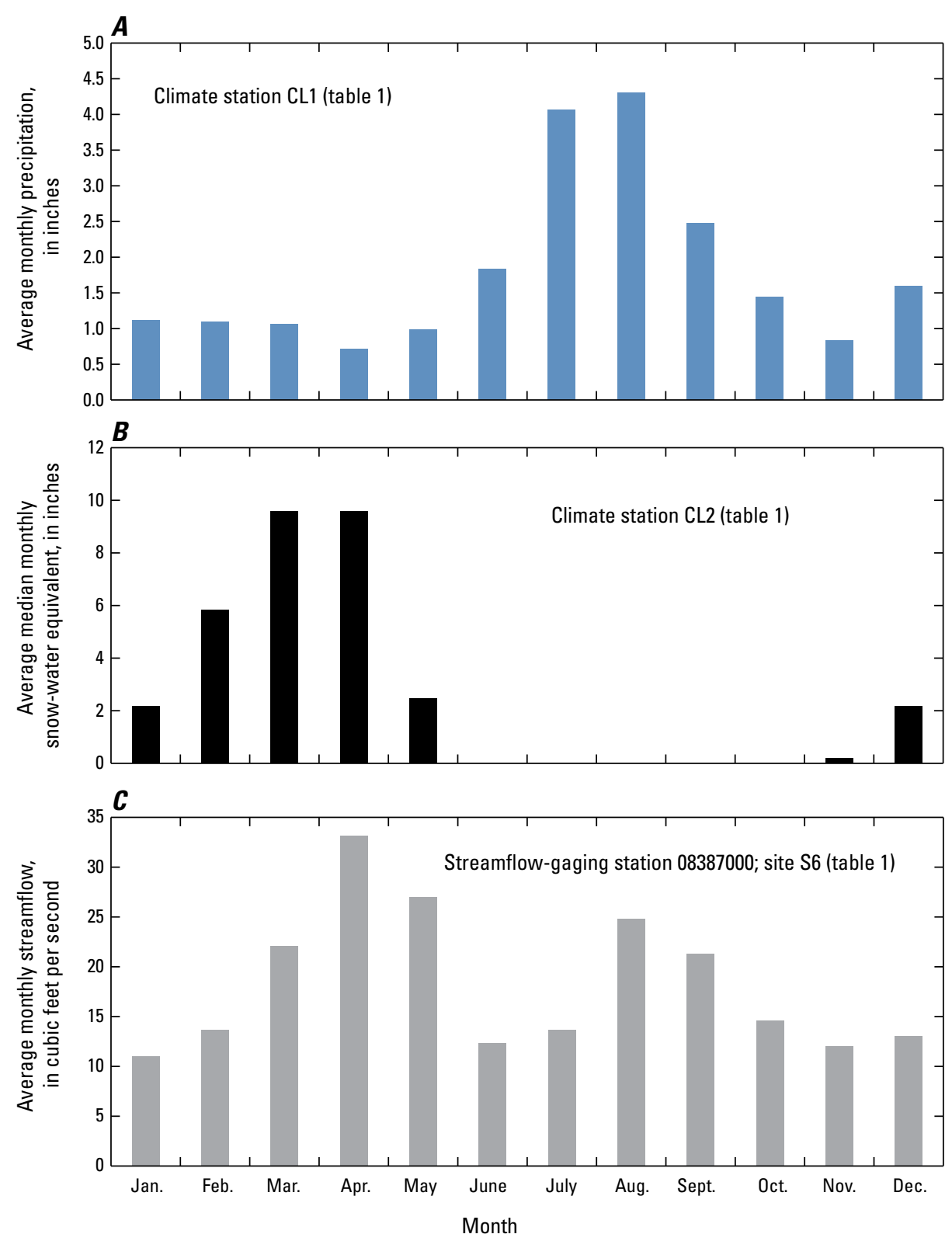

Figure 3. A, Ruidoso, New Mexico, climate station average monthly precipitation, 1942-2013; B, Sierra Blanca, New Mexico, SNOpack TELemetry (SNOTEL) climate station average median monthly snow-water equivalent, 2002-10; and $C$, Rio Ruidoso at Hollywood, N. Mex., average monthly streamflow, 1954-2013.

lower-than-average total annual precipitation occurred in 2011, 2012, and 2013 (fig. 4). Total annual precipitation was 23.7 inches in 2010, 2.6 inches above the average over the period of record. Total annual precipitation was 12.0 inches in 2011 and 13.7 inches in 2013, representing the 1st and 4th, respectively, lowest totals on record at this climate station. Total summer precipitation was below average (12.3 inches) in 2011 (8.9 inches) and 2012 (8.1 inches) (fig. 4).

Despite 2013 receiving 7.4 inches less than the average total annual precipitation at the CL1 station (13.7 inches as opposed to the 21.1-in/yr average) (fig. 4), the area experienced above-average summer precipitation (13.1 inches) as a result of extreme rainfall in August and September 2013. The CL1 station received 5.3 inches of precipitation in August 2013 and an additional 4.1 inches from September 10 to September 17, 2013 (National Oceanic and Atmospheric Administration, National Climatic Data Center, 2014a). The CL2 station also recorded an extreme amount of precipitation during this 8-day period in September (8.4 inches). From 2002 to 2010, the CL2 station averaged 4.0 inches of precipitation for the entire month of September (Natural Resources Conservation Service, 2014). 


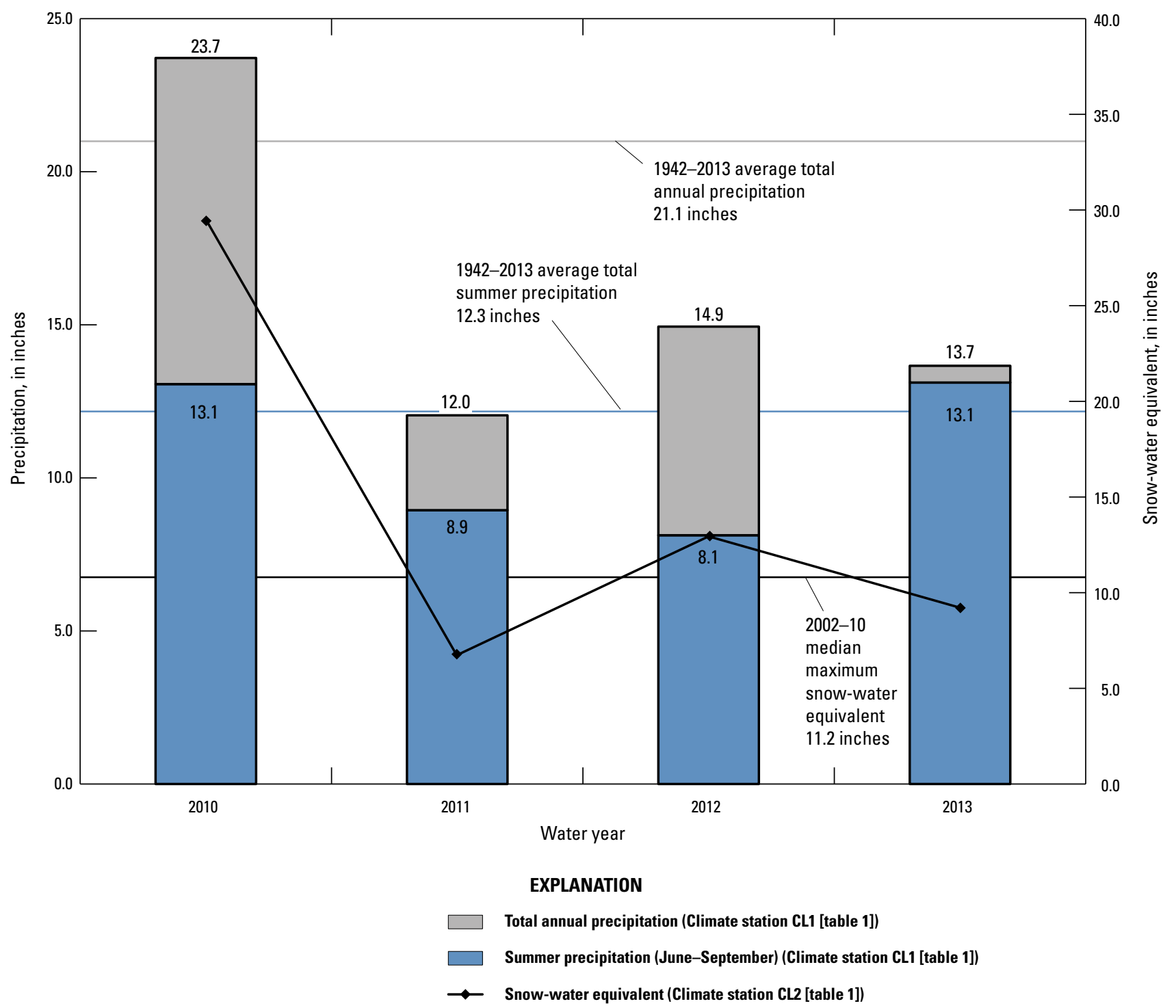

Figure 4. Average total annual and average total summer (June-September) precipitation at the Ruidoso, New Mexico, precipitation station (CL1) and maximum snow-water equivalent at the Sierra Blanca SNOpack TELemetry (SNOTEL) station (CL2), Sierra Blanca, N. Mex., 2010-13.

Median monthly snow-water equivalent for the CL2 station shows that for the period 2002-10, snowpack in the study area typically reaches the maximum snow-water equivalent in February and March, followed by a rapid melt period in April and May (fig. 3B). Maximum snow-water equivalent was greater than the median of 11.2 inches in 2010 (29.4 inches) and 2012 (12.9 inches) but lower-than-average in 2011 (6.7 inches) and 2013 (9.2 inches) (fig. 4).

\section{Drought Conditions}

The extent of the 2011-13 drought is documented regionally by the Palmer Drought Severity Index (PDSI) and statewide by data from the U.S. Drought Monitor (University of Nebraska-Lincoln, 2014) (table 2). The PDSI is a quantitative estimate of drought severity based on the metrics of soil moisture, precipitation, and temperature (Palmer, 1965). Negative PDSI values represent below-normal precipitation, or drought conditions, with values less than -3.99 representing extreme drought (Palmer, 1965) (table 2). New Mexico has eight climatic divisions and the upper Rio Hondo Basin is located in New Mexico Climate Division 6 (Central Highlands) (fig. 5). According to the PDSI, New Mexico Climate Division 6 was classified as undergoing extreme drought from April 2011 to August 2013 (fig. 5A). Annual PDSI rankings for 2011, 2012, and 2013 were 2nd, 1 st, and 4th lowest, respectively, for New Mexico Climate Division 6, based on the period of record 1895-2013. The PDSI for New Mexico Climate Division 6 from 1940 through 2013 is shown in figure 2B. During this period (1940-2013), 
Table 2. Categories and descriptions of drought severity for the Palmer Drought Severity Index and the U.S. Drought Monitor per http://droughtmonitor.unl.edu/.

[Palmer Drought Severity Index from Palmer, 1965; Drought Monitor from University of Nebraska-Lincoln, 2014]

\begin{tabular}{cccccl}
\hline \multicolumn{2}{c}{ Palmer Drought Severity Index } & & \multicolumn{2}{c}{ Drought Monitor } \\
\cline { 1 - 1 } \cline { 5 - 6 } Category & \multicolumn{1}{c}{ Description } & & Category & \multicolumn{1}{c}{ Description } \\
\hline-0.50 to -0.99 & Incipient drought & & D0 & Abnormally dry \\
-1.00 to -1.99 & Mild drought & & D1 & Moderate drought \\
-2.00 to -2.99 & Moderate drought & & D2 & Severe drought \\
-3.00 to -3.99 & Severe drought & & D3 & Extreme drought \\
Less than -3.99 & Extreme drought & & D4 & Exceptional drought \\
\hline
\end{tabular}

the only years in which annual PDSI values dropped below -3.99 (extreme drought conditions) were 2011, 2012, and 2013 (National Oceanic and Atmospheric Administration, National Climatic Data Center, 2014b).

Drought conditions during the study period were not localized to the study area but extended regionally across New Mexico and the entire Southwest. Figure $5 B$ shows the extent of the 2011-13 drought across New Mexico according to data from the U.S. Drought Monitor (University of Nebraska-Lincoln, 2014). Drought monitor categories and the equivalent PDSI categories are shown in table 2. On January 1, 2011, about 90 percent of New Mexico was classified as being abnormally dry or in a moderate drought, but none of the State was considered to be in severe to exceptional drought (fig. 5B). By July 1, 2011, over 90 percent of New Mexico was in a severe to exceptional drought. Although 2012 exhibited lower drought severity, according to the U.S. Drought Monitor, nearly all of the State exhibited drought conditions. The summer of 2013 exhibited a similar pattern of drought severity to the summer of 2011, with over 90 percent of New Mexico in severe to exceptional drought. The U.S. Drought Monitor data and PDSI values indicate that in September 2013 drought conditions improved slightly, likely because of extreme rainfall events in the region. According to the PDSI, drought conditions for New Mexico Climate Division 6 transitioned from extreme to moderate or mild for the remainder of the calendar year (National Oceanic and Atmospheric Administration, National Climatic Data Center, 2014b) (fig. 5A; table 2).

\section{Wildfire}

Three consecutive years of extreme drought in the upper Rio Hondo Basin likely contributed to the occurrence or intensity of two wildfires during the study period. In April 2011, the White Fire burned approximately $16 \mathrm{mi}^{2}$ (10,300 acres) near the city of Ruidoso Downs, N. Mex., in the lower reaches of the Rio Ruidoso watershed (fig. 6). Burn severity was high or moderate on 71 percent of the burn area and low or unburned on 29 percent of the burn area (Southwest Fire Science Consortium, 2013). Although the White Fire occurred during the study period, the focus of this report is on the effects of the Little Bear Fire because of its larger size and the timing of water-quality sampling. In June 2012, the Little Bear Fire burned approximately $69 \mathrm{mi}^{2}$ (44,300 acres) in the high-elevation forests of the Rio Bonito and Rio Ruidoso watersheds (fig. 6) (Snyder and others, 2012). The Little Bear Fire originated on the northeastern flank of Sierra Blanca and spread rapidly to the north and east, destroying 254 structures. Burn severity was high or moderate on 53 percent of the burn area and low or unburned to very low on 47 percent of the burn area (Snyder and others, 2012). The Little Bear Fire burned 19 percent of the Rio Bonito watershed $\left(55 \mathrm{mi}^{2}\right)$ and 5 percent of the Rio Ruidoso watershed $\left(14 \mathrm{mi}^{2}\right)$. In the Rio Ruidoso watershed, most of the burned area was located within the Eagle Creek watershed, with a small part (less than $3 \mathrm{mi}^{2}$ or less than 1 percent) located outside the Eagle Creek watershed. Overall, approximately 12 percent of the upper Rio Hondo Basin was burned during the Little Bear Fire (fig. 6), but the burned area is located in the region of the watershed that receives the most rainfall (Darr and others, 2014).

\section{Methods}

\section{Streamflow Measurements}

Streamflow data were collected from two USGS streamflow-gaging stations in the upper Rio Hondo Basin, Rio Ruidoso at Hollywood (08387000; site S6) and Eagle Creek below South Fork near Alto (08387600; site S9) (fig. 1; table 1). Stream stages are recorded at 15-minute intervals and transmitted to the USGS National Water Information System (NWIS) database and reported as streamflow. The streamflowgaging station at Rio Ruidoso at Hollywood (site S6), located between Ruidoso and Ruidoso Downs (fig. 1), has been operated by the USGS continuously from 1954 through present (2013) and has the longest record of any site in the study area (fig. 2C). The drainage area upstream from the streamflowgaging station is approximately $120 \mathrm{mi}^{2}$. The streamflow-gaging station at Eagle Creek below South Fork near Alto (site S9) has been operated by the USGS during two periods-1969-80 and 1988- present (2013). It is located 2.6 miles west of Alto, N. Mex. (fig. 1). The drainage area upstream from the streamflowgaging station is approximately $8.1 \mathrm{mi}^{2}$. Several other streamflow-gaging stations have been operated in the past in the upper Rio Hondo Basin (Darr and others, 2014), but a longterm record of streamflow on the Rio Bonito does not exist for the study period described in this report (2010-13). Streamflow leaving the study area has been measured from 2008 to present (2013) by the streamflow-gaging station at Rio Hondo above Chavez Canyon near Hondo, N. Mex. (08390020; site S10) (fig. 1; table 1). Streamflow data for USGS streamflow-gaging stations are available in the NWIS database (U.S. Geological Survey, 2014). 


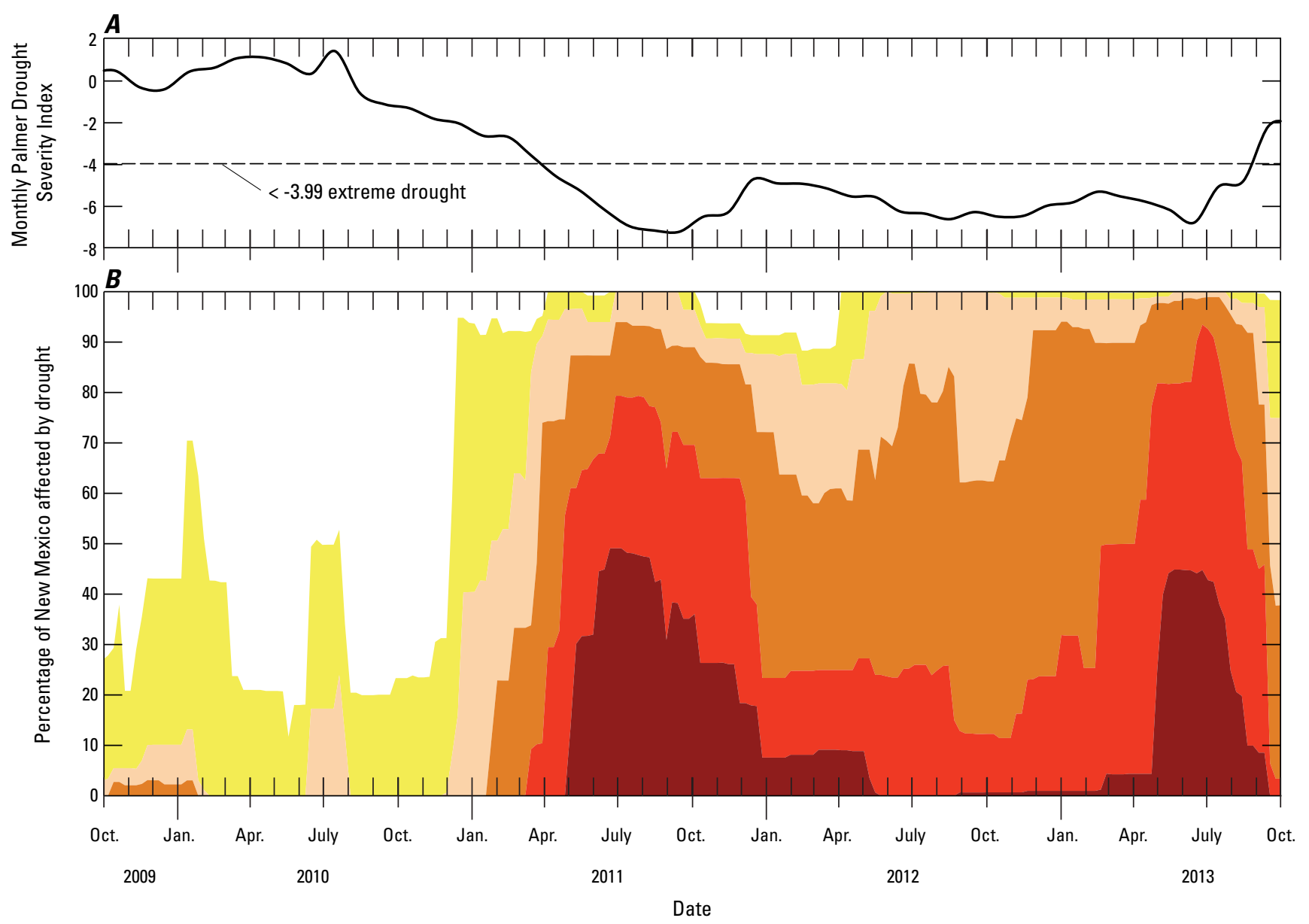

\section{EXPLANATION}

Drought severity

$\square$ D0 - Abnormally dry
$\square$ D1 - Moderate drought
$\square$ D2 - Severe drought
$\square$ D3 - Extreme drought
$\square$ D4 - Exceptional drought

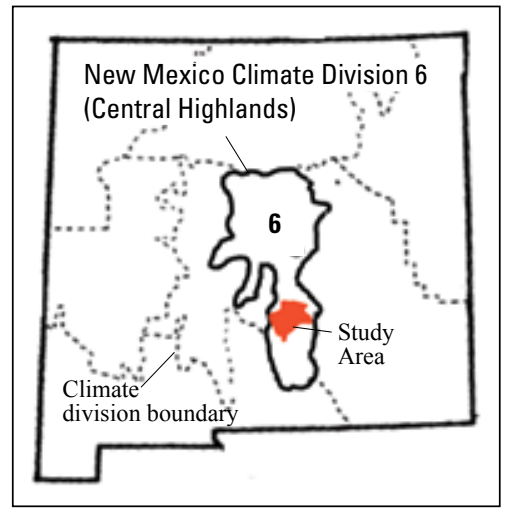

Figure 5. A, Palmer Drought Severity Index, New Mexico Climate Division 6, 2010-13; and B, Extent of drought across New Mexico from the U.S. Drought Monitor (University of Nebraska-Lincoln, 2014), 2010-13. 


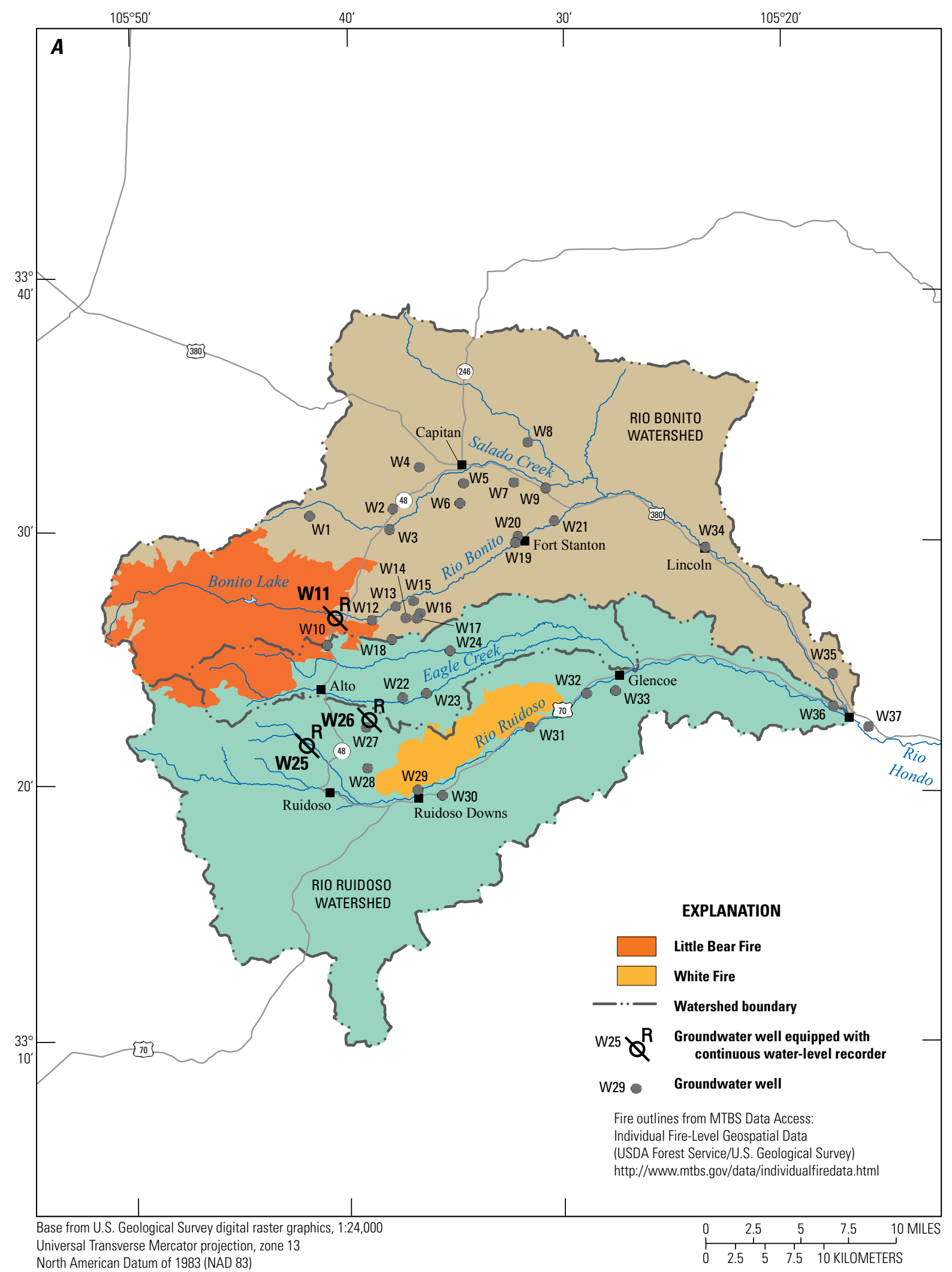

Figure 6. Little Bear Fire burn area and $A, 37$ groundwater wells in which groundwater-level measurements were made approximately bimonthly between 2010 and 2013; and B, water-quality sampling locations in the upper Rio Hondo Basin, Lincoln County, New Mexico. 


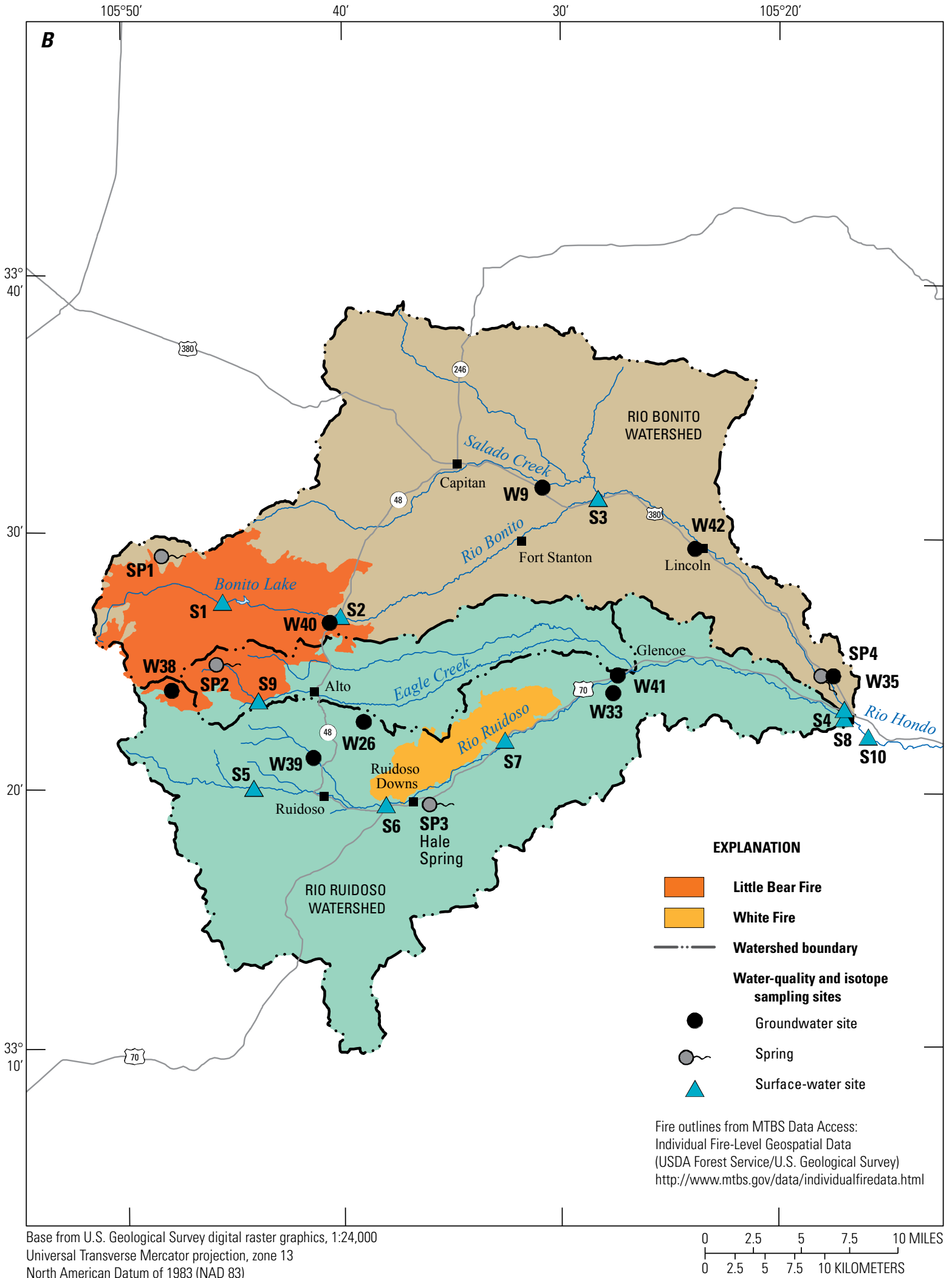

Figure 6. Little Bear Fire burn area and $A, 37$ groundwater wells in which groundwater-level measurements were made approximately bimonthly between 2010 and 2013; and B, water-quality sampling locations in the upper Rio Hondo Basin, Lincoln County, New Mexico.-Continued 


\section{Groundwater-Level Measurements}

Groundwater-level measurements, reported as depth to water ( $\mathrm{ft}$ ) below the land surface, were made approximately bimonthly (once every 2 months) in 37 wells between 2010 and 2013 (fig. 6 A; table 3). Groundwater levels were measured using a steel tape graduated in hundredths of a foot; multiple measurements were made to confirm readings to within 0.02 $\mathrm{ft}$ (Cunningham and Schalk, 2011a). Data were reviewed and entered into the USGS NWIS database (U.S. Geological Survey, 2014). If a well was being pumped at the time of a site visit, the groundwater-level measurement was disregarded for analysis in this report. Groundwater levels were normalized to a common scale (the mean) for the study period (201013) to allow comparison of datasets with a wide range of groundwater-level values on the same plot using the equation:

$$
d_{i}=y_{i}-y
$$

where

$$
\begin{array}{ll}
d_{i} & \text { is the sample deviation of } \mathrm{I} \\
y_{i} & \text { is the sample, and } \\
y & \text { is the mean of the number of samples. }
\end{array}
$$

Increases or decreases in groundwater levels collected during 2010-13 were determined by calculating the difference in water levels from September 2009 to September 2013. The water levels collected nearest to September 2009 and last measured before September 2013 were selected for this calculation. Water levels in September and November 2013 may have been influenced by extreme rainfall events and thus were excluded from this calculation.

Of the 37 wells measured on a bimonthly basis, 3 were also equipped with continuous water-level recorders (wells W11, W25, and W26) (fig. 6A; table 3). The continuous water-level recorders were pressure transducers with internal dataloggers recording at 1-hour intervals that were downloaded and checked every 2-4 months, and data were transferred to the USGS NWIS database (U.S. Geological Survey, 2014). The continuous water-level data were verified and corrected when necessary to steel and electric tape measurements (Cunningham and Schalk, 2011b).

\section{Determination of Recharge Mechanisms Using Isotopes}

\section{Stable Isotopes}

The stable isotopes of hydrogen (deuterium $\left.{ }^{\mathrm{D}}\right]$ ) and oxygen (oxygen-18 $\left[{ }^{18} \mathrm{O}\right]$ ) are ubiquitous in the oceans, atmosphere, precipitation, and surface and groundwater. The isotopes behave conservatively and predictably, making them useful in hydrologic investigations (Kendall and McDonnell, 1998). The predictable signatures and behaviors of these isotopes make them particularly valuable in areas with distinct seasonal precipitation patterns and large variations in annual temperature, such as those of the upper Rio Hondo Basin.
Stable isotope compositions of waters are expressed as a deviation (delta $[\delta]$ ) in parts per thousand (per mil) from a known baseline standard, the Vienna Standard Mean Ocean Water (VSMOW) of Craig (1961), and are presented as $\delta \mathrm{D}$ and $\delta^{18} \mathrm{O}$, for deuterium and oxygen-18, respectively. To better understand how $\delta^{\mathrm{D}}$ and $\delta^{18} \mathrm{O}$ relate to one another and patterns of precipitation, values are plotted against known linear relations of stable isotope composition including the Global Meteoric Water Line (GMWL; Craig, 1961) as well as local meteoric water lines (LMWL) created from local and regional datasets (Newton and others, 2012).

In general, more positive values (enriched/heavier water) are indicative of precipitation in warmer regions, during summer, or at lower elevations. More negative values (depleted/lighter water) are indicative of precipitation in colder regions, during winter, or at higher elevations. Evaporation is an important factor in stable isotope composition, especially in arid and semiarid environments. In areas with lower humidities, the remaining water after evaporation of precipitation will be more enriched, resulting in a deviation from the meteoric water line along a trend with a lower slope (Clark and Fritz, 1997). Other factors affecting stable isotope composition of precipitation include storm track and precipitation amount (rainout). These factors can help constrain the source and behavior of the water that recharges the aquifers in the study area.

Stable-isotope samples were collected from 7 surfacewater sites, 9 groundwater wells, and 4 springs (table 4). Samples for stable isotopes of hydrogen and oxygen were collected without filtering or preservation and were sent to the USGS Reston Stable Isotope Laboratory in Reston, Virginia, for mass spectrometric analysis (Révész and Coplen 2008a, b).

\section{Radioisotopes}

The radioisotopes of hydrogen (tritium $\left[{ }^{3} \mathrm{H}\right]$ ) and carbon-14 $\left({ }^{14} \mathrm{C}\right)$ are used to determine approximate groundwater age, groundwater flow paths, and aquifer mixing. Tritium is a short-lived isotope of hydrogen that has a halflife of 12.33 years (Unterweger and Lucas, 2000), making it useful for the dating of young water (recharged since about 1950). Tritium is produced naturally from the bombardment of nitrogen by cosmic radiation in the upper atmosphere (Clark and Fritz, 1997), where it becomes incorporated into water molecules that fall to the land surface as precipitation. Because aboveground testing of nuclear weapons introduced large quantities of ${ }^{3} \mathrm{H}$ into the atmosphere in the 1950s and $1960 \mathrm{~s},{ }^{3} \mathrm{H}$ is a particularly useful environmental tracer of groundwater recharge occurring during this time period. Carbon, on the other hand, has a half-life of 5,730 years, making it useful for the dating of older water. Like ${ }^{3} \mathrm{H},{ }^{14} \mathrm{C}$ is formed naturally in the upper atmosphere and is quickly oxidized into carbon dioxide, which mixes into the lower atmosphere and becomes incorporated into the biologic and hydrologic cycles. Concentrations of ${ }^{14} \mathrm{C}$ for age dating are measured for dissolved inorganic carbon in the water and are referenced against a known international standard (Clark and Fritz, 1997). 
Table 3. Groundwater wells and water-level changes from 2010 to 2013, upper Rio Hondo Basin, Lincoln County, New Mexico.

[USGS, U.S. Geological Survey; mm, month; dd, day; yyyy, year]

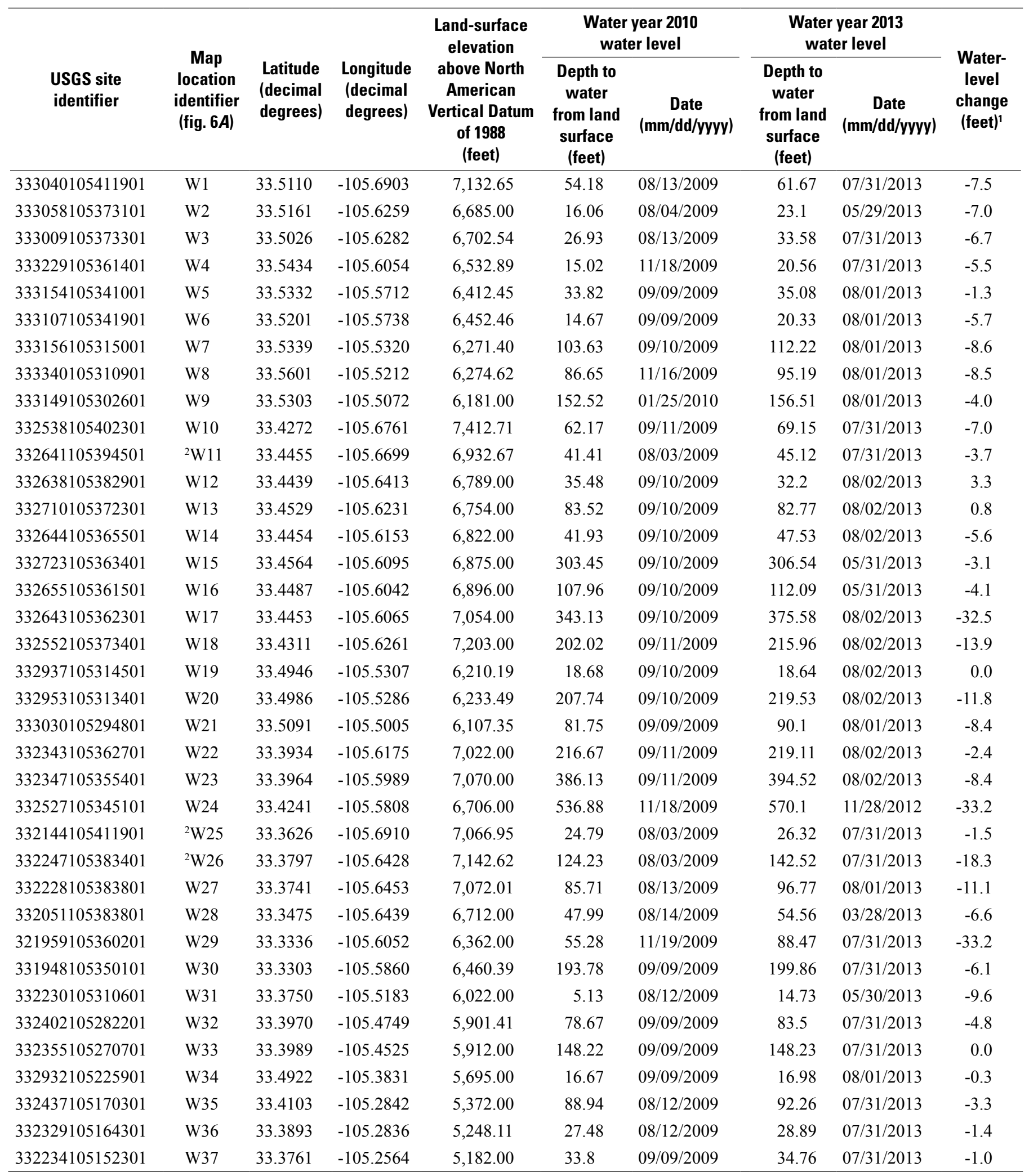

${ }^{1}$ Negative value signifies a decline.

${ }^{2}$ Equipped with continuous water-level recorder. 
Table 4. Water-quality and isotope sampling sites, upper Rio Hondo Basin, Lincoln County, New Mexico.

[USGS, U.S. Geological Survey; mm, month; dd, day; yyyy, year; SW, surface water; Y, yes; NA, not applicable; N, no; SP, spring; GW, groundwater]

\begin{tabular}{|c|c|c|c|c|c|c|c|c|c|c|c|}
\hline $\begin{array}{l}\text { Site } \\
\text { type }\end{array}$ & $\begin{array}{l}\text { USGS site } \\
\text { identifier }\end{array}$ & $\begin{array}{c}\text { Map } \\
\text { location } \\
\text { identi- } \\
\text { fier } \\
\text { (fig. 6) }\end{array}$ & $\begin{array}{l}\text { Watershed } \\
\text { name }\end{array}$ & $\begin{array}{c}\text { Burned or } \\
\text { unburned } \\
\text { water- } \\
\text { shed }\end{array}$ & Latitude & Longitude & $\begin{array}{c}\text { Land-surface } \\
\text { elevation } \\
\text { above North } \\
\text { American } \\
\text { Vertical } \\
\text { Datum of } 1988 \\
\text { (feet) }\end{array}$ & $\begin{array}{c}\text { Sample } \\
\text { dates } \\
\text { (mm/dd/yyyy) }\end{array}$ & $\begin{array}{c}\text { Sam- } \\
\text { pled } \\
\text { for } \\
\text { water } \\
\text { quality }\end{array}$ & $\begin{array}{c}\text { Sam- } \\
\text { pled } \\
\text { for } \\
\text { isotopes }\end{array}$ & $\begin{array}{c}\text { Major } \\
\text { geologic } \\
\text { units }\end{array}$ \\
\hline \multicolumn{12}{|c|}{ Surface water } \\
\hline SW & 332720105450410 & $\mathrm{~S} 1$ & Rio Bonito & Burned & 33.4556 & -105.7511 & 7,540 & $\begin{array}{c}07 / 11 / 2012,04 / 04 / 2013, \\
07 / 22 / 2013,11 / 04 / 2013\end{array}$ & $\mathrm{Y}$ & $\mathrm{Y}$ & NA \\
\hline SW & 08388500 & $\mathrm{~S} 2$ & Rio Bonito & Burned & 33.4472 & -105.6611 & 6,582 & $\begin{array}{r}07 / 11 / 2012,04 / 04 / 2013 \\
07 / 22 / 2013,11 / 05 / 2013\end{array}$ & $\mathrm{Y}$ & Y & NA \\
\hline SW & 08389055 & S3 & Rio Bonito & Burned & 33.5236 & -105.4644 & 5,954 & $07 / 12 / 2012$ & $\mathrm{Y}$ & $\mathrm{N}$ & NA \\
\hline SW & 08389500 & $\mathrm{~S} 4$ & Rio Bonito & Burned & 33.3889 & -105.2756 & 5,207 & $\begin{array}{r}07 / 11 / 2012,04 / 03 / 2013 \\
07 / 23 / 2013,11 / 06 / 2013\end{array}$ & $\mathrm{Y}$ & $\mathrm{Y}$ & NA \\
\hline SW & 08386505 & S5 & Rio Ruidoso & Unburned & 33.3365 & -105.7263 & 7,163 & $\begin{array}{l}07 / 12 / 2012,04 / 02 / 2013, \\
11 / 05 / 2013\end{array}$ & $\mathrm{Y}$ & $\mathrm{Y}$ & NA \\
\hline SW & 08387000 & S6 & Rio Ruidoso & Unburned & 33.3267 & -105.6253 & 6,422 & $\begin{array}{l}\text { 07/11/2012, 04/02/2013, } \\
11 / 05 / 2013\end{array}$ & $\mathrm{Y}$ & $\mathrm{Y}$ & NA \\
\hline SW & 332206105320510 & S7 & Rio Ruidoso & Unburned & 33.3684 & -105.5348 & 6,080 & $\begin{array}{l}\text { 07/11/2012, 04/02/2013, } \\
11 / 05 / 2013\end{array}$ & $\mathrm{Y}$ & $\mathrm{Y}$ & NA \\
\hline SW & 08388000 & S8 & Rio Ruidoso & $\begin{array}{l}\text { Partially } \\
\text { burned }\end{array}$ & 33.3833 & -105.2756 & 5,184 & $\begin{array}{l}07 / 11 / 2012,04 / 03 / 2013, \\
11 / 06 / 2013\end{array}$ & $\mathrm{Y}$ & $\mathrm{Y}$ & NA \\
\hline SW & 08387600 & S9 & Rio Ruidoso & Burned & 33.3929 & -105.7233 & 7,603 & $07 / 11 / 2012,07 / 22 / 2013$ & $\mathrm{Y}$ & $\mathrm{N}$ & NA \\
\hline SW & 08390020 & $\mathrm{~S} 10$ & Rio Hondo & $\begin{array}{l}\text { Partially } \\
\text { burned }\end{array}$ & 33.3713 & -105.2574 & 5,162 & $\begin{array}{l}04 / 03 / 2013,07 / 23 / 2013, \\
11 / 06 / 2013\end{array}$ & $\mathrm{Y}$ & $\mathrm{N}$ & NA \\
\hline \multicolumn{12}{|c|}{ Springs } \\
\hline$\overline{\mathrm{SP}}$ & 332905105473101 & SP1 & Rio Bonito & NA & 33.4848 & -105.7918 & 8,120 & $11 / 08 / 2013$ & $\mathrm{~N}$ & $\mathrm{Y}$ & NA \\
\hline SP & 332455105445701 & SP2 & Rio Ruidoso & NA & 33.4154 & -105.7492 & 8,072 & $11 / 07 / 2013$ & $\mathrm{~N}$ & $\mathrm{Y}$ & NA \\
\hline SP & 331937105350701 & SP3 & Rio Ruidoso & NA & 33.3269 & -105.5858 & 6,598 & $11 / 07 / 2013$ & $\mathrm{~N}$ & $\mathrm{Y}$ & NA \\
\hline SP & 332438105171201 & SP4 & Rio Bonito & NA & 33.4106 & -105.2867 & 5,337 & $11 / 07 / 2013$ & $\mathrm{~N}$ & $\mathrm{Y}$ & NA \\
\hline \multicolumn{12}{|c|}{ Groundwater } \\
\hline GW & 333149105302601 & W9 & Rio Bonito & NA & 33.5303 & -105.5072 & 6,181 & $05 / 08 / 2013$ & $\mathrm{Y}$ & $\mathrm{Y}$ & Permian regional aquifer system \\
\hline GW & 332247105383401 & W26 & Rio Ruidoso & NA & 33.3797 & -105.6428 & 7,143 & $06 / 26 / 2013$ & $\mathrm{Y}$ & $\mathrm{Y}$ & Permian regional aquifer system \\
\hline GW & 332355105270701 & W33 & Rio Ruidoso & NA & 33.3989 & -105.4525 & 5,912 & $11 / 07 / 2013$ & $\mathrm{~N}$ & $\mathrm{Y}^{1}$ & Permian regional aquifer system \\
\hline GW & 332437105170301 & W35 & Rio Bonito & NA & 33.4103 & -105.2842 & 5,372 & $05 / 09 / 2013$ & $\mathrm{Y}$ & $\mathrm{Y}$ & Permian regional aquifer system \\
\hline GW & 332355105472301 & W38 & Rio Ruidoso & NA & 33.3986 & -105.7897 & 9,816 & $06 / 25 / 2013$ & $\mathrm{Y}$ & $\mathrm{Y}$ & Tertiary volcanics \\
\hline GW & 332123105405201 & W39 & Rio Ruidoso & NA & 33.3564 & -105.6810 & 6,945 & $06 / 24 / 2013$ & $\mathrm{Y}$ & $\mathrm{Y}$ & Cretaceous shales and sandstones \\
\hline GW & 332635105401001 & W40 & Rio Bonito & NA & 33.4430 & -105.6693 & 7,017 & $05 / 07 / 2013$ & $\mathrm{Y}$ & $\mathrm{Y}$ & Tertiary volcanics \\
\hline GW & 332437105265601 & W41 & Rio Ruidoso & NA & 33.4102 & -105.4489 & 5,857 & $06 / 25 / 2013$ & $\mathrm{Y}$ & $\mathrm{Y}$ & Permian regional aquifer system \\
\hline GW & 332929105232501 & W42 & Rio Bonito & NA & 33.4915 & -105.3901 & 5,784 & $05 / 09 / 2013$ & $\mathrm{Y}$ & $\mathrm{Y}$ & Permian regional aquifer system \\
\hline
\end{tabular}

${ }^{1}$ Site 332355105270701 was sampled for stable isotopes only. 
Tritium values are reported in tritium units (TU), where $1 \mathrm{TU}$ is defined as one ${ }^{3} \mathrm{H}$ atom in $10^{18}$ atoms of hydrogen. Tritium values indicate whether or not a groundwater sample contains a fraction of young (post-1950s) recharge, with values less than $0.2 \mathrm{TU}$ representing groundwater that recharged prior to nuclear weapons testing, based on maximum prebomb initial activities of $7 \mathrm{TU}$ (Solomon and Cook, 2001) and a decay time of 61 years (1952-2013) using the equation:

$$
A=A_{0} e-\left(0.693 t / T_{1 / 2}\right)
$$

where

$$
\begin{array}{cl}
A & \text { is the final activity in } 2013 \text { (the year samples } \\
\text { were collected); } \\
A_{0} & \text { is the initial activity (the prebomb maximum } \\
\text { in 1952); } \\
t & \text { is the decay time, in years; and } \\
T_{1 / 2} & \text { is the half-life of tritium, } 12.26 \text { years. }
\end{array}
$$

Groundwater samples with ${ }^{3} \mathrm{H}$ values of $0.2 \mathrm{TU}$ or greater are likely to include some component of young (post-1950s) water but could also include a fraction of much older water as indicated by the concentrations of ${ }^{14} \mathrm{C}$.

All ${ }^{14} \mathrm{C}$ measurements are reported by the laboratory as absolute percent Modern (pM), which means that the laboratory results have been normalized for supposed carbon-13 $\left({ }^{13} \mathrm{C}\right)$ isotopic fractionation from an assumed initial value of -25 per mil to the measured $\delta^{13} \mathrm{C}$ of the sample. For groundwater age-dating analysis, normalized values do not accurately reflect most of the geochemical reactions that cause isotopic variation in $\delta^{13} \mathrm{C}$ of dissolved inorganic carbon (Plummer and others, 2012); therefore, for this study, ${ }^{14} \mathrm{C}$ results were converted to percent modern carbon (pmC) (nonnormalized) using the equations outlined in Plummer and others (2012). Nonnormalized ${ }^{14} \mathrm{C}$ values in pmC were used to calculate an unadjusted radiocarbon age in years before present relative to $1950\left(\mathrm{t}_{\text {unadj. }}\right)$ using the equation:

$$
t_{\text {unadj. }}=(5568 / \ln 2) * \ln \left(A_{0}{ }^{14} C_{m}\right)-((y-1950) / 1.029)
$$

where

$$
\begin{aligned}
& A_{0} \quad \text { is the initial }{ }^{14} \mathrm{C} \text { activity in } \mathrm{pmC} \text { at the time of } \\
& \text { recharge; } \\
& { }^{14} C_{m} \quad \text { is the measured concentration of }{ }^{14} \mathrm{C} \text {, in } \mathrm{pmC} \text {; } \\
& \text { and } \\
& y \quad \text { is the year of sample collection. }
\end{aligned}
$$

It was assumed that the initial $A_{0}$ is $100 \mathrm{pmC}$ because not enough data are available to determine the actual $A_{0}$ in the study area, which may be influenced by geochemical processes occurring during recharge. In addition, modeling of geochemical reactions in the aquifer and resulting mass transfers were not feasible because the sampled wells are not located along clearly defined flow paths as a result of variations in well depths, in local geology, and in proximity of the wells to potential recharge sources. Because most geochemical reactions that affect dissolved inorganic carbon lower the concentration of ${ }^{14} \mathrm{C}$ that would be measured in groundwater samples, not accounting for these reactions generally results in calculated ages being too old. Therefore, the assumption that $A_{0}$ is $100 \mathrm{pmC}$ along with the lack of correction for geochemical mass transfers means that the calculated unadjusted radiocarbon ages reported in this study should be interpreted as maximum values. Without geochemical modeling, the extent to which the unadjusted radiocarbon ages might overestimate actual groundwater ages cannot be accurately quantified.

Radioisotope samples were collected from seven groundwater wells in the upper Rio Hondo Basin between May and June 2013. Samples for ${ }^{3} \mathrm{H}$ were collected without filtering or preservation and were sent to the USGS Menlo Park Tritium Laboratory in Menlo, California, for analysis (Thatcher and others, 1977). Samples for ${ }^{14} \mathrm{C}$ were collected through a 0.45 -micrometer $(\mu \mathrm{m})$ filter and shipped to the Woods Hole Oceanographic Institution in Woods Hole, Massachusetts, for analysis (National Ocean Sciences Accelerator Mass Spectrometry Facility, 2010).

\section{Water Quality}

Water-quality samples were collected from 10 surfacewater sites and 8 groundwater wells (table 4). Unfiltered and filtered surface-water samples were collected in July 2012 and July 2013 after postfire monsoon rain events. Samples were collected during July 11-12, 2012, after 3.6 inches of precipitation were recorded on July 6-11, 2012, and during July 22-23, 2013, after 1.5 inches of precipitation were recorded on July 18-22, 2013, at the Sierra Blanca SNOTEL climate station (CL2) (Natural Resources Conservation Service, 2014). Unfiltered and filtered surface-water samples were also collected during periods of relatively stable hydrologic conditions (small change in streamflow prior to sampling and outside of monsoon season) in April and November 2013 (fig. 7; table 4). Samples were collected at sites located downstream from burned and unburned watersheds (fig. $6 B$ ). For the purposes of comparison, all sites located in the Rio Bonito watershed (S1, S2, S3, and S4) and on Eagle Creek (S9) were considered to be within burned watersheds. Three sites located on the Rio Ruidoso (S5, S6, and S7) were considered to be within an unburned watershed despite potentially receiving a small contribution of streamflow from the burned area. The remaining sites on the Rio Ruidoso (S8) and the Rio Hondo (S10) were considered partially burned and were not used for comparison (fig. $6 B$ ).

Standard USGS protocols were used to collect and process surface-water and groundwater samples (U.S. Geological Survey, 2006). Surface-water samples were collected using grab or equal-width increment methods, depending on streamflow conditions. Filtered groundwater samples were collected after purging at least three casing volumes (calculated from the height of water column and the well casing diameter) of water, or, if purging was not possible, 


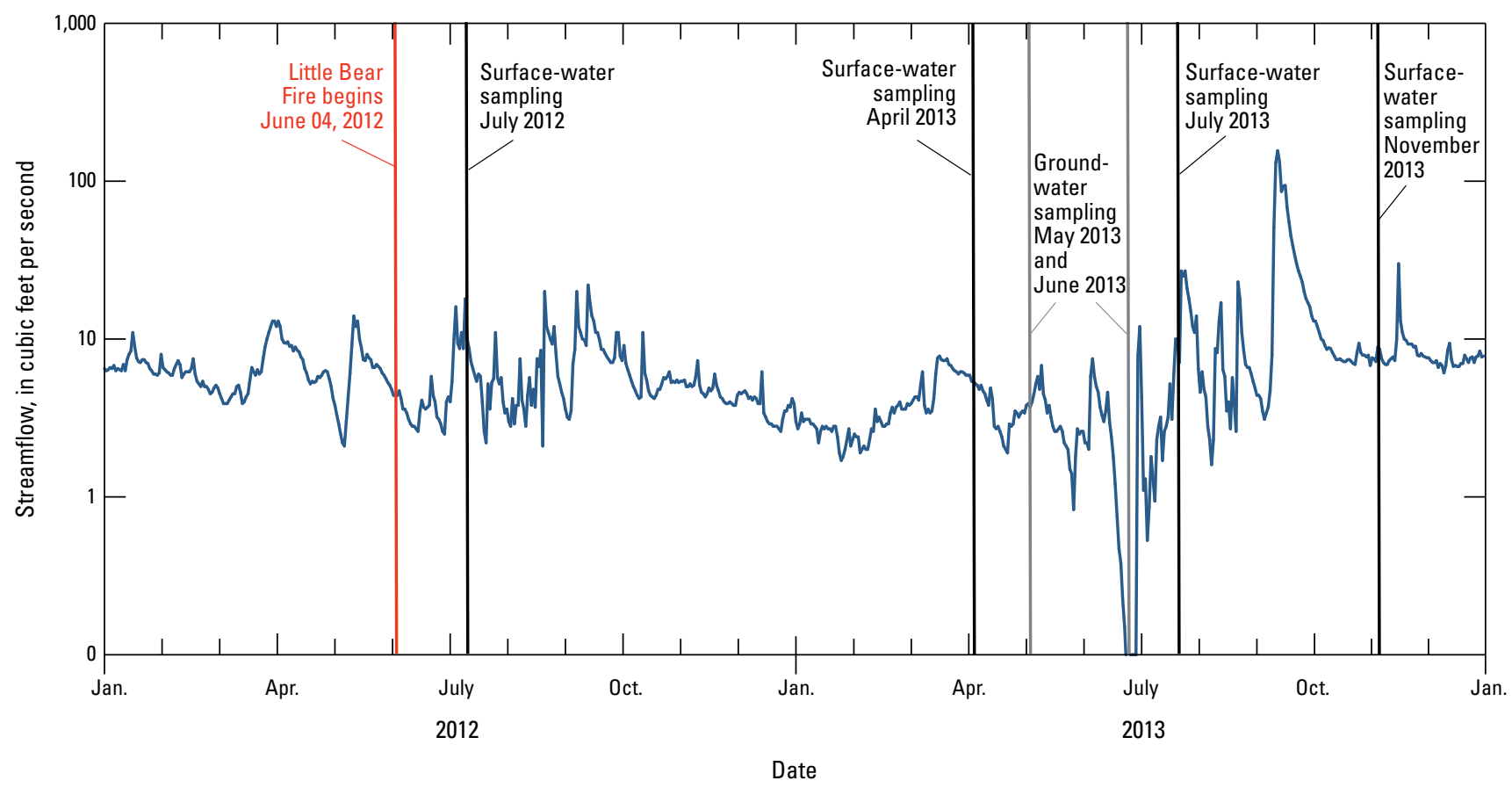

Figure 7. Daily mean streamflow for Rio Ruidoso at Hollywood, New Mexico (08387000; S6), January 1, 2012-December 31, 2013, and water-quality sampling dates, upper Rio Hondo Basin, Lincoln County, N. Mex.

it was ensured that the pressure tank had been completely emptied and that field measurements (water temperature, $\mathrm{pH}$, specific conductance, and dissolved oxygen [DO]) had stabilized prior to sampling (U.S. Geological Survey, 2006). Groundwater samples were collected before any pressure tanks and water-treatment systems for wells with installed pumps (wells W9, W35, W38, W39, W40, W41, and W42). Well W26 did not have an installed pump and was sampled using a submersible piston pump equipped with Teflon-lined tubing (U.S. Geological Survey, 2006).

Field measurements (temperature, $\mathrm{pH}$, specific conductance, and DO) were made onsite (or in the field), and major ions, trace elements, nutrients, alkalinity, and turbidity were analyzed in each water sample at the laboratory. Field measurements were made prior to sample collection and alkalinity values were measured in the field and in the laboratory by digital titration methods (Rounds, 2006).

Samples analyzed for dissolved major-ion, trace-element, and nutrient analyses were filtered through a $0.45-\mu \mathrm{m}$ filter that was preconditioned in the field with 2 liters (L) of deionized water and acidified to $\mathrm{pH}$ less than 2 (if necessary). Filtered and unfiltered samples were shipped to the USGS National Water Quality Laboratory (NWQL) in Lakewood, Colorado, for analysis (Fishman and Friedman, 1989; Fishman, 1993; Gabarino, 2006). The USGS NWQL reports concentrations as quantitative, estimated (semiquantitative), or censored (nonquantitative) (Childress and others, 1999). Quantitative results are reported with no accompanying remark and are equal to or greater than the laboratory reporting level (LRL). The LRL is defined as two times the long-term method detection level (LT-MDL). In general, when an analyte is not detected or is detected at a concentration less than the LT-MDL, the laboratory reports the analyte as less than (remark code of "<") the LRL, which limits the chance of a false negative result to no greater than 1 percent. Results for analytes that are detected at concentrations between the LT-MDL and the LRL are reported as estimated (remark code of "E").

\section{Quality-Control Samples}

In addition to environmental samples, quality-control samples (two field blanks and a replicate sample) were collected in the field during sampling to evaluate potential contamination and variability of results. A surface-water field blank was collected on April 4, 2013 (site S2), and a groundwater field blank was collected using the portable submersible sample pump on June 26, 2013 (well W26) (fig. $6 B$ ). Field blanks were prepared using NWQL certified inorganic blank water that was passed through the sampling equipment and filter, then processed and analyzed as a regular environmental sample. Constituents in the surface-water field blank did not exceed LRLs, except for unfiltered calcium and filtered fluoride, manganese, and dissolved organic carbon (DOC), which were measured at 0.022 milligrams per liter $(\mathrm{mg} / \mathrm{L}), 0.08 \mathrm{mg} / \mathrm{L}$ (estimated), 0.894 micrograms per liter $(\mu \mathrm{g} / \mathrm{L})$, and $79.5 \mathrm{mg} / \mathrm{L}$, respectively (table 5$)$. Dissolved organic carbon was collected by a separate filtration method 
Table 5. Results from field blanks and replicate water-quality samples collected in the upper Rio Hondo Basin, Lincoln County, New Mexico.

[E, estimated; --, not available; $\mu \mathrm{S} / \mathrm{cm}$ at $25^{\circ} \mathrm{C}$, microsiemens per centimeter at 25 degrees Celsius; $<$, less than; mg/L, milligrams per liter; CaCO ${ }_{3}$, calcium carbonate; $\mathrm{SiO}_{2}$, silicon dioxide; $\mathrm{N}$, nitrogen; $\mathrm{P}$, phosphorus; $\mu \mathrm{g} / \mathrm{L}$, micrograms per liter]

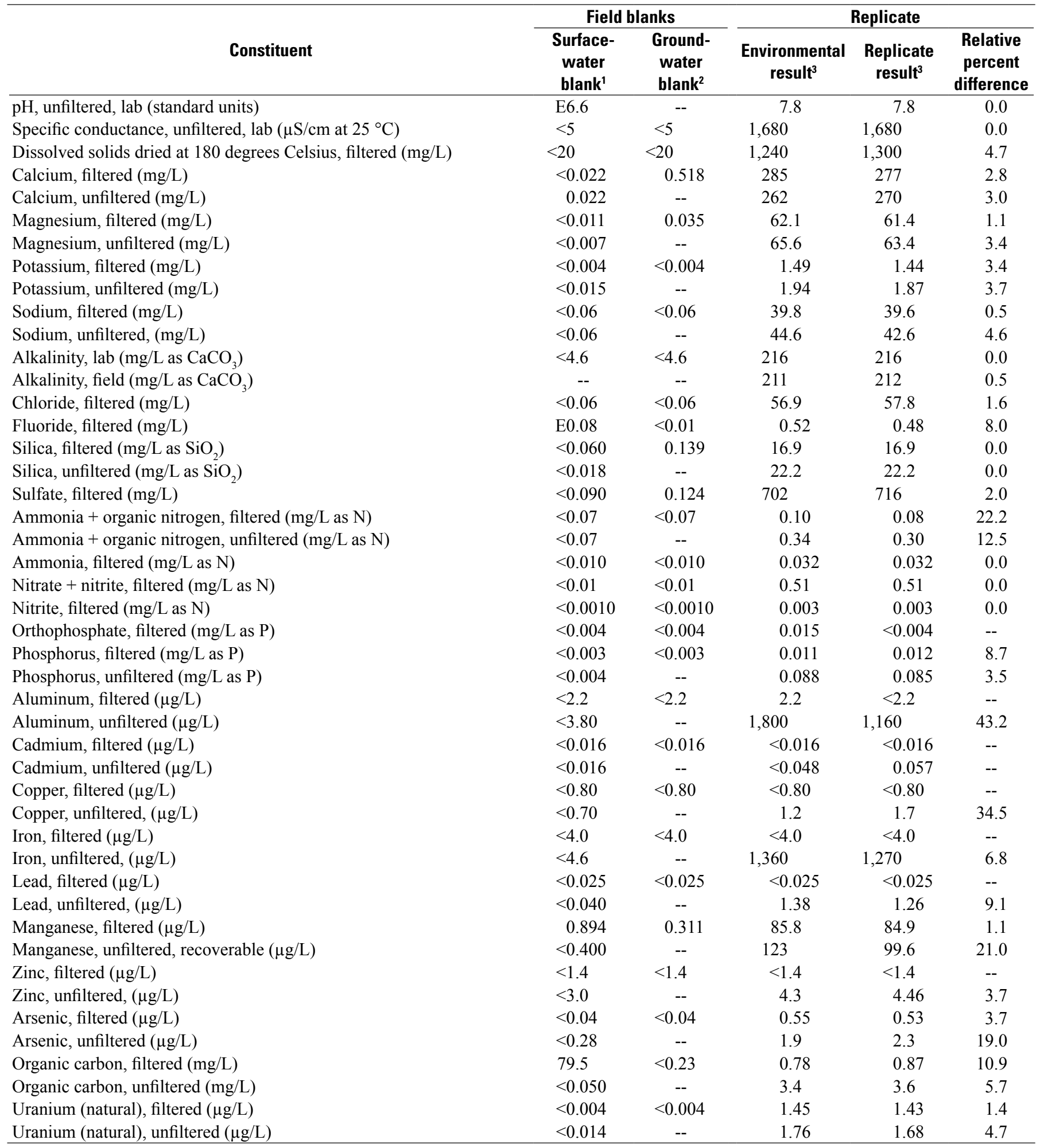

${ }^{1}$ Surface-water blank taken from site S2 (table 4) on April 4, 2013.

${ }^{2}$ Groundwater blank taken from well W26 (table 4) on June 26, 2013.

${ }^{3}$ Replicate taken from site S10 (table 4) on July 23, 2013. 
than the other dissolved constituents. It was determined that rinsing procedures for this filtration method were inadequate for DOC filtration, and contamination likely affected all environmental samples from April 2013, resulting in the rejection of these DOC results. Constituents in the groundwater field blank did not exceed LRLs, except for trace amounts $(<1.0 \mathrm{mg} / \mathrm{L})$ of filtered calcium, magnesium, silica, sulfate, and manganese (table 5). The concentrations of filtered calcium, magnesium, sulfate, and manganese in the field blank were less than the concentrations measured in the environmental sample collected at the same well, indicating that possible contamination likely did not affect the concentrations in the environmental sample. For example, although filtered calcium was measured in the groundwater field blank at $0.518 \mathrm{mg} / \mathrm{L}$, it was measured in the environmental sample to be $508 \mathrm{mg} / \mathrm{L}$ (table 6). Detections in the groundwater field blank could have resulted from the additional equipment used at W26 (submersible piston pump equipped with Teflon-lined tubing), which had been stored for a long period of time prior to sampling. The other groundwater wells did not require a pump for sampling, making it unlikely that any introduced contamination was present in other groundwater samples.

A sequential surface-water replicate sample was collected on July 23, 2013, at site S10 to evaluate variability in the stream, processing procedures, and analytical precision. A sequential surface-water replicate is a type of sample that is collected immediately after the environmental sample such that the samples are thought to be of the same composition. The relative percent difference (RPD) was used to determine differences in detected constituent concentrations for the replicate samples. The RPD was calculated as $\{(a-b) /[(a+b)$ $12]\} \times 100$, where $\mathrm{a}$ and $\mathrm{b}$ are concentrations in each replicate pair. Generally, the absolute value of the RPD between replicate samples was less than 10 percent, with a mean RPD of 7 percent. The calculated RPDs for some trace elements and nutrients ranged as much as 43.2 percent, with RPDs for selected trace elements exceeding 20 percent. The RPDs for trace elements that exceeded 20 percent were observed for unfiltered manganese (21.0 percent), copper (34.5 percent), and aluminum (43.2 percent) and filtered ammonia + organic nitrogen (22.2 percent). The RPDs for constituents that exceeded 10 percent, but were less than 20 percent, were observed for unfiltered ammonia + organic nitrogen (12.5 percent) and arsenic (19.0 percent) and filtered organic carbon (10.9 percent) (table 5). These larger RPDs may have been due to variability in stream concentrations over time, sample processing, analytical precision, or low constituent concentrations (near the reporting level). Instantaneous streamflow-gage height data at the sampling site (S10) show that stage was stable between the time of collection of the environmental and replicate samples. General agreement (mostly less than 10 percent RPD) between these samples indicates that the environmental sample was representative of the river under stable conditions.

Water-quality results also revealed some uncertainty with laboratory reporting for selected parameters. For most groundwater samples, orthophosphate concentrations were greater than phosphorus concentrations. This may be due to the methods or reporting levels used by the laboratory for these constituents. In addition, results for some constituents showed greater concentrations in filtered samples when compared to unfiltered samples. These differences were generally small and within allowable laboratory error (10 percent) (table 6). 
Table 6. Water-quality data for surface-water and groundwater sites sampled in the upper Rio Hondo Basin, Lincoln County, New Mexico.

$\left[\mathrm{mm}\right.$, month; dd, day; yyyy, year; $\mathrm{ft} / \mathrm{s}$, cubic feet per second; $\mathrm{mg} / \mathrm{L}$, milligrams per liter; --, no data; NA, not applicable; $\mu \mathrm{S} / \mathrm{cm}$ at $25^{\circ} \mathrm{C}$, microsiemens per centimeter at 25 degrees Celsius; ${ }^{\circ} \mathrm{C}$, degrees Celsius; NTRU, nephelometric turbidity ratio unit; $<$, less than; E, estimated; $\mathrm{CaCO}_{3}$, calcium carbonate; $\mathrm{SiO}_{2}$, silicon dioxide; +, plus; $\mathrm{N}$, nitrogen; $\mathrm{P}$, phosphorus; $\mu \mathrm{g} / \mathrm{L}$, micrograms per liter]

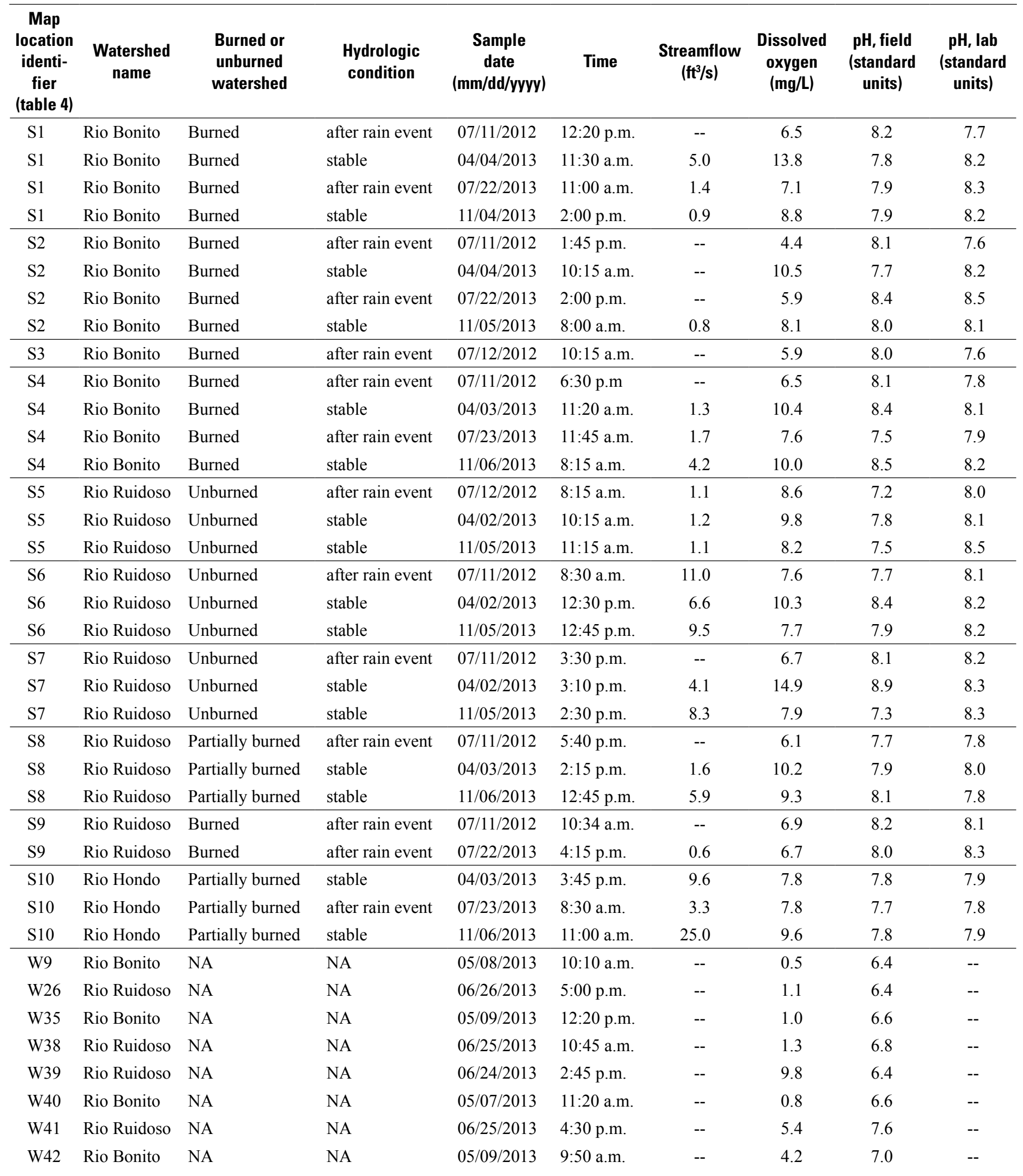




\section{Water Resources During Drought Conditions and Postfire Water Quality in the Upper Rio Hondo Basin, Lincoln County}

Table 6. Water-quality data for surface-water and groundwater sites sampled in the upper Rio Hondo Basin, Lincoln County, New Mexico.-Continued

[mm, month; dd, day; yyyy, year; $\mathrm{ft}^{3} / \mathrm{s}$, cubic feet per second; mg/L, milligrams per liter; --, no data; NA, not applicable; $\mu \mathrm{S} / \mathrm{cm}$ at $25^{\circ} \mathrm{C}$, microsiemens per centimeter at 25 degrees Celsius; ${ }^{\circ} \mathrm{C}$, degrees Celsius; $\mathrm{NTRU}$, nephelometric turbidity ratio unit; <, less than; $\mathrm{E}$, estimated; $\mathrm{CaCO}_{3}, \mathrm{calcium}$ carbonate; $\mathrm{SiO}_{2}$, silicon dioxide; +, plus; $\mathrm{N}$, nitrogen; $\mathrm{P}$, phosphorus; $\mu \mathrm{g} / \mathrm{L}$, micrograms per liter]

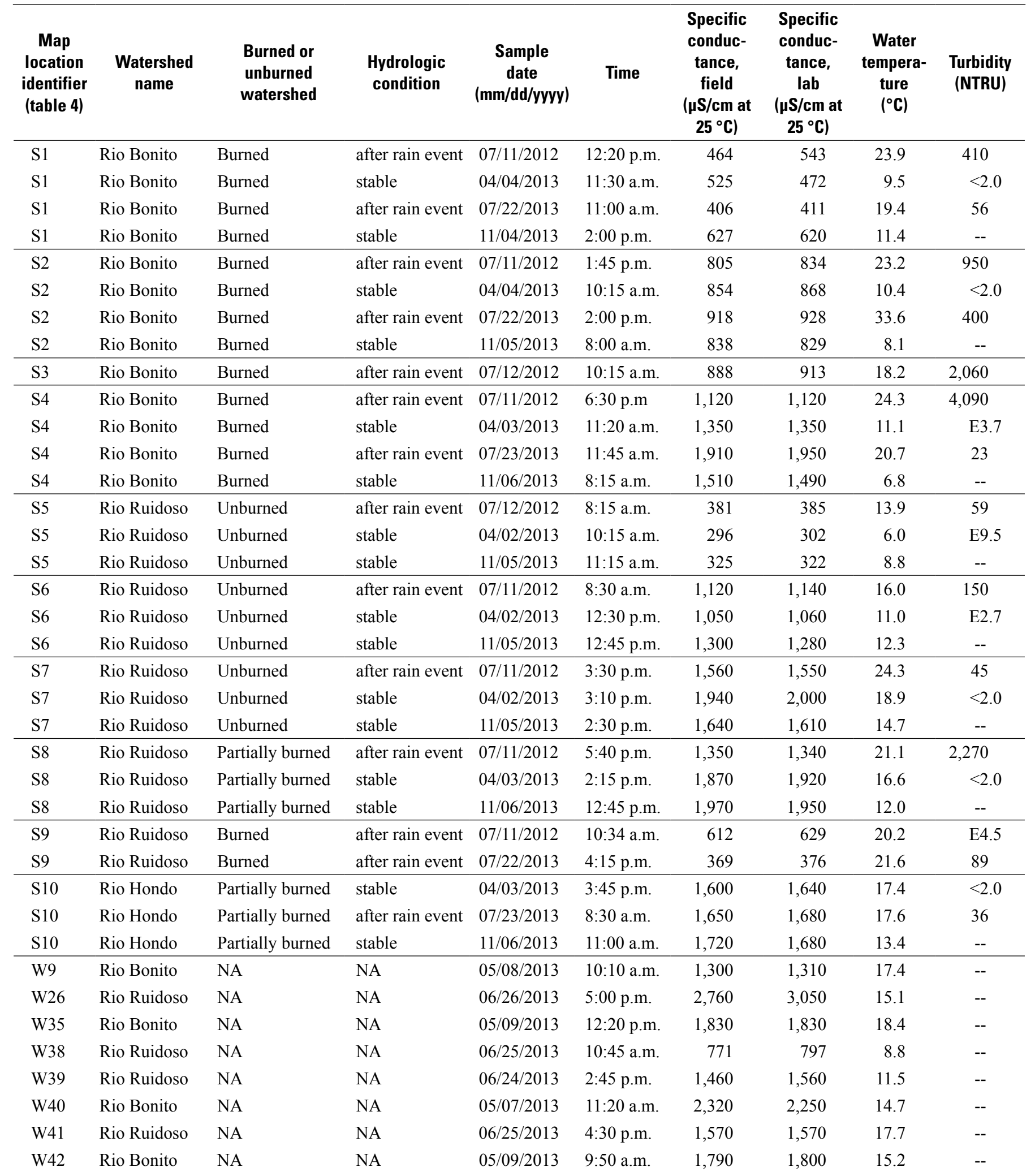


Table 6. Water-quality data for surface-water and groundwater sites sampled in the upper Rio Hondo Basin, Lincoln County, New Mexico.-Continued

[mm, month; dd, day; yyyy, year; $\mathrm{ft}^{3} / \mathrm{s}$, cubic feet per second; $\mathrm{mg} / \mathrm{L}$, milligrams per liter; --, no data; NA, not applicable; $\mu \mathrm{S} / \mathrm{cm}$ at $25^{\circ} \mathrm{C}$, microsiemens per centimeter at 25 degrees Celsius; ${ }^{\circ} \mathrm{C}$, degrees Celsius; $\mathrm{NTRU}$, nephelometric turbidity ratio unit; $<$, less than; $\mathrm{E}$, estimated; $\mathrm{CaCO}{ }_{3}$, calcium carbonate; $\mathrm{SiO}$, silicon dioxide; +, plus; $\mathrm{N}$, nitrogen; $\mathrm{P}$, phosphorus; $\mu \mathrm{g} / \mathrm{L}$, micrograms per liter]

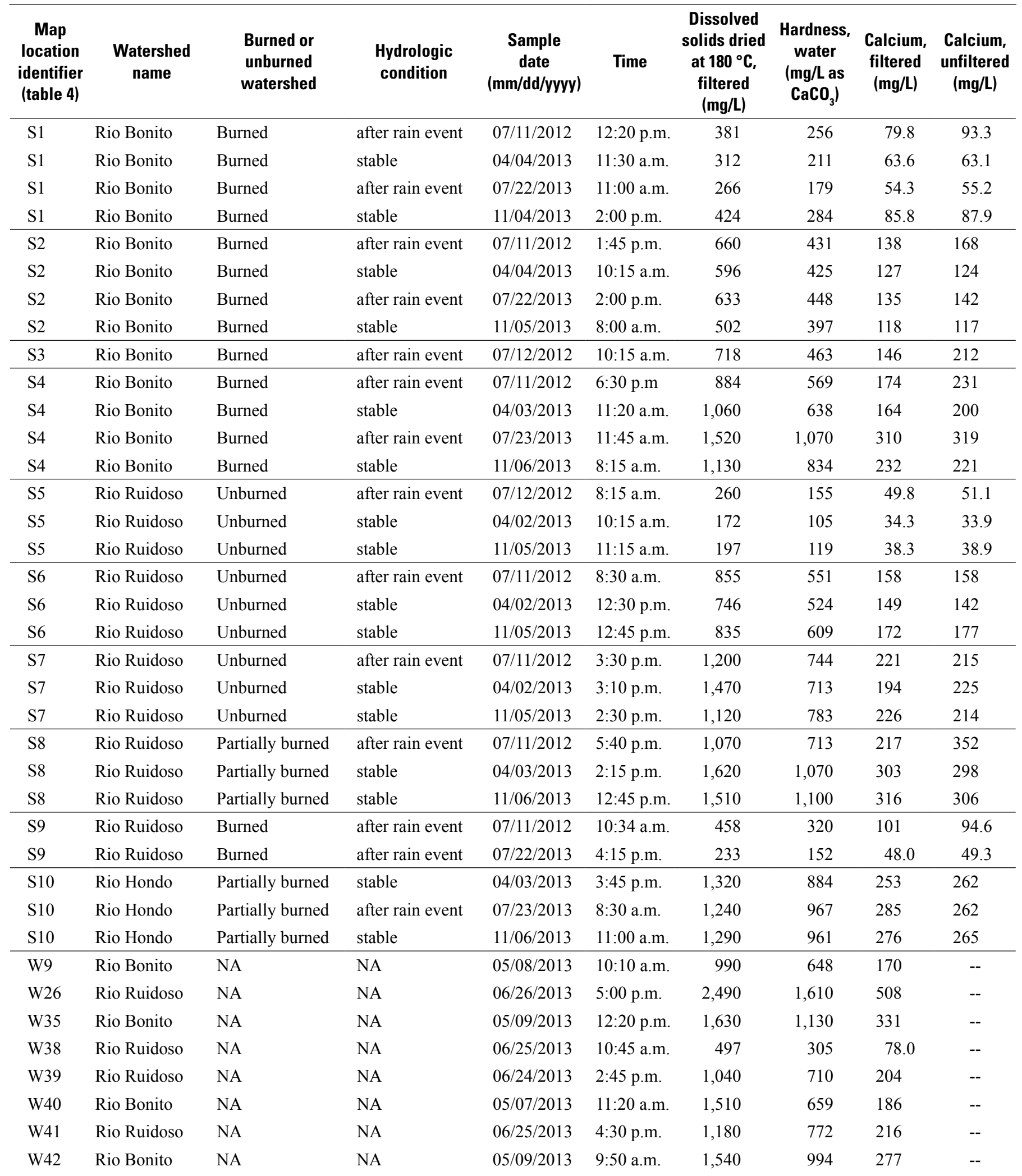




\section{Water Resources During Drought Conditions and Postfire Water Quality in the Upper Rio Hondo Basin, Lincoln County}

Table 6. Water-quality data for surface-water and groundwater sites sampled in the upper Rio Hondo Basin, Lincoln County, New Mexico.-Continued

[mm, month; dd, day; yyyy, year; $\mathrm{ft}^{3} / \mathrm{s}$, cubic feet per second; mg/L, milligrams per liter; --, no data; NA, not applicable; $\mu \mathrm{S} / \mathrm{cm}$ at $25^{\circ} \mathrm{C}$, microsiemens per centimeter at 25 degrees Celsius; ${ }^{\circ} \mathrm{C}$, degrees Celsius; $\mathrm{NTRU}$, nephelometric turbidity ratio unit; <, less than; $\mathrm{E}$, estimated; $\mathrm{CaCO}_{3}$, calcium carbonate; $\mathrm{SiO}_{2}$, silicon dioxide; +, plus; $\mathrm{N}$, nitrogen; $\mathrm{P}$, phosphorus; $\mu \mathrm{g} / \mathrm{L}$, micrograms per liter]

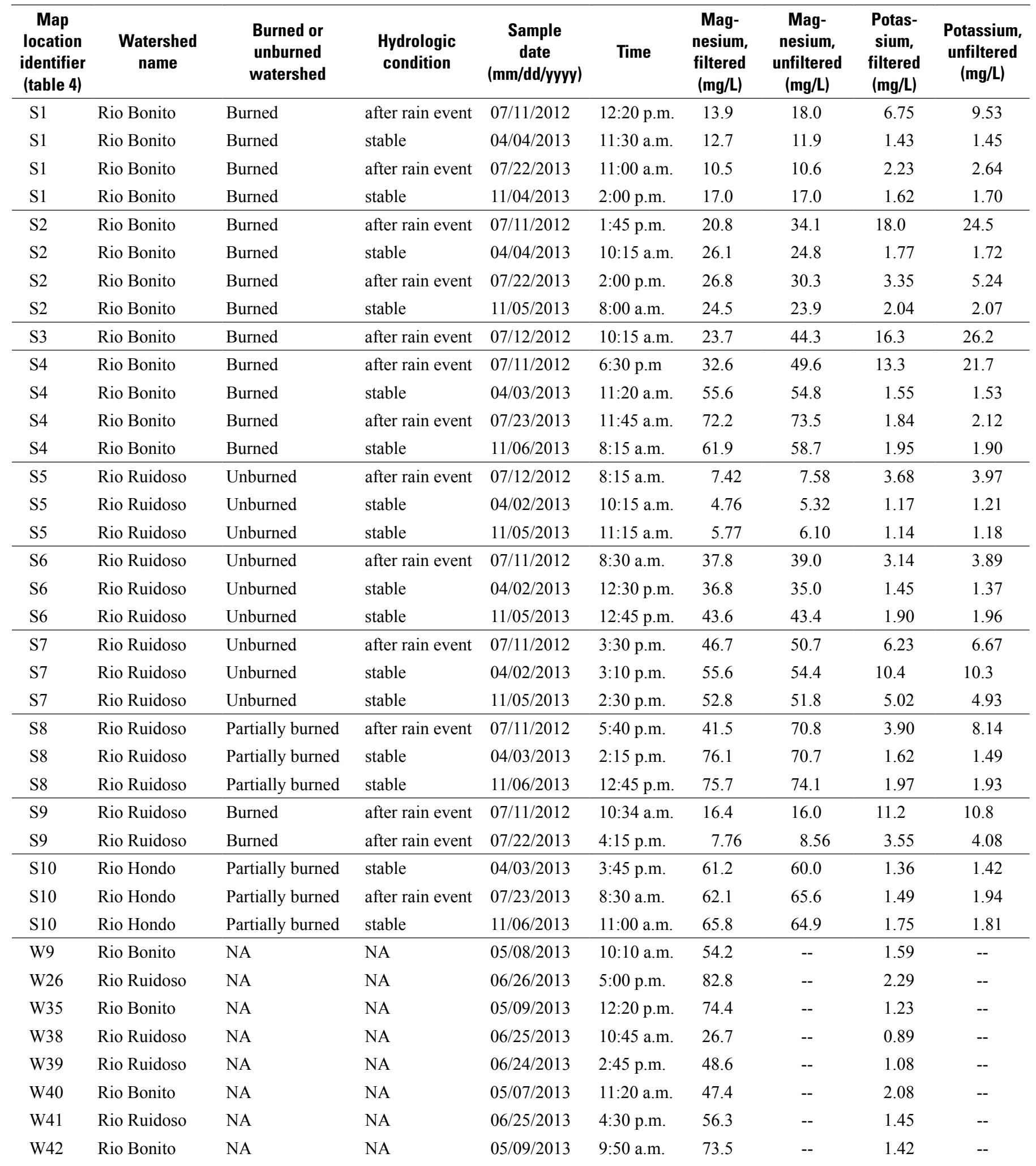


Table 6. Water-quality data for surface-water and groundwater sites sampled in the upper Rio Hondo Basin, Lincoln County, New Mexico.-Continued

[mm, month; dd, day; yyyy, year; $\mathrm{ft}^{3} / \mathrm{s}$, cubic feet per second; $\mathrm{mg} / \mathrm{L}$, milligrams per liter; --, no data; NA, not applicable; $\mu \mathrm{S} / \mathrm{cm}$ at $25^{\circ} \mathrm{C}$, microsiemens per centimeter at 25 degrees Celsius; ${ }^{\circ} \mathrm{C}$, degrees Celsius; $\mathrm{NTRU}$, nephelometric turbidity ratio unit; $<$, less than; $\mathrm{E}$, estimated; $\mathrm{CaCO}{ }_{3}$, calcium carbonate; $\mathrm{SiO}$, silicon dioxide; +, plus; $\mathrm{N}$, nitrogen; $\mathrm{P}$, phosphorus; $\mu \mathrm{g} / \mathrm{L}$, micrograms per liter]

\begin{tabular}{|c|c|c|c|c|c|c|c|c|}
\hline $\begin{array}{c}\text { Map } \\
\text { location } \\
\text { identifier } \\
\text { (table 4) }\end{array}$ & $\begin{array}{l}\text { Watershed } \\
\text { name }\end{array}$ & $\begin{array}{c}\text { Burned or } \\
\text { unburned } \\
\text { watershed }\end{array}$ & $\begin{array}{l}\text { Hydrologic } \\
\text { condition }\end{array}$ & $\begin{array}{c}\text { Sample } \\
\text { date } \\
\text { (mm/dd/yyyy) }\end{array}$ & Time & $\begin{array}{c}\text { Sodium } \\
\text { adsorption } \\
\text { ratio } \\
\text { (number) }\end{array}$ & $\begin{array}{c}\text { Sodium, } \\
\text { filtered } \\
\text { (mg/L) }\end{array}$ & $\begin{array}{c}\text { Sodium, } \\
\text { unfiltered, } \\
\text { (mg/L) }\end{array}$ \\
\hline $\mathrm{S} 1$ & Rio Bonito & Burned & after rain event & $07 / 11 / 2012$ & 12:20 p.m. & 0.36 & 13.3 & 13.5 \\
\hline $\mathrm{S} 1$ & Rio Bonito & Burned & stable & $04 / 04 / 2013$ & 11:30 a.m. & 0.37 & 12.4 & 12.4 \\
\hline $\mathrm{S} 1$ & Rio Bonito & Burned & after rain event & $07 / 22 / 2013$ & 11:00 a.m. & 0.38 & 11.6 & 11.1 \\
\hline $\mathrm{S} 2$ & Rio Bonito & Burned & after rain event & $07 / 11 / 2012$ & 1:45 p.m. & 0.34 & 16.3 & 16.6 \\
\hline $\mathrm{S} 2$ & Rio Bonito & Burned & stable & $04 / 04 / 2013$ & 10:15 a.m. & 0.57 & 27.2 & 28.1 \\
\hline $\mathrm{S} 2$ & Rio Bonito & Burned & after rain event & $07 / 22 / 2013$ & 2:00 p.m. & 0.68 & 33.3 & 32.0 \\
\hline $\mathrm{S} 2$ & Rio Bonito & Burned & stable & $11 / 05 / 2013$ & 8:00 a.m. & 0.64 & 29.3 & 28.4 \\
\hline S4 & Rio Bonito & Burned & after rain event & $07 / 23 / 2013$ & 11:45 a.m. & 0.73 & 55.0 & 57.5 \\
\hline S4 & Rio Bonito & Burned & stable & $11 / 06 / 2013$ & 8:15 a.m. & 0.72 & 47.9 & 45.4 \\
\hline S5 & Rio Ruidoso & Unburned & after rain event & $07 / 12 / 2012$ & 8:15 a.m. & 0.63 & 18.0 & 17.4 \\
\hline S5 & Rio Ruidoso & Unburned & stable & $04 / 02 / 2013$ & 10:15 a.m. & 0.65 & 15.2 & 15.6 \\
\hline S5 & Rio Ruidoso & Unburned & stable & $11 / 05 / 2013$ & 11:15 a.m. & 0.61 & 15.3 & 15.4 \\
\hline S6 & Rio Ruidoso & Unburned & after rain event & $07 / 11 / 2012$ & 8:30 a.m. & 0.82 & 44.1 & 44.0 \\
\hline S6 & Rio Ruidoso & Unburned & stable & $04 / 02 / 2013$ & 12:30 p.m. & 0.78 & 40.9 & 42.0 \\
\hline S6 & Rio Ruidoso & Unburned & stable & $11 / 05 / 2013$ & 12:45 p.m. & 0.96 & 54.4 & 54.8 \\
\hline S7 & Rio Ruidoso & Unburned & after rain event & $07 / 11 / 2012$ & 3:30 p.m. & 1.21 & 75.7 & 78.2 \\
\hline S9 & Rio Ruidoso & Burned & after rain event & $07 / 22 / 2013$ & 4:15 p.m. & 0.45 & 12.9 & 12.6 \\
\hline $\mathrm{S} 10$ & Rio Hondo & Partially burned & stable & $04 / 03 / 2013$ & 3:45 p.m. & 0.61 & 41.7 & 41.8 \\
\hline $\mathrm{S} 10$ & Rio Hondo & Partially burned & after rain event & $07 / 23 / 2013$ & 8:30 a.m. & 0.56 & 39.8 & 44.6 \\
\hline $\mathrm{S} 10$ & Rio Hondo & Partially burned & stable & $11 / 06 / 2013$ & 11:00 a.m. & 0.72 & 51.4 & 49.8 \\
\hline W9 & Rio Bonito & NA & NA & $05 / 08 / 2013$ & 10:10 a.m. & 0.84 & 48.9 & -- \\
\hline W26 & Rio Ruidoso & NA & NA & $06 / 26 / 2013$ & 5:00 p.m. & 0.87 & 80.5 & -- \\
\hline W35 & Rio Bonito & NA & NA & $05 / 09 / 2013$ & 12:20 p.m. & 0.38 & 29.5 & -- \\
\hline W38 & Rio Ruidoso & NA & NA & $06 / 25 / 2013$ & 10:45 a.m. & 0.77 & 31.0 & -- \\
\hline W39 & Rio Ruidoso & NA & NA & $06 / 24 / 2013$ & 2:45 p.m. & 1.07 & 65.5 & -- \\
\hline W40 & Rio Bonito & NA & NA & $05 / 07 / 2013$ & 11:20 a.m. & 4.12 & 243 & -- \\
\hline W41 & Rio Ruidoso & NA & NA & $06 / 25 / 2013$ & 4:30 p.m. & 0.9 & 57.6 & -- \\
\hline W42 & Rio Bonito & NA & NA & $05 / 09 / 2013$ & 9:50 a.m. & 0.76 & 54.9 & -- \\
\hline
\end{tabular}




\section{Water Resources During Drought Conditions and Postfire Water Quality in the Upper Rio Hondo Basin, Lincoln County}

Table 6. Water-quality data for surface-water and groundwater sites sampled in the upper Rio Hondo Basin, Lincoln County, New Mexico.-Continued

[mm, month; dd, day; yyyy, year; $\mathrm{ft}^{3} / \mathrm{s}$, cubic feet per second; mg/L, milligrams per liter; --, no data; NA, not applicable; $\mu \mathrm{S} / \mathrm{cm}$ at $25^{\circ} \mathrm{C}$, microsiemens per centimeter at 25 degrees Celsius; ${ }^{\circ} \mathrm{C}$, degrees Celsius; $\mathrm{NTRU}$, nephelometric turbidity ratio unit; <, less than; $\mathrm{E}$, estimated; $\mathrm{CaCO}_{3}, \mathrm{calcium}$ carbonate; $\mathrm{SiO}_{2}$, silicon dioxide; +, plus; $\mathrm{N}$, nitrogen; $\mathrm{P}$, phosphorus; $\mu \mathrm{g} / \mathrm{L}$, micrograms per liter]

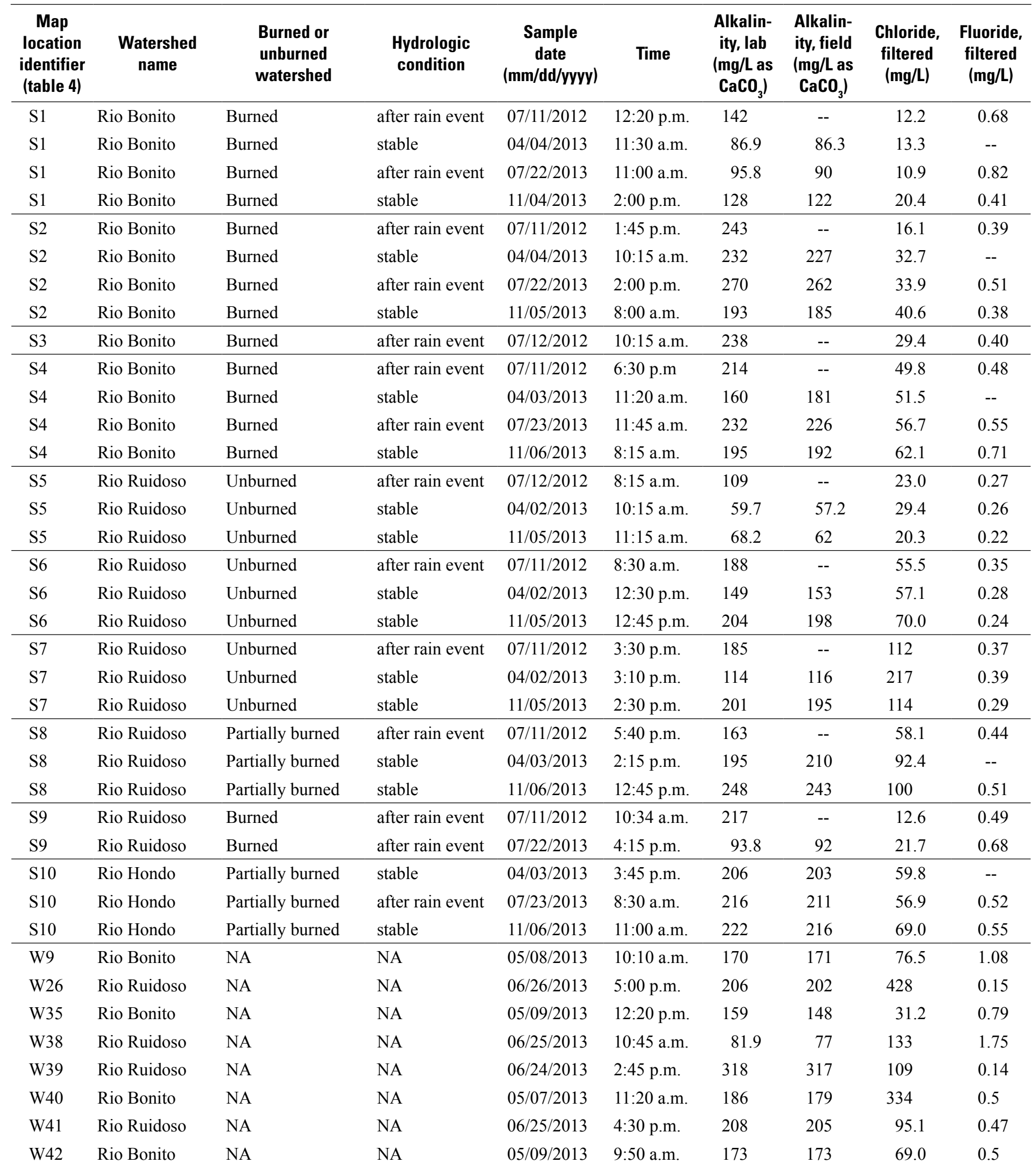


Table 6. Water-quality data for surface-water and groundwater sites sampled in the upper Rio Hondo Basin, Lincoln County, New Mexico.-Continued

[mm, month; dd, day; yyyy, year; $\mathrm{ft}^{3} / \mathrm{s}$, cubic feet per second; $\mathrm{mg} / \mathrm{L}$, milligrams per liter; --, no data; NA, not applicable; $\mu \mathrm{S} / \mathrm{cm}$ at $25^{\circ} \mathrm{C}$, microsiemens per centimeter at 25 degrees Celsius; ${ }^{\circ} \mathrm{C}$, degrees Celsius; $\mathrm{NTRU}$, nephelometric turbidity ratio unit; $<$, less than; $\mathrm{E}$, estimated; $\mathrm{CaCO}{ }_{3}$, calcium carbonate; $\mathrm{SiO}$, silicon dioxide; +, plus; $\mathrm{N}$, nitrogen; $\mathrm{P}$, phosphorus; $\mu \mathrm{g} / \mathrm{L}$, micrograms per liter]

\begin{tabular}{|c|c|c|c|c|c|c|c|c|c|}
\hline $\begin{array}{c}\text { Map } \\
\text { location } \\
\text { identifier } \\
\text { (table 4) }\end{array}$ & $\begin{array}{l}\text { Watershed } \\
\text { name }\end{array}$ & $\begin{array}{l}\text { Burned or } \\
\text { unburned } \\
\text { watershed }\end{array}$ & $\begin{array}{l}\text { Hydrologic } \\
\text { condition }\end{array}$ & $\begin{array}{c}\text { Sample } \\
\text { date } \\
\text { (mm/dd/yyyy) }\end{array}$ & Time & $\begin{array}{c}\text { Silica, } \\
\text { filtered } \\
\text { (mg/L as } \\
\left.\mathrm{SiO}_{2}\right)\end{array}$ & $\begin{array}{c}\text { Silica, } \\
\text { unfiltered } \\
\text { (mg/L as } \\
\left.\mathrm{SiO}_{2}\right)\end{array}$ & $\begin{array}{c}\text { Sulfate, } \\
\text { filtered } \\
\text { (mg/L) }\end{array}$ & $\begin{array}{c}\text { Ammonia } \\
+ \text { organic } \\
\text { nitrogen, } \\
\text { filtered } \\
\text { (mg/L as } \mathrm{N} \text { ) }\end{array}$ \\
\hline $\mathrm{S} 1$ & Rio Bonito & Burned & after rain event & $07 / 11 / 2012$ & 12:20 p.m. & 13.4 & 52.0 & 120 & 1.8 \\
\hline $\mathrm{S} 1$ & Rio Bonito & Burned & stable & $04 / 04 / 2013$ & 11:30 a.m. & 13.5 & 12.0 & 127 & 0.13 \\
\hline $\mathrm{S} 2$ & Rio Bonito & Burned & after rain event & $07 / 11 / 2012$ & 1:45 p.m. & 9.91 & 83.9 & 182 & 4.5 \\
\hline $\mathrm{S} 2$ & Rio Bonito & Burned & stable & $04 / 04 / 2013$ & 10:15 a.m. & 14.4 & 12.6 & 206 & 0.15 \\
\hline $\mathrm{S} 2$ & Rio Bonito & Burned & after rain event & $07 / 22 / 2013$ & 2:00 p.m. & 19.0 & 51.0 & 207 & 0.47 \\
\hline $\mathrm{S} 2$ & Rio Bonito & Burned & stable & $11 / 05 / 2013$ & 8:00 a.m. & 10.6 & 9.46 & 213 & 0.25 \\
\hline $\mathrm{S} 4$ & Rio Bonito & Burned & after rain event & $07 / 23 / 2013$ & $11: 45$ a.m. & 17.5 & 21.8 & 701 & 0.13 \\
\hline S4 & Rio Bonito & Burned & stable & $11 / 06 / 2013$ & 8:15 a.m. & 15.3 & 13.9 & 588 & 0.1 \\
\hline S5 & Rio Ruidoso & Unburned & after rain event & $07 / 12 / 2012$ & 8:15 a.m. & 11.2 & 17.1 & 49.1 & 0.82 \\
\hline S5 & Rio Ruidoso & Unburned & stable & $04 / 02 / 2013$ & 10:15 a.m. & 8.86 & 9.18 & 38.0 & 0.11 \\
\hline S5 & Rio Ruidoso & Unburned & stable & $11 / 05 / 2013$ & 11:15 a.m. & 9.56 & 8.78 & 56.3 & 0.12 \\
\hline S6 & Rio Ruidoso & Unburned & after rain event & $07 / 11 / 2012$ & 8:30 a.m. & 12.7 & 23.6 & 350 & 0.48 \\
\hline S6 & Rio Ruidoso & Unburned & stable & $04 / 02 / 2013$ & 12:30 p.m. & 8.46 & 7.61 & 347 & 0.14 \\
\hline S6 & Rio Ruidoso & Unburned & stable & $11 / 05 / 2013$ & 12:45 p.m. & 12.4 & 11.0 & 429 & 0.14 \\
\hline S7 & Rio Ruidoso & Unburned & after rain event & $07 / 11 / 2012$ & 3:30 p.m. & 14.1 & 18.6 & 534 & 0.34 \\
\hline S9 & Rio Ruidoso & Burned & after rain event & $07 / 11 / 2012$ & 10:34 a.m. & 12.1 & 11.6 & 105 & 3.1 \\
\hline S9 & Rio Ruidoso & Burned & after rain event & $07 / 22 / 2013$ & 4:15 p.m. & 13.7 & 24.1 & 53.7 & 0.33 \\
\hline $\mathrm{S} 10$ & Rio Hondo & Partially burned & stable & $04 / 03 / 2013$ & 3:45 p.m. & 16.0 & 13.8 & 719 & 0.09 \\
\hline $\mathrm{S} 10$ & Rio Hondo & Partially burned & after rain event & $07 / 23 / 2013$ & 8:30 a.m. & 16.9 & 22.2 & 702 & 0.1 \\
\hline $\mathrm{S} 10$ & Rio Hondo & Partially burned & stable & $11 / 06 / 2013$ & 11:00 a.m. & 16.1 & 14.7 & 702 & 0.1 \\
\hline W9 & Rio Bonito & NA & NA & $05 / 08 / 2013$ & 10:10 a.m. & 19.3 & -- & 475 & $<0.07$ \\
\hline W26 & Rio Ruidoso & NA & NA & $06 / 26 / 2013$ & 5:00 p.m. & 21.5 & -- & 1,000 & $<0.07$ \\
\hline W35 & Rio Bonito & NA & NA & $05 / 09 / 2013$ & 12:20 p.m. & 18.8 & -- & 973 & $<0.07$ \\
\hline W38 & Rio Ruidoso & NA & NA & $06 / 25 / 2013$ & 10:45 a.m. & 16.4 & -- & 114 & $<0.07$ \\
\hline W39 & Rio Ruidoso & NA & NA & $06 / 24 / 2013$ & $2: 45$ p.m. & 18.6 & -- & 424 & $<0.07$ \\
\hline W40 & Rio Bonito & NA & NA & $05 / 07 / 2013$ & 11:20 a.m. & 15.9 & -- & 534 & 0.12 \\
\hline W41 & Rio Ruidoso & NA & NA & $06 / 25 / 2013$ & 4:30 p.m. & 15.8 & -- & 564 & $<0.07$ \\
\hline W42 & Rio Bonito & NA & NA & $05 / 09 / 2013$ & 9:50 a.m. & 18.2 & -- & 821 & $<0.07$ \\
\hline
\end{tabular}


Table 6. Water-quality data for surface-water and groundwater sites sampled in the upper Rio Hondo Basin, Lincoln County, New Mexico.-Continued

[mm, month; dd, day; yyyy, year; $\mathrm{ft}^{3} / \mathrm{s}$, cubic feet per second; mg/L, milligrams per liter; --, no data; NA, not applicable; $\mu \mathrm{S} / \mathrm{cm}$ at $25{ }^{\circ} \mathrm{C}$, microsiemens per centimeter at 25 degrees Celsius; ${ }^{\circ} \mathrm{C}$, degrees Celsius; $\mathrm{NTRU}$, nephelometric turbidity ratio unit; $<$, less than; $\mathrm{E}$, estimated; $\mathrm{CaCO}$, calcium carbonate; $\mathrm{SiO}_{2}$, silicon dioxide; + , plus; $\mathrm{N}$, nitrogen; $\mathrm{P}$, phosphorus; $\mu \mathrm{g} / \mathrm{L}$, micrograms per liter]

\begin{tabular}{|c|c|c|c|c|c|c|c|c|c|}
\hline $\begin{array}{l}\text { Map } \\
\text { location } \\
\text { identifier } \\
\text { (table 4) }\end{array}$ & $\begin{array}{l}\text { Watershed } \\
\text { name }\end{array}$ & $\begin{array}{l}\text { Burned or } \\
\text { unburned } \\
\text { watershed }\end{array}$ & $\begin{array}{l}\text { Hydrologic } \\
\text { condition }\end{array}$ & $\begin{array}{c}\text { Sample } \\
\text { date } \\
\text { (mm/dd/yyyy) }\end{array}$ & Time & $\begin{array}{c}\text { Ammonia } \\
\text { + organic } \\
\text { nitrogen, } \\
\text { unfiltered } \\
\text { (mg/L as } \mathrm{N} \text { ) }\end{array}$ & $\begin{array}{c}\text { Ammonia, } \\
\text { filtered } \\
\text { (mg/L as } N \text { ) }\end{array}$ & $\begin{array}{c}\text { Nitrate } \\
+ \text { nitrite, } \\
\text { filtered } \\
\text { (mg/L as } \mathrm{N})\end{array}$ & $\begin{array}{c}\text { Nitrite, } \\
\text { filtered } \\
\text { (mg/L as } \mathrm{N})\end{array}$ \\
\hline $\mathrm{S} 1$ & Rio Bonito & Burned & after rain event & $07 / 11 / 2012$ & 12:20 p.m. & 6.4 & 0.289 & 0.76 & 0.033 \\
\hline $\mathrm{S} 1$ & Rio Bonito & Burned & stable & $04 / 04 / 2013$ & 11:30 a.m. & 0.15 & $<0.010$ & 2.53 & 0.003 \\
\hline $\mathrm{S} 1$ & Rio Bonito & Burned & after rain event & $07 / 22 / 2013$ & 11:00 a.m. & 0.81 & 0.023 & 2.28 & 0.009 \\
\hline $\mathrm{S} 1$ & Rio Bonito & Burned & stable & $11 / 04 / 2013$ & 2:00 p.m. & 0.15 & $<0.010$ & 3.41 & 0.004 \\
\hline $\mathrm{S} 2$ & Rio Bonito & Burned & after rain event & $07 / 11 / 2012$ & 1:45 p.m. & 18 & 0.034 & $<0.01$ & $<0.001$ \\
\hline $\mathrm{S} 2$ & Rio Bonito & Burned & stable & $04 / 04 / 2013$ & 10:15 a.m. & 0.16 & $<0.010$ & $<0.01$ & $<0.001$ \\
\hline $\mathrm{S} 2$ & Rio Bonito & Burned & after rain event & $07 / 22 / 2013$ & 2:00 p.m. & 2.4 & 0.067 & 0.06 & 0.013 \\
\hline $\mathrm{S} 2$ & Rio Bonito & Burned & stable & $11 / 05 / 2013$ & 8:00 a.m. & 0.30 & $<0.010$ & 0.27 & 0.005 \\
\hline S3 & Rio Bonito & Burned & after rain event & $07 / 12 / 2012$ & 10:15 a.m. & 27 & 0.032 & $<0.01$ & $<0.001$ \\
\hline $\mathrm{S} 4$ & Rio Bonito & Burned & after rain event & 07/11/2012 & $6: 30$ p.m & 20 & 0.583 & 0.08 & 0.010 \\
\hline $\mathrm{S} 4$ & Rio Bonito & Burned & stable & $04 / 03 / 2013$ & 11:20 a.m. & 0.19 & $<0.010$ & 0.03 & 0.002 \\
\hline $\mathrm{S} 4$ & Rio Bonito & Burned & after rain event & $07 / 23 / 2013$ & 11:45 a.m. & 0.26 & 0.030 & 0.25 & 0.005 \\
\hline $\mathrm{S} 4$ & Rio Bonito & Burned & stable & $11 / 06 / 2013$ & 8:15 a.m. & 0.14 & $<0.010$ & 0.02 & $<0.001$ \\
\hline S5 & Rio Ruidoso & Unburned & after rain event & $07 / 12 / 2012$ & 8:15 a.m. & 1.7 & 0.068 & 0.33 & 0.013 \\
\hline S5 & Rio Ruidoso & Unburned & stable & $04 / 02 / 2013$ & 10:15 a.m. & 0.29 & $<0.010$ & 1.12 & 0.002 \\
\hline S5 & Rio Ruidoso & Unburned & stable & $11 / 05 / 2013$ & 11:15 a.m. & 0.21 & $<0.010$ & 1.93 & 0.003 \\
\hline S6 & Rio Ruidoso & Unburned & after rain event & $07 / 11 / 2012$ & 8:30 a.m. & 1.9 & 0.075 & 0.22 & 0.009 \\
\hline S6 & Rio Ruidoso & Unburned & stable & $04 / 02 / 2013$ & 12:30 p.m. & 0.16 & $<0.010$ & 0.06 & 0.002 \\
\hline S6 & Rio Ruidoso & Unburned & stable & $11 / 05 / 2013$ & 12:45 p.m. & 0.19 & $<0.010$ & 0.29 & 0.003 \\
\hline S7 & Rio Ruidoso & Unburned & after rain event & $07 / 11 / 2012$ & 3:30 p.m. & 0.8 & 0.054 & 0.74 & 0.008 \\
\hline S7 & Rio Ruidoso & Unburned & stable & $04 / 02 / 2013$ & 3:10 p.m. & 0.43 & $<0.010$ & 0.67 & 0.016 \\
\hline S7 & Rio Ruidoso & Unburned & stable & $11 / 05 / 2013$ & 2:30 p.m. & 0.27 & 0.010 & 0.72 & 0.003 \\
\hline S8 & Rio Ruidoso & Partially burned & after rain event & $07 / 11 / 2012$ & 5:40 p.m. & 6.5 & 0.119 & 0.64 & 0.035 \\
\hline S8 & Rio Ruidoso & Partially burned & stable & $04 / 03 / 2013$ & 2:15 p.m. & $<0.07$ & $<0.010$ & 0.13 & $<0.001$ \\
\hline $\mathrm{S} 8$ & Rio Ruidoso & Partially burned & stable & $11 / 06 / 2013$ & 12:45 p.m. & 0.16 & $<0.010$ & 0.12 & 0.001 \\
\hline S9 & Rio Ruidoso & Burned & after rain event & $07 / 11 / 2012$ & 10:34 a.m. & 3.6 & 0.225 & 0.02 & 0.003 \\
\hline S9 & Rio Ruidoso & Burned & after rain event & $07 / 22 / 2013$ & 4:15 p.m. & 1.1 & 0.011 & 1.83 & 0.029 \\
\hline S10 & Rio Hondo & Partially burned & stable & $04 / 03 / 2013$ & $3: 45$ p.m. & 0.12 & 0.011 & 0.42 & 0.002 \\
\hline S10 & Rio Hondo & Partially burned & after rain event & $07 / 23 / 2013$ & 8:30 a.m. & 0.34 & 0.032 & 0.51 & 0.003 \\
\hline $\mathrm{S} 10$ & Rio Hondo & Partially burned & stable & $11 / 06 / 2013$ & 11:00 a.m. & 0.13 & $<0.010$ & 0.27 & $<0.001$ \\
\hline W9 & Rio Bonito & NA & NA & $05 / 08 / 2013$ & 10:10 a.m. & -- & 0.014 & $<0.01$ & $<0.001$ \\
\hline W26 & Rio Ruidoso & NA & NA & $06 / 26 / 2013$ & 5:00 p.m. & -- & 0.012 & 0.94 & 0.006 \\
\hline W35 & Rio Bonito & NA & NA & 05/09/2013 & 12:20 p.m. & -- & $<0.010$ & 0.25 & $<0.001$ \\
\hline W38 & Rio Ruidoso & NA & NA & $06 / 25 / 2013$ & 10:45 a.m. & -- & 0.012 & $<0.01$ & $<0.001$ \\
\hline W39 & Rio Ruidoso & NA & NA & $06 / 24 / 2013$ & $2: 45$ p.m. & -- & 0.011 & 0.14 & $<0.001$ \\
\hline W40 & Rio Bonito & NA & NA & 05/07/2013 & 11:20 a.m. & -- & 0.045 & $<0.01$ & $<0.001$ \\
\hline W41 & Rio Ruidoso & NA & NA & $06 / 25 / 2013$ & 4:30 p.m. & -- & $<0.010$ & 1.06 & $<0.001$ \\
\hline W42 & Rio Bonito & NA & NA & $05 / 09 / 2013$ & 9:50 a.m. & -- & 0.013 & 0.66 & $<0.001$ \\
\hline
\end{tabular}


Table 6. Water-quality data for surface-water and groundwater sites sampled in the upper Rio Hondo Basin, Lincoln County, New Mexico.-Continued

[mm, month; dd, day; yyyy, year; $\mathrm{ft}^{3} / \mathrm{s}$, cubic feet per second; $\mathrm{mg} / \mathrm{L}$, milligrams per liter; --, no data; NA, not applicable; $\mu \mathrm{S} / \mathrm{cm}$ at $25^{\circ} \mathrm{C}$, microsiemens per centimeter at 25 degrees Celsius; ${ }^{\circ} \mathrm{C}$, degrees Celsius; $\mathrm{NTRU}$, nephelometric turbidity ratio unit; $<$, less than; $\mathrm{E}$, estimated; $\mathrm{CaCO}{ }_{3}$, calcium carbonate; $\mathrm{SiO}$, silicon dioxide; +, plus; $\mathrm{N}$, nitrogen; $\mathrm{P}$, phosphorus; $\mu \mathrm{g} / \mathrm{L}$, micrograms per liter]

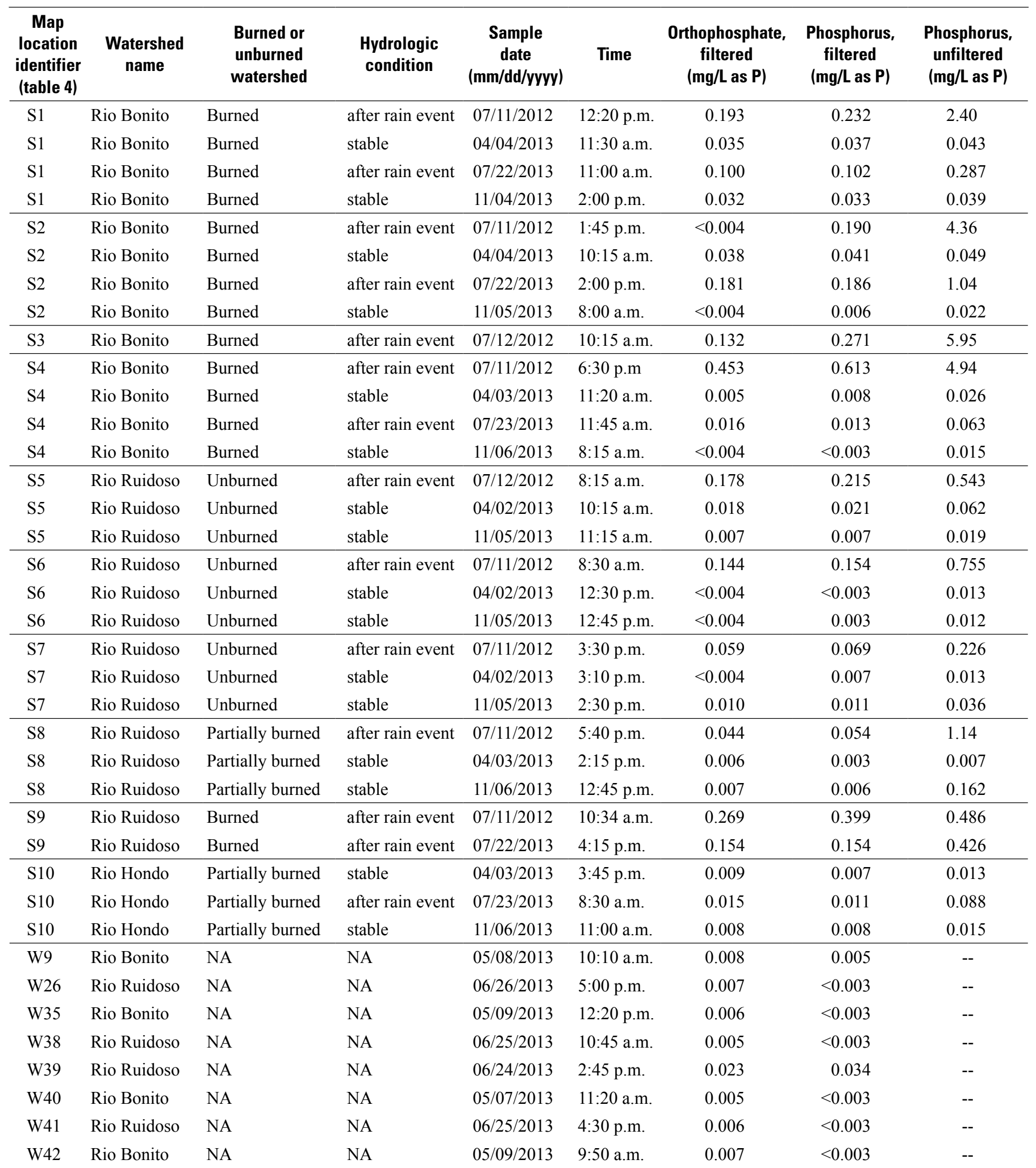




\section{Water Resources During Drought Conditions and Postfire Water Quality in the Upper Rio Hondo Basin, Lincoln County}

Table 6. Water-quality data for surface-water and groundwater sites sampled in the upper Rio Hondo Basin, Lincoln County, New Mexico.-Continued

[mm, month; dd, day; yyyy, year; $\mathrm{ft}^{3} / \mathrm{s}$, cubic feet per second; mg/L, milligrams per liter; --, no data; NA, not applicable; $\mu \mathrm{S} / \mathrm{cm}$ at $25^{\circ} \mathrm{C}$, microsiemens per centimeter at 25 degrees Celsius; ${ }^{\circ} \mathrm{C}$, degrees Celsius; $\mathrm{NTRU}$, nephelometric turbidity ratio unit; <, less than; $\mathrm{E}$, estimated; $\mathrm{CaCO}_{3}, \mathrm{calcium}$ carbonate; $\mathrm{SiO}_{2}$, silicon dioxide; +, plus; $\mathrm{N}$, nitrogen; $\mathrm{P}$, phosphorus; $\mu \mathrm{g} / \mathrm{L}$, micrograms per liter]

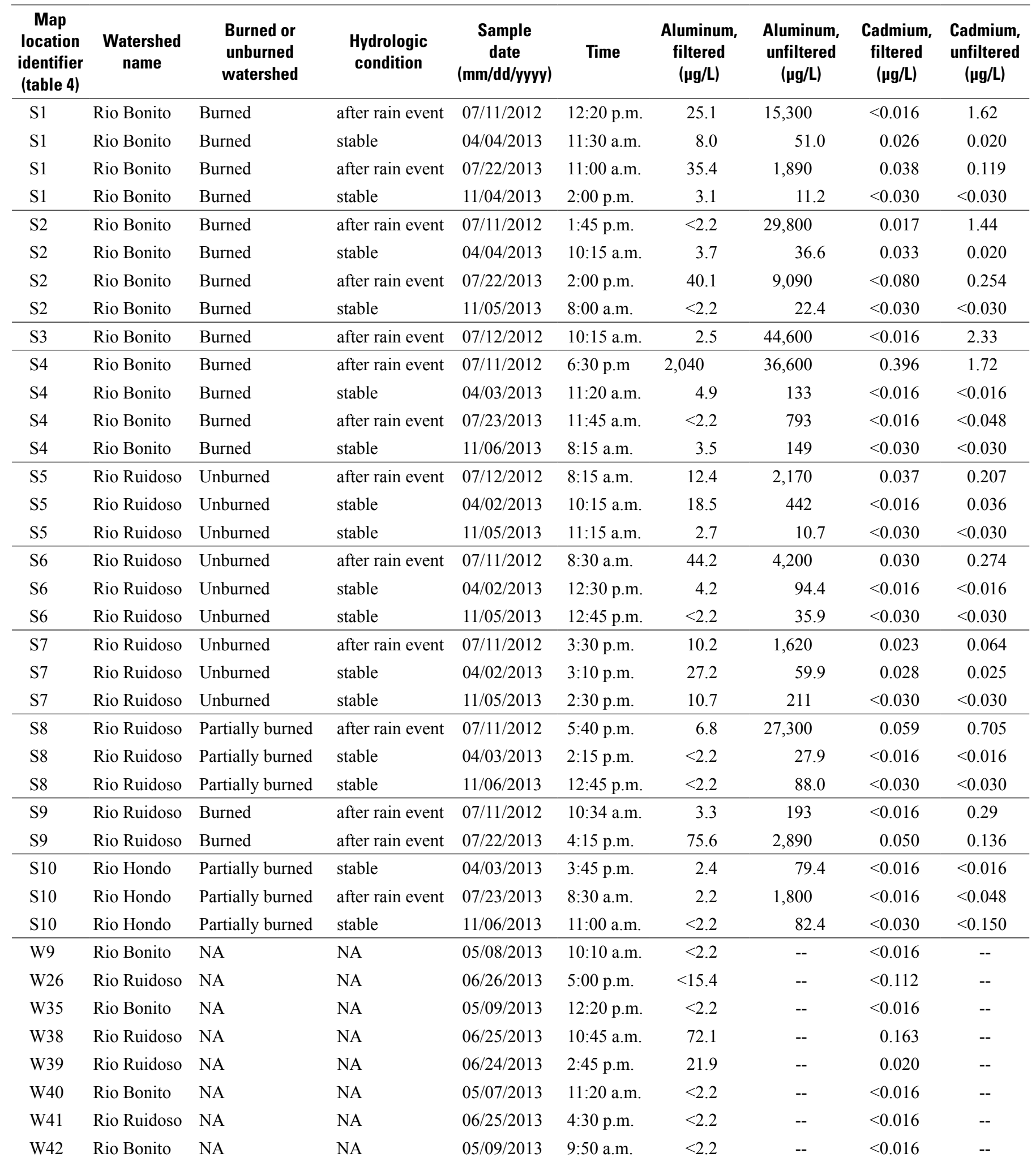


Table 6. Water-quality data for surface-water and groundwater sites sampled in the upper Rio Hondo Basin, Lincoln County, New Mexico.-Continued

[mm, month; dd, day; yyyy, year; $\mathrm{ft}^{3} / \mathrm{s}$, cubic feet per second; $\mathrm{mg} / \mathrm{L}$, milligrams per liter; --, no data; NA, not applicable; $\mu \mathrm{S} / \mathrm{cm}$ at $25^{\circ} \mathrm{C}$, microsiemens per centimeter at 25 degrees Celsius; ${ }^{\circ} \mathrm{C}$, degrees Celsius; $\mathrm{NTRU}$, nephelometric turbidity ratio unit; $<$, less than; $\mathrm{E}$, estimated; $\mathrm{CaCO}{ }_{3}$, calcium carbonate; $\mathrm{SiO}$, silicon dioxide; +, plus; $\mathrm{N}$, nitrogen; $\mathrm{P}$, phosphorus; $\mu \mathrm{g} / \mathrm{L}$, micrograms per liter]

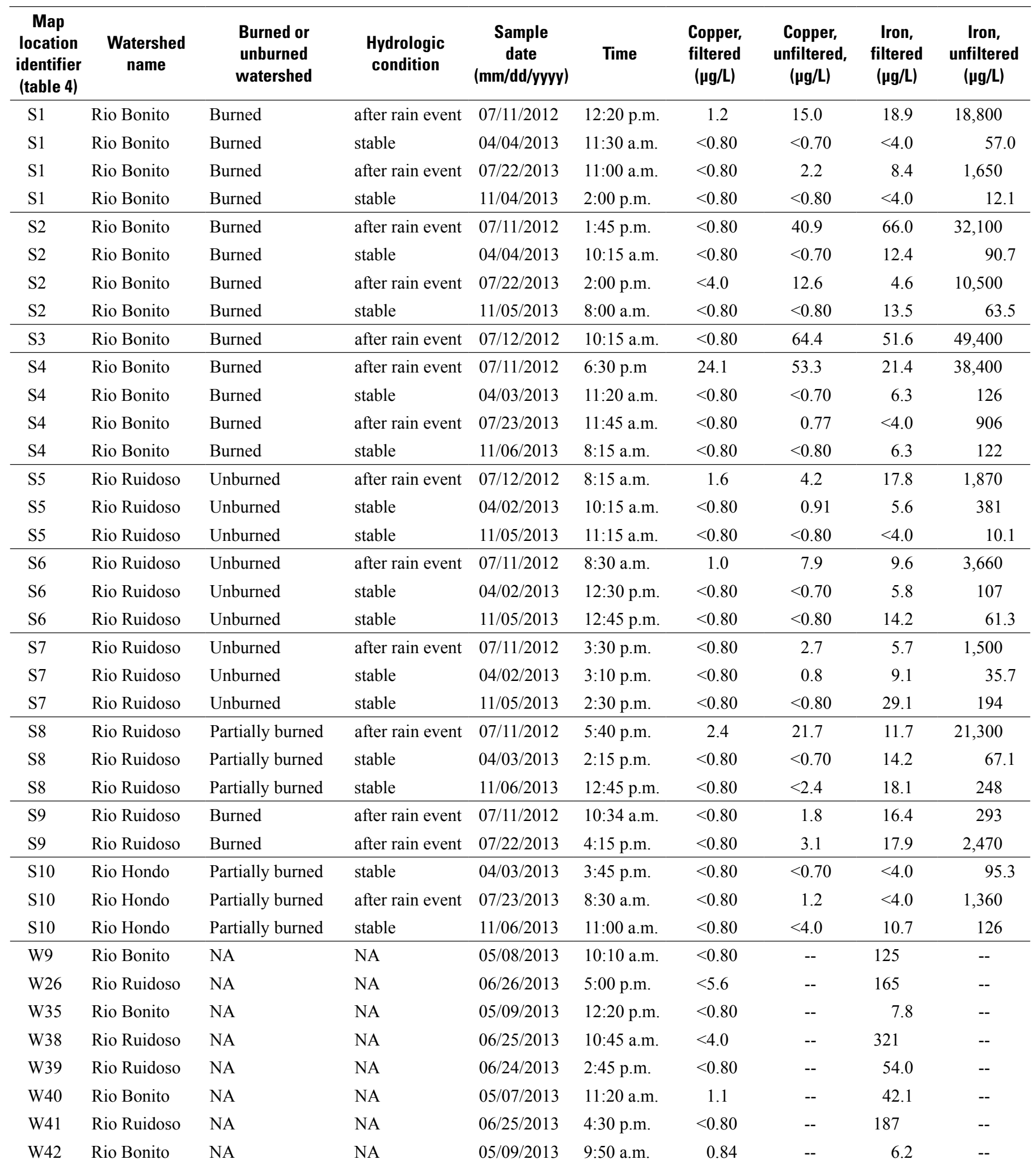




\section{Water Resources During Drought Conditions and Postfire Water Quality in the Upper Rio Hondo Basin, Lincoln County}

Table 6. Water-quality data for surface-water and groundwater sites sampled in the upper Rio Hondo Basin, Lincoln County, New Mexico.-Continued

[mm, month; dd, day; yyyy, year; $\mathrm{ft}^{3} / \mathrm{s}$, cubic feet per second; mg/L, milligrams per liter; --, no data; NA, not applicable; $\mu \mathrm{S} / \mathrm{cm}$ at $25^{\circ} \mathrm{C}$, microsiemens per centimeter at 25 degrees Celsius; ${ }^{\circ} \mathrm{C}$, degrees Celsius; $\mathrm{NTRU}$, nephelometric turbidity ratio unit; <, less than; $\mathrm{E}$, estimated; $\mathrm{CaCO}_{3}, \mathrm{calcium}$ carbonate; $\mathrm{SiO}_{2}$, silicon dioxide; +, plus; $\mathrm{N}$, nitrogen; $\mathrm{P}$, phosphorus; $\mu \mathrm{g} / \mathrm{L}$, micrograms per liter]

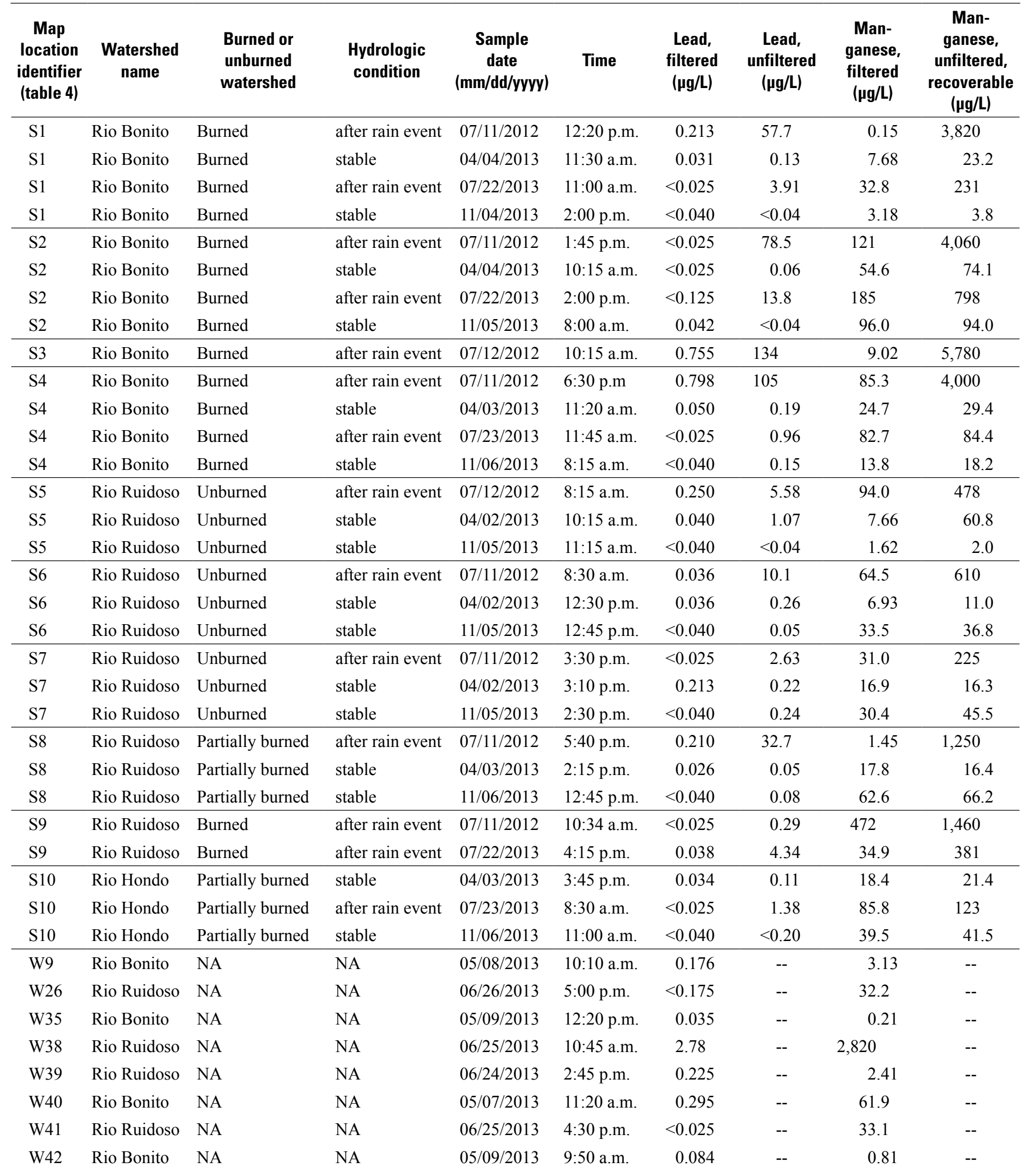


Table 6. Water-quality data for surface-water and groundwater sites sampled in the upper Rio Hondo Basin, Lincoln County, New Mexico.-Continued

[mm, month; dd, day; yyyy, year; $\mathrm{ft} / \mathrm{s}$, cubic feet per second; $\mathrm{mg} / \mathrm{L}$, milligrams per liter; --, no data; NA, not applicable; $\mu \mathrm{S} / \mathrm{cm}$ at $25^{\circ} \mathrm{C}$, microsiemens per centimeter at 25 degrees Celsius; ${ }^{\circ} \mathrm{C}$, degrees Celsius; NTRU, nephelometric turbidity ratio unit; $<$, less than; E, estimated; $\mathrm{CaCO}_{3}$, calcium carbonate; $\mathrm{SiO}_{2}$, silicon dioxide; +, plus; N, nitrogen; P, phosphorus; $\mu \mathrm{g} / \mathrm{L}$, micrograms per liter]

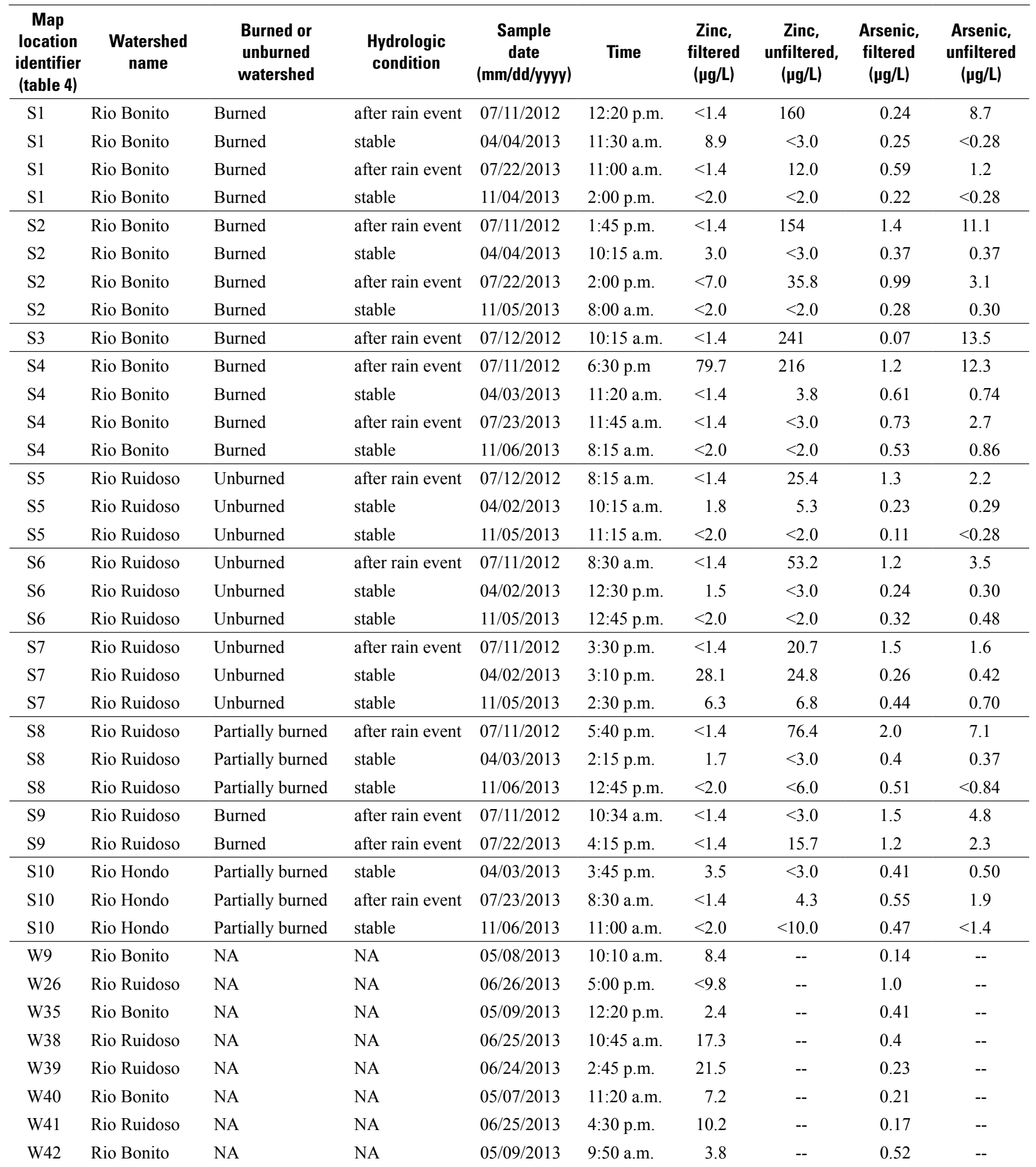




\section{Water Resources During Drought Conditions and Postfire Water Quality in the Upper Rio Hondo Basin, Lincoln County}

Table 6. Water-quality data for surface-water and groundwater sites sampled in the upper Rio Hondo Basin, Lincoln County, New Mexico.-Continued

$\left[\mathrm{mm}\right.$, month; dd, day; yyyy, year; $\mathrm{ft}^{3} / \mathrm{s}$, cubic feet per second; $\mathrm{mg} / \mathrm{L}$, milligrams per liter; --, no data; NA, not applicable; $\mu \mathrm{S} / \mathrm{cm}$ at $25^{\circ} \mathrm{C}$, microsiemens per centimeter at 25 degrees Celsius; ${ }^{\circ} \mathrm{C}$, degrees Celsius; $\mathrm{NTRU}$, nephelometric turbidity ratio unit; <, less than; $\mathrm{E}$, estimated; $\mathrm{CaCO}_{3}, \mathrm{calcium}$ carbonate; $\mathrm{SiO}_{2}$, silicon dioxide; +, plus; $\mathrm{N}$, nitrogen; $\mathrm{P}$, phosphorus; $\mu \mathrm{g} / \mathrm{L}$, micrograms per liter]

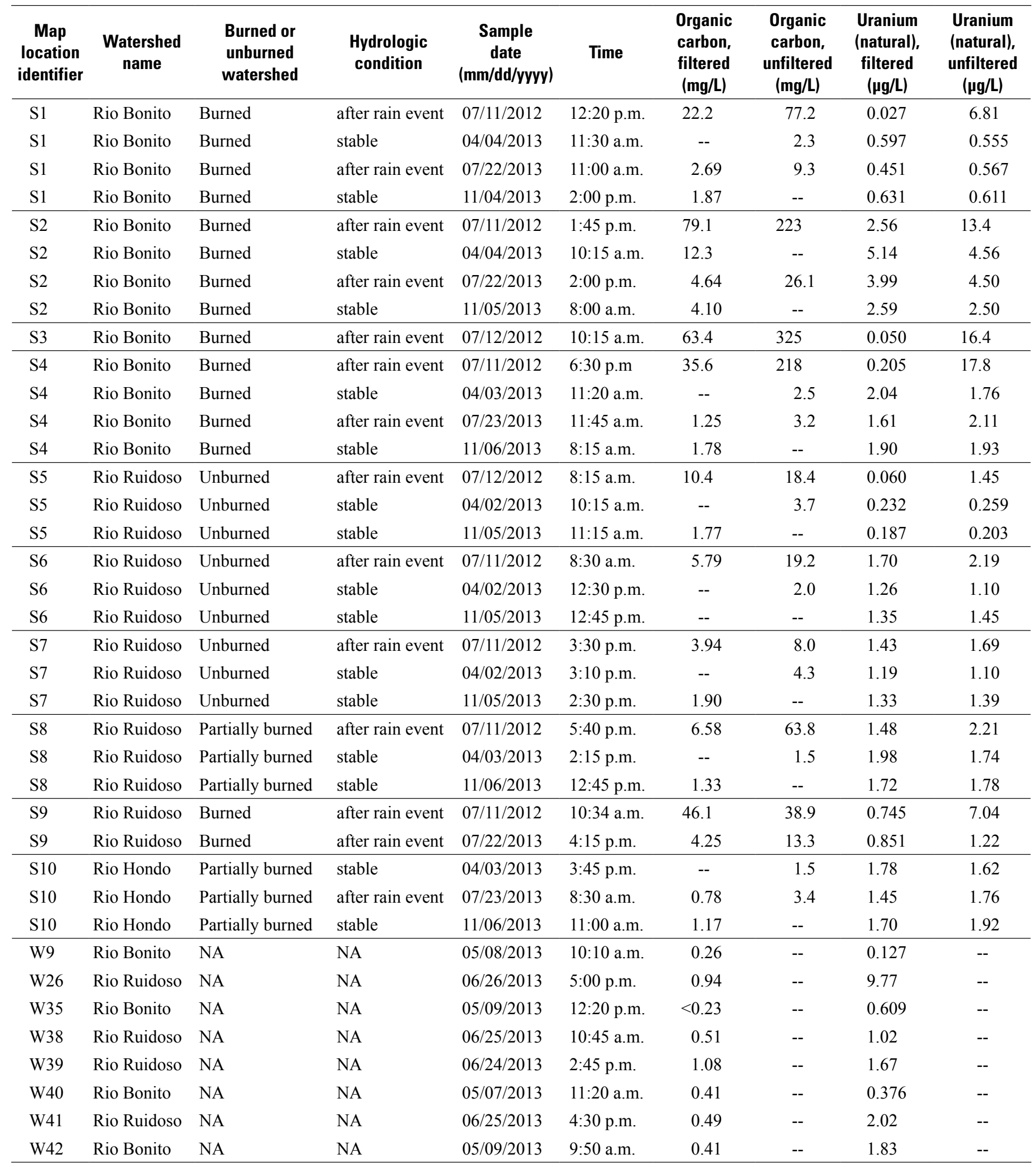




\section{Water Resources During Drought Conditions}

\section{Streamflow}

Streamflow data were collected from two streamflowgaging stations in the upper Rio Hondo Basin: Rio Ruidoso at Hollywood, N. Mex. (08387000; site S6) and Eagle Creek below South Fork near Alto, N. Mex. (08387600; site S9), herein referred to as "Eagle Creek streamflow-gaging station" (fig. 1; table 1). Annual mean streamflow at the Rio Ruidoso at Hollywood streamflow-gaging station (site S6) ranged from 4.17 cubic feet per second $\left(\mathrm{ft}^{3} / \mathrm{s}\right)$ in 1964 to $49.7 \mathrm{ft}^{3} / \mathrm{s}$ in 1987 (fig. $2 C$ ). Average mean annual streamflow for the period of record (1954-2013) is $18.3 \mathrm{ft}^{3} / \mathrm{s}$. The Eagle Creek streamflowgaging station has been operated by the USGS during two periods - 1969-80 and 1988-present (2013). Annual mean streamflow at this station (site $\mathrm{S} 9$ ) ranged from $0.10 \mathrm{ft}^{3} / \mathrm{s}$ in 2011 to $8.48 \mathrm{ft}^{3} / \mathrm{s}$ in 1979 . Average mean annual streamflow for the period of record (1969-80 and 1988-2013) is $2.1 \mathrm{ft}^{3} / \mathrm{s}$ (U.S. Geological Survey, 2014).

Figure $8 A$ shows daily mean streamflow at the Rio Ruidoso at Hollywood streamflow-gaging station (site S6) for the study period (2010-13) along with historical statistics (10th, 50th, and 90th percentiles) for the period of record (1954-2013). The average mean annual streamflow of $18.3 \mathrm{ft}^{3} / \mathrm{s}$ (table 1) was exceeded in $2010\left(31.2 \mathrm{ft}^{3} / \mathrm{s}\right)$ largely because of an above normal snowpack and subsequent spring snowmelt (fig. 4). Annual mean streamflow at site S6 was less than 50 percent of the average mean annual in $2011\left(7.0 \mathrm{ft}^{3} / \mathrm{s}\right.$, 38 percent), $2012\left(6.2 \mathrm{ft}^{3} / \mathrm{s}, 34\right.$ percent $)$, and $2013\left(7.5 \mathrm{ft}^{3} / \mathrm{s}\right.$, 41 percent). A noticeable feature in the streamflow record for 2011-13 at site S6 is that the snowmelt pulse between March 1 and June 1 was diminished compared to the 50thpercentile statistic for the period of record (fig. 8A). At site S6, all 3 years exhibited minimal increases in streamflow during this period, with 2011 and 2013 near the 10th percentile of historical values. Slight increases in streamflow were observed during early April and early May 2012, but daily mean values remained well below the 50th-percentile statistic for the period of record (fig. 8A). Fall and winter (October-February) streamflow values at S6 were near the 50th-percentile statistic for water years 2010, 2011, and 2012 but were lower than the 50th-percentile statistic in 2013. The first zero-streamflow values for the period of record (1954-2013) were recorded at site S6 on June 27-29, 2013.

Figure $8 B$ shows daily mean streamflow at the Eagle Creek streamflow-gaging station (site S9) for the study period (2010-13) along with historical statistics (10th, 50th, and 90th percentiles) for the period of record (1969-80; 1988-2013). Annual mean streamflow at site S9 was above the average mean annual of $2.1 \mathrm{ft}^{3} / \mathrm{s}$ (table 1) in $2010\left(2.7 \mathrm{ft}^{3} / \mathrm{s}\right)$ but below average for water years 2011, 2012, and 2013 (fig. 8B). The lowest annual mean streamflow on record occurred in 2011 $\left(0.10 \mathrm{ft}^{3} / \mathrm{s}\right)$, with the streamflow-gaging station recording zero streamflow for approximately 50 percent of the year (183 days) (U.S. Geological Survey, 2014). Annual mean streamflow values at site S9 in $2012\left(0.15 \mathrm{ft}^{3} / \mathrm{s}\right)$ and 2013 $\left(0.40 \mathrm{ft}^{3} / \mathrm{s}\right)$ were the $3 \mathrm{rd}$ and 8 th lowest on record at this station, respectively. More days of zero streamflow were recorded in 2012 and 2013 (320 and 311 days, respectively) despite higher annual mean values in 2012 and 2013 than 2011.The occurrence of zero streamflow values at the Eagle Creek streamflow-gaging station has increased over time and was not as common during dry periods in the past (Matherne and others, 2010). Some of the rapid increases in streamflow in Eagle Creek in 2012 and 2013 (fig. 8B) were likely the result of monsoon rainfall runoff from burn scar areas because almost the entire drainage area of the gage is within the burn perimeter of the 2012 Little Bear Fire (fig. 6A). The Eagle Creek and Rio Ruidoso at Hollywood streamflow-gaging stations exhibited large ( $>$ 90th percentile) streamflow peaks (fig. 8) that coincided with an extreme rainfall event that occurred from September 10 to September 17, 2013 (4.1 inches at CL1 and 8.5 inches at CL2) (fig. 1; National Oceanic and Atmospheric Administration, National Climatic Data Center, 2014a). 

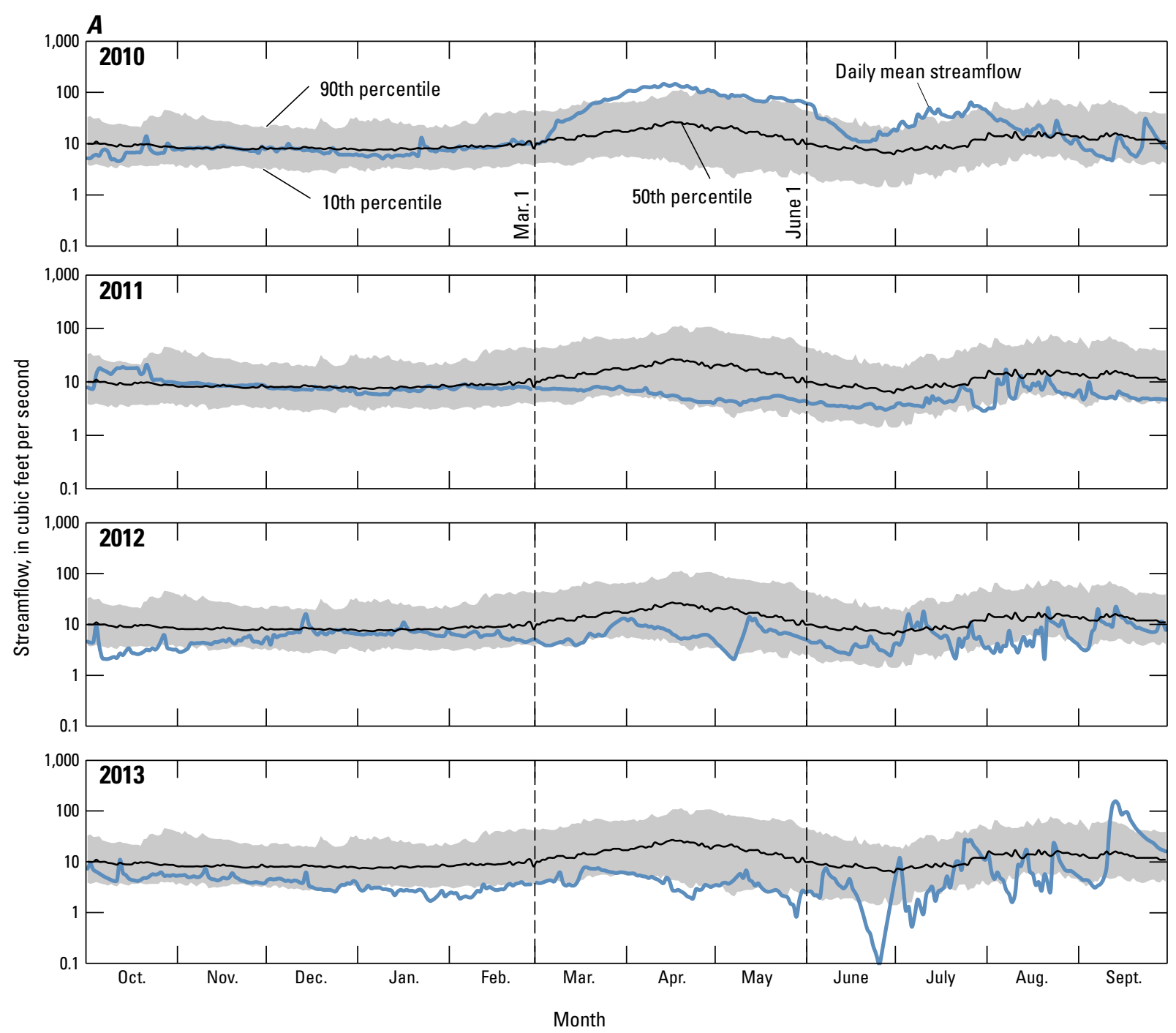

Figure 8. Daily mean streamflow for 2010-13 and selected daily statistics at $A$, Rio Ruidoso at Hollywood, New Mexico (08387000; S6); and $B$, Eagle Creek below Southfork near Alto, N. Mex. (08387000; S9), streamflow-gaging stations. 

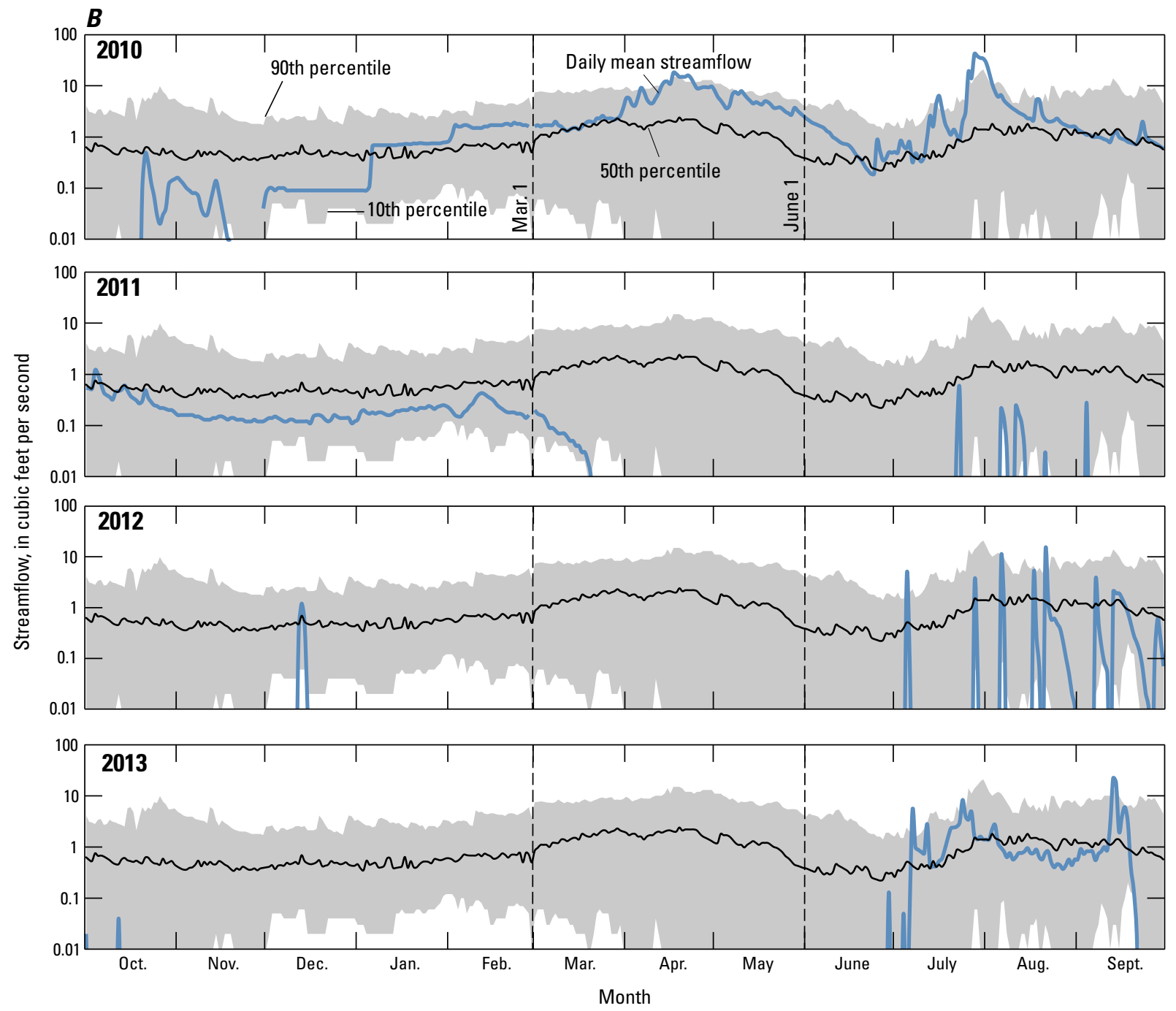

Figure 8. Daily mean streamflow for 2010-13 and selected daily statistics at $A$, Rio Ruidoso at Hollywood, New Mexico (08387000; S6); and $B$, Eagle Creek below Southfork near Alto, N. Mex. (08387000; S9), streamflow-gaging stations.—Continued

Historical total annual precipitation, relative drought conditions, and annual mean streamflow at the Rio Ruidoso at Hollywood streamflow-gaging station are shown in figure 2. Data indicate that annual mean streamflow values (fig. $2 C$ ) observed during 2011-13 drought conditions were of similar magnitude to those measured during the drought of the $1950 \mathrm{~s}$, despite less precipitation (fig. $2 A$ ) and more severe drought conditions (fig. $2 B$ ). Although annual mean streamflow values were similar, spring (March-May) streamflow values from 2011 to 2013 were lower than spring streamflow values observed during the drought of the 1950s when streamflow data were available (1954-56) by about 13 percent, perhaps as a result of a smaller snowpack from 2011 to 2013. The relations of total annual precipitation and annual PDSI to annual mean streamflow at Rio Ruidoso at Hollywood for 1954-2013 are shown in figure 9. Annual mean streamflow values were 7.0, 6.2, and $7.5 \mathrm{ft}^{3} / \mathrm{s}$ in 2011, 2012, and 2013, respectively. Although these streamflow values were not the lowest on record, they were under the 15 th percentile for the period of record.

Increases in the number and magnitude of large flow events at the Eagle Creek streamflow-gaging station (site S9), located downstream from a burned watershed, were observed after the occurrence of the Little Bear Fire in 2012 (fig. 8B), but annual mean streamflow remained below average for 2012 and 2013 (fig. 2C). In general, periodic increases in streamflow related to snowmelt or monsoon rain events were observed at both the Rio Ruidoso at Hollywood (fig. $8 A$ ) and Eagle Creek (fig. $8 B$ ) streamflow-gaging stations during the study period (2010-13), but these increases overlay a longerterm trend of decreasing annual streamflow in the Rio Ruidoso watershed since the 1980s (fig. 2C). 

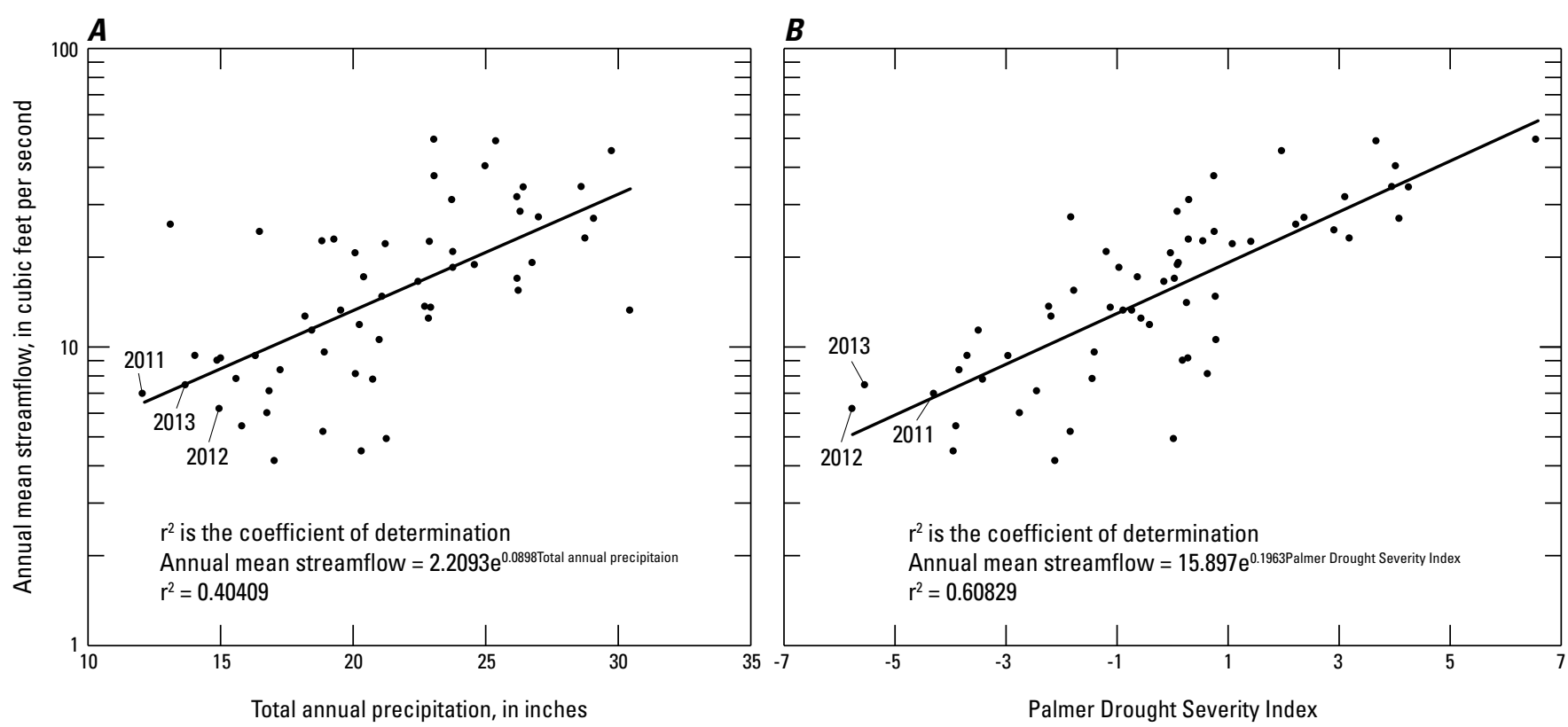

Figure 9. Relation between Rio Ruidoso at Hollywood, New Mexico (08387000; S6) streamflow-gaging station annual mean streamflow and $A$, Ruidoso, New Mexico, climate station total annual precipitation; and $B$, Palmer Drought Severity Index, New Mexico Climate Division 6, 1954-2013.

\section{Groundwater Levels}

\section{Discrete Groundwater-Level Measurements}

The USGS monitored groundwater levels in the upper Rio Hondo Basin approximately bimonthly in 37 wells between 2010 and 2013. Rises or declines in groundwater levels collected during 2010-13 were determined by calculating the difference in water levels from September 2009 to September 2013. Water-level declines were observed in 34 wells, water-level rises were observed in 2 wells (W12 and W13), and 2 wells had no change in water level (W19 and W33). The average water-level change among all 37 wells was $-7.6 \mathrm{ft}$ with several wells exhibiting declines of more than $25 \mathrm{ft}$ (W17, W24, and W29) (fig. 10; table 3). The largest water-level declines were observed in the upper reaches of the Rio Bonito and Rio Ruidoso watersheds, coincident with the highest population density in the upper Rio Hondo Basin (Darr and others, 2014), and smaller declines were observed in the lower reaches of the watersheds. Both of the wells that exhibited water-level rises are located along the Rio Bonito.

Normalized hydrographs (explained in the "Methods" section) from selected wells are shown in figure 11. Water levels from 10 wells located in Rio Ruidoso watershed (fig. $11 A$ ) and 12 wells located in the Rio Bonito watershed (fig. 11B) exhibited mostly above-average water levels in early 2011 and mostly below-average water levels from 2011 to 2013. Most water levels were relatively stable or slightly increasing from 2010 to 2011 and exhibited a decline from 2011 to 2013. No obvious change in water levels was observed in the Rio Bonito watershed (fig. 11B) after the occurrence of the Little Bear Fire in June.

Decadal-scale water-level changes were observed (Darr and others, 2014) to be coincident with precipitation patterns in which average water-level changes in the upper Rio Hondo Basin varied from $+4.0 \mathrm{ft}$ to $-17.0 \mathrm{ft}$. Water levels were relatively lower in the $1950 \mathrm{~s}$, higher in the late $1980 \mathrm{~s}$ and early 1990s, lower in 2003, and higher in 2010. Longterm water-level changes were also reported on the order of $\pm 4 \mathrm{ft}$ when comparing conditions in the 1950 s to those in 2003 (Donohoe, 2004), two time periods exhibiting drought conditions. Donohoe (2004) also observed water-level declines of as much as $50 \mathrm{ft}$ in 52 of the 61 wells measured between March 2003 and July 2003. These water-level changes were likely affected by localized and seasonal groundwater withdrawals. Basinwide comparisons between water levels measured during the 1950s, 2003, and 2011-13 drought conditions were not feasible for this report because only four wells have a historical record with measurements during all three of these periods (W1, W19, W25, and W32) (table 3). In general, water-level changes observed from 2010 to 2013, in which a majority of the change occurred during drought conditions from 2011 to 2013, were on the order of decadalscale changes that previously have been observed in the upper Rio Hondo Basin (Darr and others, 2014). 


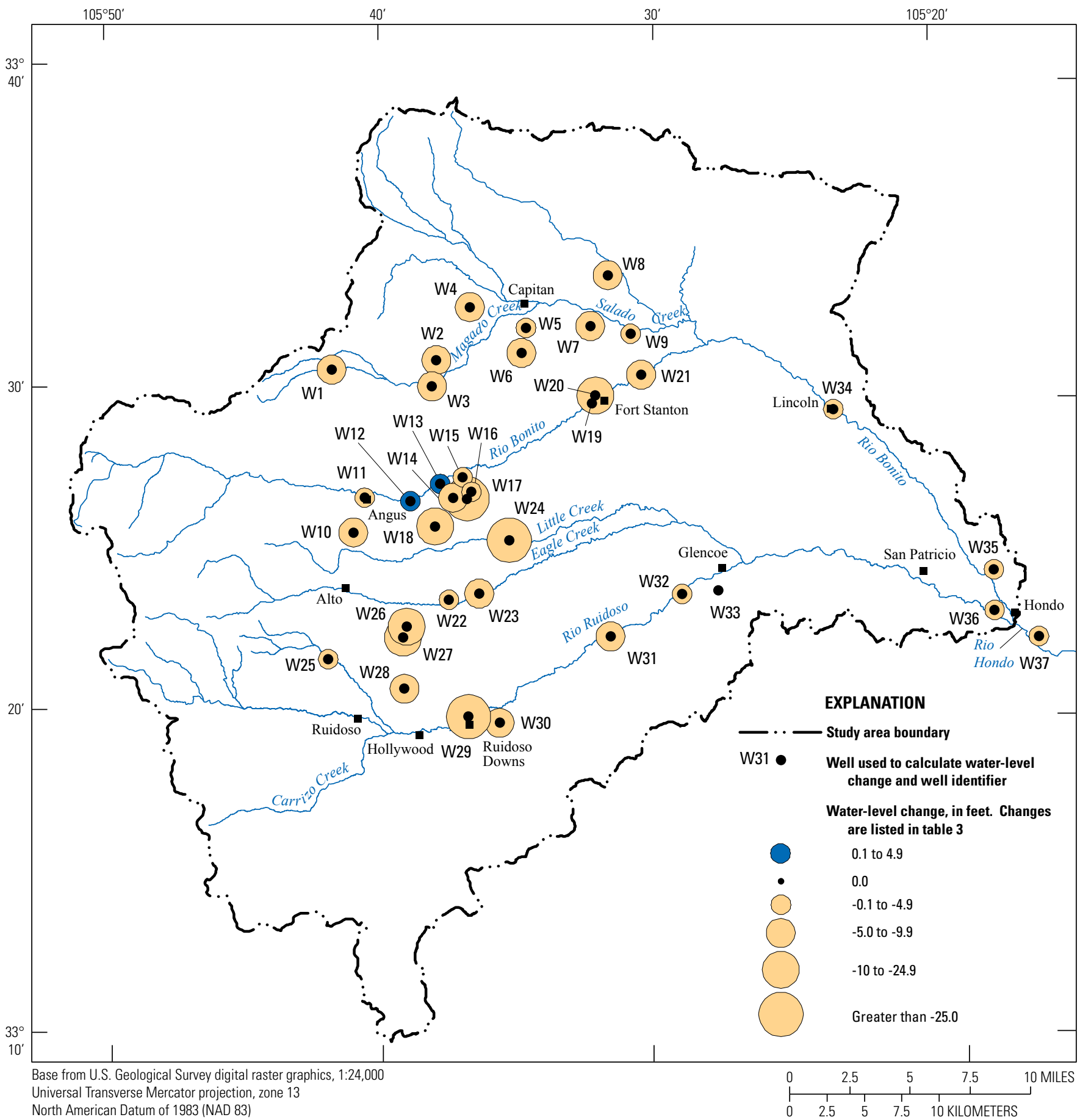

Figure 10. Water-level changes in 37 wells from 2010 to 2013, upper Rio Hondo Basin, Lincoln County, New Mexico. 


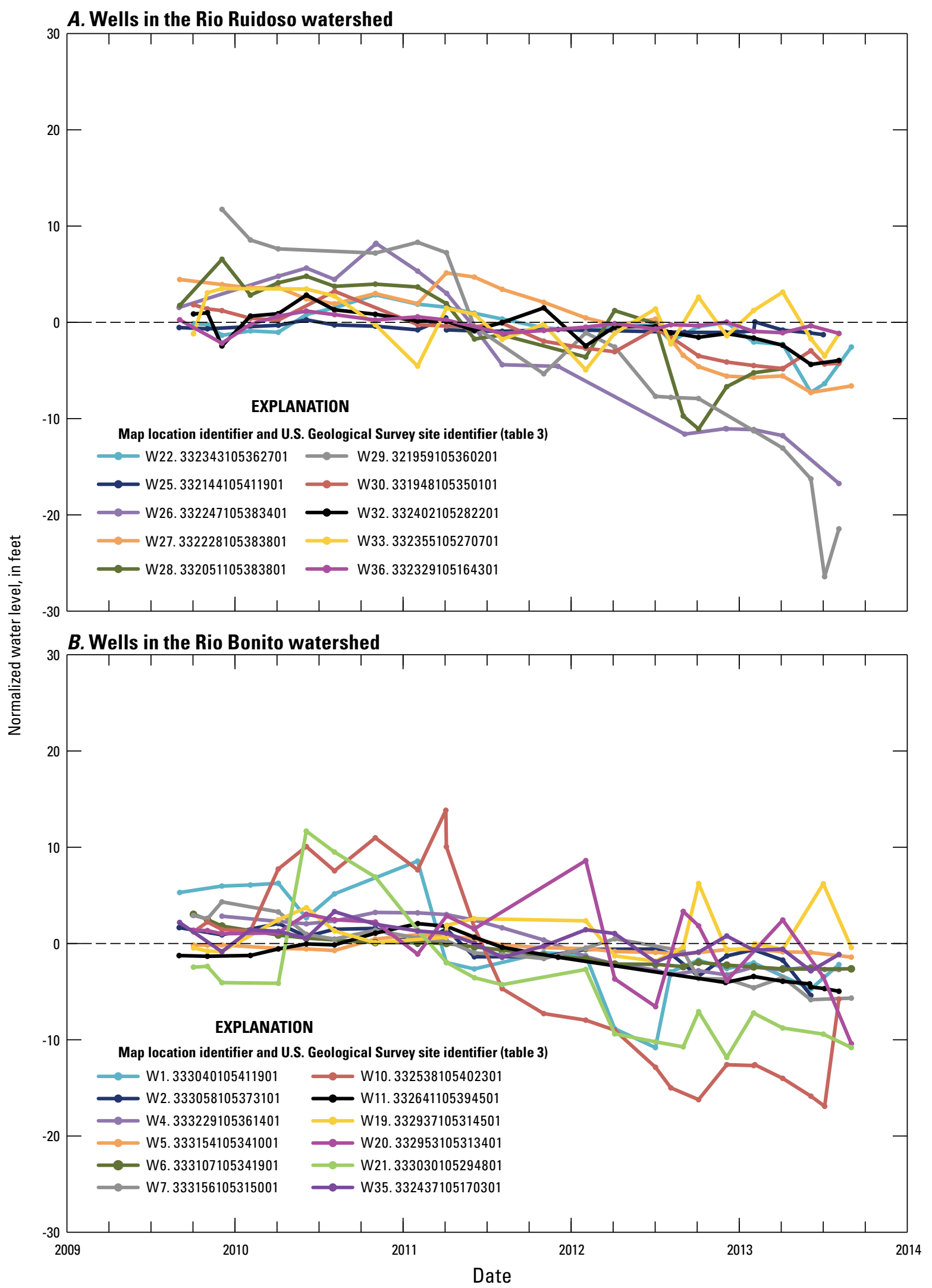

Figure 11. Selected wells in the $A$, Rio Ruidoso watershed; and $B$, the Rio Bonito watershed from 2010 to 2013, upper Rio Hondo Basin, Lincoln County, New Mexico. 


\section{Continuous Groundwater-Level Measurements}

Changes in groundwater levels occur on various time scales, and rapid fluctuations resulting from precipitation events can go undetected by measurements on a bimonthly time scale. Hydrographs from three wells equipped with continuous water-level recorders since 2008 are shown in figure 12. Groundwater-level declines were observed from January 2011 to summer 2013 in wells W11 (fig. 12A) and W26 (fig. 12C) that are consistent with declines in bimonthly water-level measurements ( $7 \mathrm{ft}$ and $22 \mathrm{ft}$, respectively) (fig. 11 $A$ and 11B). However, well W25 (fig. 12B) did not exhibit a noticeable groundwater-level decline over the same time period. Well W26 is completed in the Permian regional aquifer system, while wells W11 and W25 are completed in Cretaceous sandstones or shales (Rawling, 2011; Darr and others, 2014). Although well W25 is completed in similar geology to well W11 (Cretaceous sandstones or shales), it exhibits faster response time to events and diurnal behavior consistent with a closer hydraulic connection to surface water at this location. In addition, the western part of the upper Rio Hondo Basin where W25 is located is highly fractured and faulted, and as a result, groundwater movement and response to pumping and precipitation events can vary substantially over small distances and depths. This is illustrated by highly variable well production in similar geologic units (Darr and others, 2014).

All three sites exhibited water-level increases beginning in September 2013 in response to an extreme rainfall event that occurred in the upper Rio Hondo Basin from September 10 to September 17, 2013. After this event, water-level increases in wells equipped with continuous water-level
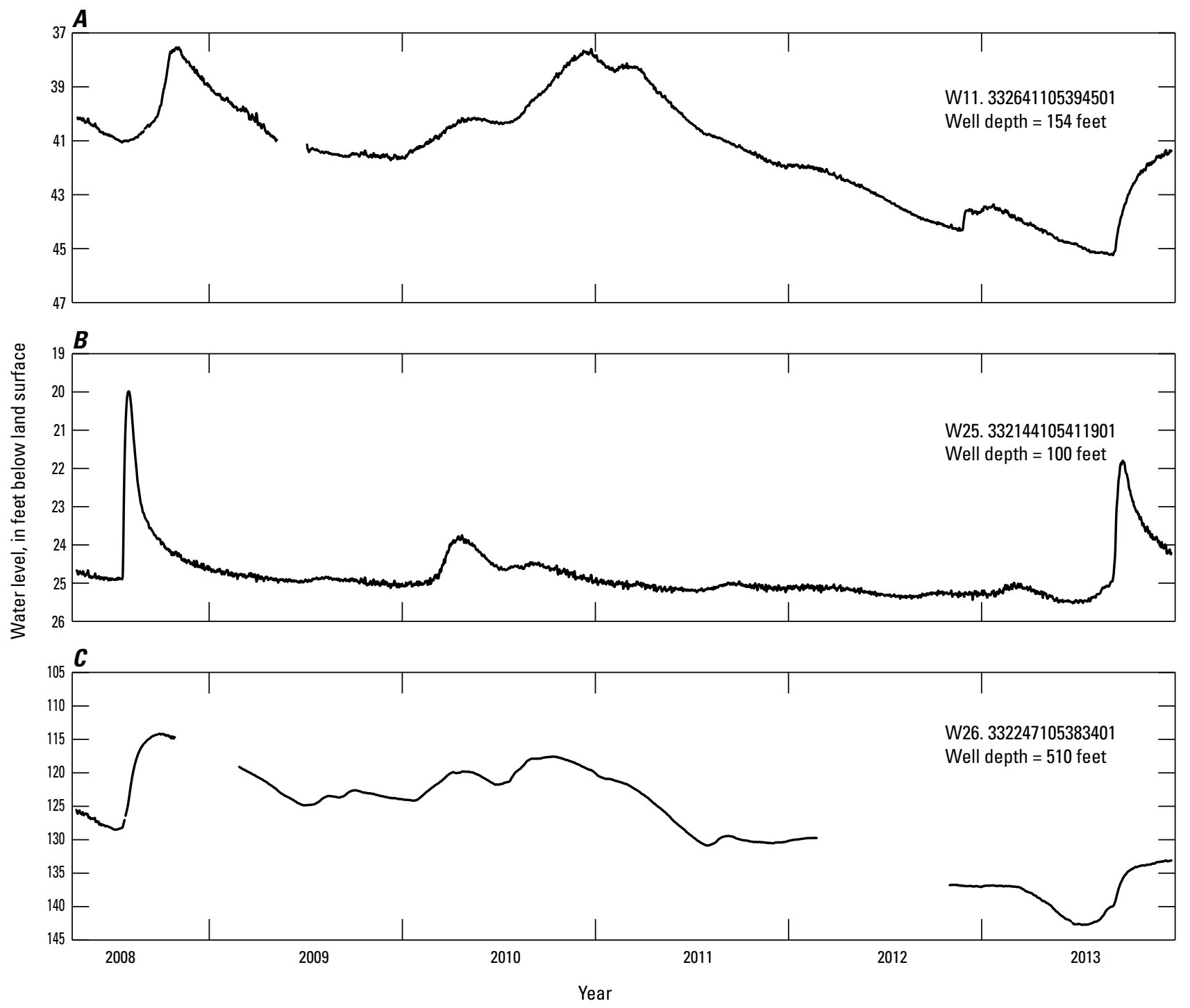

Figure 12. Wells with continuous water-level recorders in the upper Rio Hondo Basin, Lincoln County, New Mexico. 
recorders ranged from about $4 \mathrm{ft}$ in wells W11 (fig. 12A) and W25 (fig. 12B) to about $10 \mathrm{ft}$ in well W26 (fig. 12C) and began almost instantaneously (increases in all three wells began before September 17). These water-level increases are of similar orders of magnitude to observed increases in other wells in response to historical precipitation events in the upper Rio Hondo Basin (Donohoe, 2004; Matherne and others, 2010) and outside of the study area in the Sacramento Mountains (Newton and others, 2012).

Darr and others (2014) also documented responses to weather related events in wells W11, W25, and W26 from 2008 to 2010, making note of water-level increases in response to heavy precipitation as a result of Hurricane Dolly in 2008 and an above-average snowmelt in 2010. Although water levels increased in wells W11 and W26 at the end of 2013, water levels remained near or below minimum values observed during 2008-11 (figs. 12A and 12C). The recharge pulse observed in well W25 beginning in September 2013 begins to decline by the end of 2013, indicating that these event-based recharge pulses are temporary in this location.

Surface-water diversions and groundwater withdrawals have increased over time in the upper Rio Hondo Basin (Darr and others, 2014) and may increase further during persistent drought conditions. It is likely that increases in surface-water diversions and (or) groundwater pumping have contributed to declining streamflow and groundwater levels in the upper Rio Hondo Basin, but their effects are difficult to differentiate from the effects of drought conditions. Regardless of the magnitude of the influences of surface-water diversions and groundwater pumping on current streamflow and groundwater-level conditions, a reduction in precipitation and worsening drought conditions may lead to increased reliance on groundwater for public supply and cause further strain on the water resources of the upper Rio Hondo Basin.

\section{Determination of Recharge Mechanisms}

\section{Stable Isotope Results}

Seven surface-water samples, four spring samples, and nine groundwater well samples were collected between May and November 2013 and analyzed for $\delta \mathrm{D}$ and $\delta^{18} \mathrm{O}$. Values of $\delta$ D ranged from -68.4 to -57.6 per mil and values of $\delta^{18} \mathrm{O}$ ranged from -10.0 to -8.2 per mil for surface-water samples. Values of $\delta \mathrm{D}$ ranged from -70.4 to -53.9 per mil and values of $\delta^{18} \mathrm{O}$ ranged from -10.3 to -7.9 per mil for spring samples. Values of $\delta \mathrm{D}$ ranged from -70.1 to -53.0 per mil and values of $\delta^{18} \mathrm{O}$ ranged from -10.5 to -7.5 per mil for groundwater samples (fig. 13A, table 7). The similar isotope composition of the three types of samples (surface water, springs, and wells) suggests an interaction between surface water and groundwater, at least in areas near streams.

Samples for this study were collected from sites with land-surface elevations ranging from $5,184 \mathrm{ft}$ to $9,816 \mathrm{ft}$, representing a majority of the elevation range in the upper Rio Hondo Basin. Sample values for $\delta \mathrm{D}$ exhibit a correlation with elevation based on linear regression methods (Helsel and Hirsch, 2002) with the heaviest (least negative) samples associated with lower elevations and the lightest (most negative) samples associated with higher elevation samples (fig. 13B). A similar correlation was seen with $\delta^{18} \mathrm{O}$ but is not presented in a figure. The gradient was due to elevation change and was seen in $\delta \mathrm{D}$ as -3.7 per mil every $1,000 \mathrm{ft}$ of elevation increase and in $\delta^{18} \mathrm{O}$ as -0.06 per mil every $1,000 \mathrm{ft}$ of elevation increase. These rates of change are lower than a range of other gradients reported from mountainous terrains around the world (Vuataz and Goff, 1986) but are similar to gradients from precipitation in the southern Sacramento Mountains (Newton and others, 2012; Eastoe and Rodney, 2014).

The stable isotope values are plotted in figure $13 \mathrm{~A}$ and are compared to the GMWL and two regional water lines: the LMWL from Newton and others (2012) and the Sacramento Mountains Trend (SMT) from Eastoe and Rodney (2014). The LMWL represents the relation between $\delta \mathrm{D}$ and $\delta^{18} \mathrm{O}$ in precipitation collected from the Sacramento Mountains to the south of the study area. The SMT is a relation developed from the stable isotope values from surface water, springs, and groundwater wells in the higher elevations (approximately 5,300-8,500 ft) of the Sacramento Mountains. The LMWL plots above the GMWL but with a similar slope of 8.4 compared to 8 for the GMWL. The SMT has a lower slope of 6.1, which is attributed to an evaporation trend on water with an initial winter precipitation signature (Eastoe and Rodney, 2014). The data collected for this study fall outside the LMWL typical summer precipitation in the Sacramento Mountains (with $\delta \mathrm{D}$ and $\delta^{18} \mathrm{O}$ values above approximately -67 and -11 , respectively) and correspond well to the slope of the SMT (Newton and others, 2012) (fig. 13A), which would be consistent with the relatively heavy stable isotopic compositions of water samples from lower elevations largely being the result of evaporation of precipitation that originated at higher elevations.

The LMWL was developed during a time when two anomalous summer precipitation seasons (2006 and 2008) occurred (Matherne and others, 2010), which may have skewed the volume-weighted LMWL line away from the long-term average composition for the area; therefore, this line may not be ideal for comparisons to values from the upper Rio Hondo Basin, especially during abnormally dry periods. Newton and others (2012) observed that seasonal stable isotope values of surface water, springs, and groundwater wells varied in response to the large summer recharge events that occurred in 2006 and 2008. Samples collected after the recharge events plot closer to the LMWL, then shift over time back to a trend more similar to the SMT. Samples collected for this study were not coincident with any large recharge events, and values plot close to the SMT (fig. 13A). 


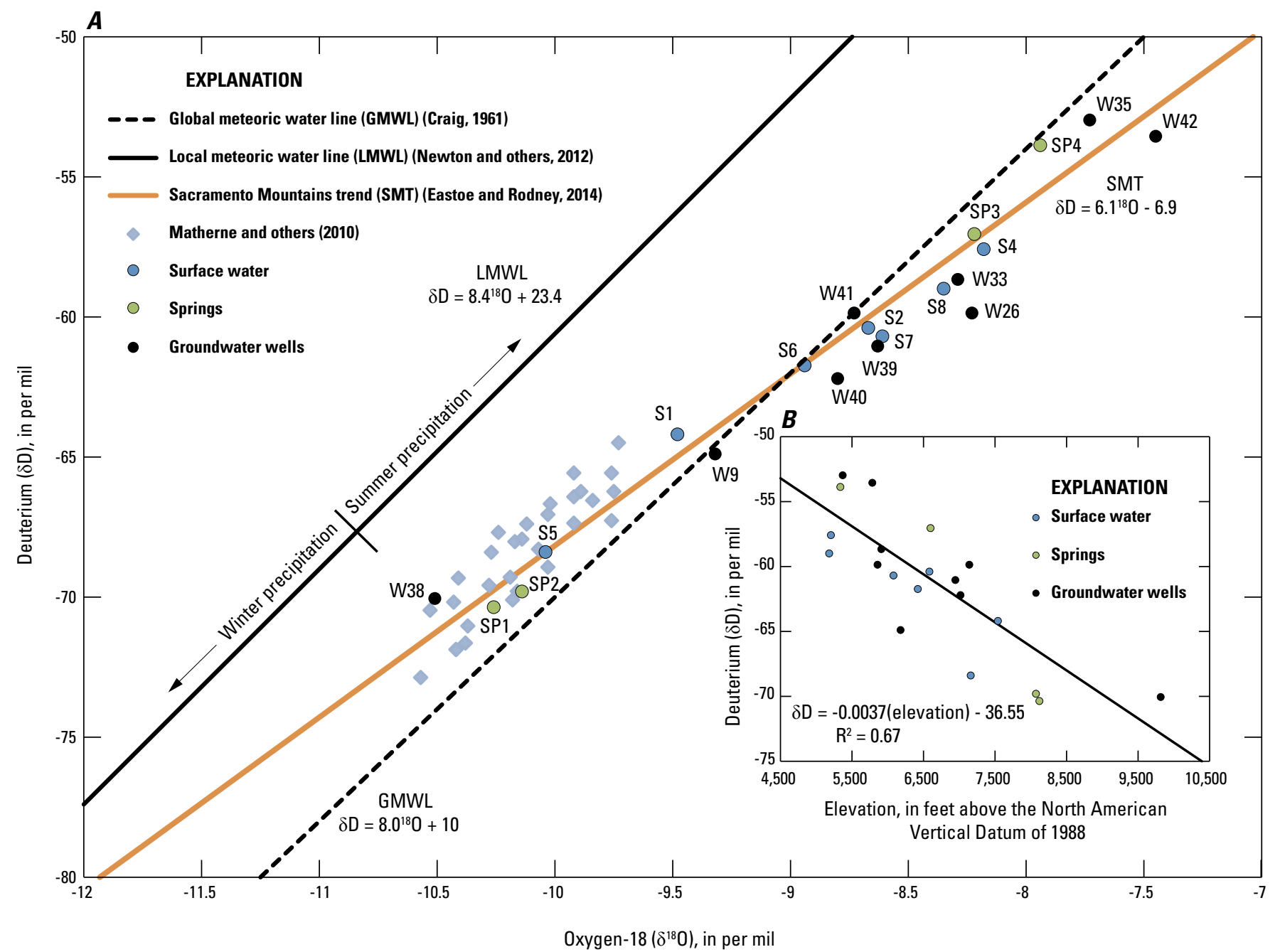

Figure 13. $A$, Stable isotopes deuterium $(\delta \mathrm{D})$ and oxygen-18 $\left(\delta^{18} 0\right)$ expressed as the deviation $(\delta)$, in parts per thousand, from Standard Mean Ocean Water (Craig, 1961); and B, Deuterium values with respect to site land-surface elevation in surface-water, groundwater, and spring samples collected in the upper Rio Hondo Basin, Lincoln County, New Mexico.

Stable isotope results from groundwater samples collected in upper Eagle Creek in 2008 and 2009 by Matherne and others (2010) fall largely near the SMT but with a best-fit line similar to that of the LMWL (slope 7.8). This difference in slope compared to the samples from this study and the SMT are likely the result of the influence of the large July 2008 summer precipitation event associated with the remnants of Hurricane Dolly. As was seen in the samples collected for the Newton and others (2012) investigation, samples collected after these large summer precipitation events skew towards the LMWL, only to later trend back towards the SMT. Samples from the Matherne and others (2010) study in upper Eagle Creek are more depleted in $\delta \mathrm{D}$ and $\delta^{18} \mathrm{O}$ than the samples from this study, likely because of the effect of higher elevation, as samples for the Matherne and others (2010) study were from an elevation of about 7,800 ft compared to about $6,600 \mathrm{ft}$ for this study. The depletion effects of rainout from the large precipitation event in July 2008 also likely play a role in the composition of these samples.

Deviation of isotope values along the evaporation trend represented by the SMT indicates that rather than rapid recharge into aquifers some component of groundwater recharge (particularly at lower elevations) is being evaporated first, perhaps within shallow alluvial stream channels or by repeated cycles of stream water exiting and entering the alluvial materials of streambanks along gaining and losing stream reaches, referred to as "daylighting and diving" (Matherne and others, 2010; Newton and others, 2012). Repeated gaining and losing streamflow reaches are common in the area and have been observed on upper Eagle Creek (Matherne and others, 2010) and other streams in the upper Rio Hondo Basin (Darr and others, 2014). Isotope values further along the SMT (heavier values; less negative) indicate repeated evaporation events, and the general presence of the 


\section{Water Resources During Drought Conditions and Postfire Water Quality in the Upper Rio Hondo Basin, Lincoln County}

Table 7. Isotope data for sites sampled in the upper Rio Hondo Basin, Lincoln County, New Mexico.

$\left[\mathrm{mm}\right.$, month; dd, day; yyyy, year; $\delta \mathrm{D}$, Deuterium/Protium ratio; $\delta^{18} \mathrm{O}$, delta Oxygen-18; TU, tritium units; $\delta^{13} \mathrm{C}$, delta Carbon-13; ${ }^{14} \mathrm{C}$, Carbon-14; NS, not sampled]

\begin{tabular}{|c|c|c|c|c|c|c|c|c|c|}
\hline $\begin{array}{c}\text { Map } \\
\text { location } \\
\text { identifier } \\
\text { (table 3) }\end{array}$ & $\begin{array}{l}\text { Land-surface } \\
\text { elevation } \\
\text { above North } \\
\text { American } \\
\text { Vertical } \\
\text { Datum of } 1988 \\
\text { (feet) }\end{array}$ & $\begin{array}{c}\text { Sample } \\
\text { date } \\
\text { (mm/dd/yyyy) }\end{array}$ & $\begin{array}{c}\delta \mathbf{D} \\
\text { (per mil) }\end{array}$ & $\begin{array}{c}\delta^{18} \mathbf{0} \\
\text { (per mil) }\end{array}$ & $\begin{array}{l}\text { Tritium } \\
\text { (TU)' }\end{array}$ & $\begin{array}{c}\delta^{13} \mathbf{C} \\
\text { (per mil) }\end{array}$ & $\begin{array}{c}{ }^{14} \mathrm{C} \\
\text { (percent } \\
\text { modern) }\end{array}$ & $\begin{array}{l}{ }^{14} \mathrm{C} \\
\text { (percent } \\
\text { modern } \\
\text { carbon) }\end{array}$ & $\begin{array}{c}\text { Unadjusted } \\
\text { radiocarbon } \\
\text { age } \\
\text { (years) }\end{array}$ \\
\hline \multicolumn{10}{|c|}{ Surface water } \\
\hline S1 & 7,540 & $11 / 04 / 2013$ & -64.2 & -9.5 & $\mathrm{NS}^{2}$ & NS & NS & NS & NS \\
\hline $\mathrm{S} 2$ & 6,582 & $11 / 05 / 2013$ & -60.4 & -8.7 & NS & NS & NS & NS & NS \\
\hline S4 & 5,207 & $11 / 06 / 2013$ & -57.6 & -8.2 & NS & NS & NS & NS & NS \\
\hline S5 & 7,163 & $11 / 05 / 2013$ & -68.4 & -10.0 & NS & NS & NS & NS & NS \\
\hline S6 & 6,422 & $11 / 05 / 2013$ & -61.7 & -8.9 & NS & NS & NS & NS & NS \\
\hline S7 & 6,080 & $11 / 05 / 2013$ & -60.7 & -8.6 & NS & NS & NS & NS & NS \\
\hline S8 & 5,184 & $11 / 06 / 2013$ & -59.0 & -8.4 & NS & NS & NS & NS & NS \\
\hline \multicolumn{10}{|c|}{ Springs } \\
\hline SP1 & 8,120 & $11 / 08 / 2013$ & -70.4 & -10.3 & NS & NS & NS & NS & NS \\
\hline SP2 & 8,072 & $11 / 07 / 2013$ & -69.8 & -10.1 & NS & NS & NS & NS & NS \\
\hline SP3 & 6,598 & $11 / 07 / 2013$ & -57.0 & -8.2 & NS & NS & NS & NS & NS \\
\hline SP4 & 5,337 & $11 / 07 / 2013$ & -53.9 & -7.9 & NS & NS & NS & NS & NS \\
\hline \multicolumn{10}{|c|}{ Groundwater } \\
\hline W9 & 6,181 & $05 / 08 / 2013$ & -64.9 & -9.3 & ${ }^{1} 0.07$ & -8.0 & 32.7 & 33.9 & $8,644.3$ \\
\hline W26 & 7,143 & $06 / 26 / 2013$ & -59.9 & -8.2 & 2.5 & -10.9 & 39.9 & 41.1 & $7,093.6$ \\
\hline W33 & 5,912 & $11 / 07 / 2013$ & -58.7 & -8.3 & NS & NS & NS & NS & NS \\
\hline W35 & 5,372 & $05 / 09 / 2013$ & -53.0 & -7.7 & ${ }^{2} 0.05$ & -13.2 & 49.8 & 51.0 & $5,350.1$ \\
\hline W38 & 9,816 & $06 / 25 / 2013$ & -70.1 & -10.5 & 3.1 & -14.6 & 72.0 & 73.6 & $2,410.3$ \\
\hline W39 & 6,945 & $06 / 24 / 2013$ & -61.0 & -8.6 & NS & NS & NS & NS & NS \\
\hline W40 & 7,017 & $05 / 07 / 2013$ & -62.2 & -8.8 & 1.0 & -6.1 & 31.0 & 32.2 & $9,053.4$ \\
\hline W41 & 5,857 & $06 / 25 / 2013$ & -59.9 & -8.7 & 1.8 & -10.8 & 65.8 & 67.7 & $3,072.0$ \\
\hline W42 & 5,784 & 05/09/2013 & -53.6 & -7.5 & 0.3 & -7.9 & 44.0 & 45.6 & $6,258.0$ \\
\hline
\end{tabular}

${ }^{1}$ Below laboratory detection limit of $0.09 \mathrm{TU}$.

${ }^{2}$ Below laboratory detection limit of $0.08 \mathrm{TU}$.

lowest-elevation samples on the distal end of this evaporative trend line supports this because low-elevation samples have more opportunities for daylighting and evaporation. Conversely, values nearer to the intersection of the LMWL and SMT correspond to depleted waters, likely winter precipitation (snowmelt), that were subjected to less evaporation. The SMT intersects the LMWL near an isotope composition similar to winter precipitation at a site located at an elevation of about 9,150 ft based on a relation between elevation and isotopic composition of precipitation (Eastoe and Rodney, 2014).

Stable-isotope data from this study and others from the Sacramento Mountains to the south of the upper Rio Hondo Basin (Newton and others, 2012; Eastoe and Rodney, 2014) indicate that water originating as high-elevation winter precipitation, and subsequently undergoing evaporation at lower elevations, generally contributes more recharge to groundwater than summer rains, except in situations where there are large summer recharge events, such as those observed in 2006, 2008, and 2013. These stable-isotope data imply that little recharge is occurring at the lower elevations in the upper Rio Hondo Basin because these areas receive a smaller amount of total precipitation, receive a smaller proportion of the annual total falling as winter precipitation, and have higher average temperatures that result in more evaporative losses. Areas at lower elevations, however, may receive some amounts of focused local recharge because of proximity to surface water and (or) prominent structural features such as the Ruidoso fault zone, located near the center of the study area (Darr and others, 2014). 


\section{Radioisotope Results}

Radioisotope samples were collected from seven groundwater wells in the upper Rio Hondo Basin between May and June 2013 (table 7). Radioisotope samples were not collected at surface-water or spring sites. Tritium levels ranged from less than the laboratory detection limit (0.08-0.09 $\mathrm{TU})$ to $3.1 \mathrm{TU}$. The highest tritium values are generally associated with sites at the higher elevations (table 7), indicating that groundwater at higher elevations generally has a larger component of young (post-1950s) recharge. A positive relation between elevation and recharge has also been identified for the nearby Sacramento Mountains by Newson and others (2012) and Eastoe and Rodney (2014). Unadjusted radiocarbon ages for groundwater collected from the seven wells ranged from about 2,400 to 9,100 years (table 7). The ${ }^{14} \mathrm{C}$ results do not have the same pattern of increasing age with decreasing elevation except for well W38, which is the highest elevation site for radioisotope analysis at $9,816 \mathrm{ft}$ and is closest to the upgradient boundary of the upper Rio Hondo Basin. The sample from this well contained the largest tritium concentration ( $3.1 \mathrm{TU}$ ) as well as containing the largest ${ }^{14} \mathrm{C}$ concentration at $73.6 \mathrm{pmC}$. These values indicate that the groundwater likely has a relatively large component of young water and a relatively young mean age, which implies proximity to an area of recharge.

Near the outlet of the upper Rio Hondo Basin, site W35 is the lowest elevation site sampled for radioisotope analysis at 5,372 $\mathrm{ft}$. The samples collected from this site contained a tritium concentration of $0.05 \mathrm{TU}$, which is less than the laboratory detection limit of $0.08 \mathrm{TU}$, and $\mathrm{a}^{14} \mathrm{C}$ concentration of $51.0 \mathrm{pmC}$. The relatively low tritium and ${ }^{14} \mathrm{C}$ concentrations of groundwater from site W35 indicate that the groundwater has a smaller component of young water (if any) and an older mean age on the far eastern side of the basin compared to the highest elevations to the west, and that other than local, focused recharge, local recharge on the far eastern side likely is minor and not widespread.

Although tritium results indicate that the proportion of young groundwater decreases away from the primary recharge areas in the higher elevation areas of the upper Rio Hondo Basin, the lack of a similar spatial pattern of ${ }^{14} \mathrm{C}$ results indicates that geochemical reactions may be affecting the ${ }^{14} \mathrm{C}$ concentrations and calculated unadjusted radiocarbon ages and (or) that there are areas where some localized recharge is occurring at lower elevations. The introduction of dead carbon from the dissolution of carbonate rocks in the Permian regional aquifer system, which likely contributes water to several of the sampled wells (W9, W26, W35, W41, and W42), can lower ${ }^{14} \mathrm{C}$ concentrations and thus artificially increase calculated groundwater ages. The relatively large variability in $\delta^{13} \mathrm{C}$ values for the seven sampled wells (-14.6 to -6.1 per mil; table 7) indicates that reactions that affect dissolved inorganic carbon are likely to be important. In addition, the seven wells are screened at various depths, some unknown, and are located at varying distances to streams and other recharge sources. For example, samples from site $\mathrm{W} 41$, at an elevation of $5,857 \mathrm{ft}$, contained a tritium concentration of $1.8 \mathrm{TU}$ and a ${ }^{14} \mathrm{C}$ concentration of $65.8 \mathrm{pM}$. These values appear more representative of a site closer to a high-elevation recharge area than to a lower-elevation area with less anticipated recharge. However, this well is located in the Rio Ruidoso alluvial valley and is screened across the young alluvium and the Permian Yeso Formation; therefore, the well is likely producing a mix of older water from the Yeso Formation and younger recharge through the alluvium from surface water originating at higher elevations. Taken as a whole, the results of the age tracers reflect the complexity of the hydrogeology of the upper Rio Hondo Basin.

The presence of a tracer used for the dating of young groundwater (tritium) in groundwater samples having unadjusted radiocarbon ages on the order of thousands of years indicates that there is a mix of younger and older groundwater within the upper Rio Hondo Basin. Other studies conducted within or in proximity to the upper Rio Hondo Basin have identified similar groundwater conditions. Matherne and others (2010) collected groundwater samples for chlorofluorocarbon (CFC) age dating in the upper Eagle Creek watershed and concluded that groundwater withdrawal wells in the North Fork of Eagle Creek were supplied by a mixture of younger and older groundwater. A mixture of younger and older groundwater was also identified in the findings of studies to the south (Newton and others, 2012; Eastoe and Rodney, 2014) and east (Hoy and Gross, 1982; Land and Huff, 2010) of the upper Rio Hondo Basin.

The mix of younger and older groundwater at varying depths and locations within the upper Rio Hondo Basin is an indication that there are multiple mechanisms of recharge, with older groundwater representing recharge that is traveling through the aquifer matrix and younger recharge likely traveling through fractures, voids, and other preferential pathways. These conditions are consistent with an area with complex geology and structural features. Although data are not robust enough to calculate relative percentages of younger and older groundwater, decreasing tritium concentrations with decreasing elevation (roughly west to east) indicate that recent recharge (post-1950s) likely is occurring primarily at higher elevations.

\section{Postfire Water Quality}

Water-quality results presented in this report are from 10 surface-water sites and 8 groundwater wells (water-quality sample not collected from W33) in the upper Rio Hondo Basin that were sampled during 2012-13 (fig. 6B; table 4). Filtered results were examined to characterize overall chemistry and were compared to historical water-quality data from streams in the upper Rio Hondo Basin collected during 1926-57 (Mourant, 1963). Surface-water-sample results were also analyzed to determine differences in unfiltered and filtered water-quality samples of streams in burned and unburned 
watersheds after the occurrence of the Little Bear Fire in June 2012. Samples were collected after postfire monsoon rain events and during periods of stable hydrologic conditions.

\section{Surface Water}

\section{General Chemistry and Historical Comparison}

Results from the analyses of the 30 surface-water samples collected in the upper Rio Hondo Basin during 2012-13 are presented in table 6. Specific conductance typically increased downstream in both the Rio Ruidoso and Rio Bonito watersheds and was similar at each sampling site during sampling rounds in July 2012, April 2013, July 2013, and November 2013 (fig. 14). Mourant (1963) observed that increased contact with carbonate rocks of the San Andres Formation resulted in increasing concentrations of dissolved solids in the downstream (eastward) direction through the upper Rio Hondo Basin. Specific conductance in the upper reaches of the Rio Bonito (site S1, fig. 14) ranged from 406 microsiemens per centimeter at 25 degrees Celsius $\left(\mu \mathrm{S} / \mathrm{cm}\right.$ at $25^{\circ} \mathrm{C}$ ) to $627 \mu \mathrm{S} / \mathrm{cm}$ at $25^{\circ} \mathrm{C}$ (table 6) with a median value of $495 \mu \mathrm{S} / \mathrm{cm}$ at $25^{\circ} \mathrm{C}$. Specific conductance in the Rio Bonito increased downstream, with maximum values observed just above the confluence of the Rio Bonito and the Rio Ruidoso (site S4) (figs. $6 B$ and 14). Specific conductance at site $\mathrm{S} 4$ ranged from $1,120 \mu \mathrm{S} / \mathrm{cm}$ at $25^{\circ} \mathrm{C}$ (July 2012) to $1,910 \mu \mathrm{S} / \mathrm{cm}$ at $25^{\circ} \mathrm{C}$ (July 2013) (table 6) with a median value of $1,430 \mu \mathrm{S} / \mathrm{cm}$ at $25^{\circ} \mathrm{C}$. Specific conductance in the Rio Ruidoso also generally increased downstream, with maximum values observed at sites S7 and S8 (figs. $6 B$ and 14). The median value of specific conductance was $1,640 \mu \mathrm{S} / \mathrm{cm}$ at $25{ }^{\circ} \mathrm{C}$ at site S7 and $1,870 \mu \mathrm{S} / \mathrm{cm}$ at $25^{\circ} \mathrm{C}$ at site S8. Specific conductance measured in the Rio Bonito and Rio Ruidoso as part of this study was similar to historical specific conductance data collected during 1955-57 (fig. 14) that had a median value of $1,010 \mu \mathrm{S} / \mathrm{cm}$ at $25^{\circ} \mathrm{C}$ in the Rio Bonito and $1,395 \mu \mathrm{S} / \mathrm{cm}$ at $25^{\circ} \mathrm{C}$ in the Rio Ruidoso (Mourant, 1963).

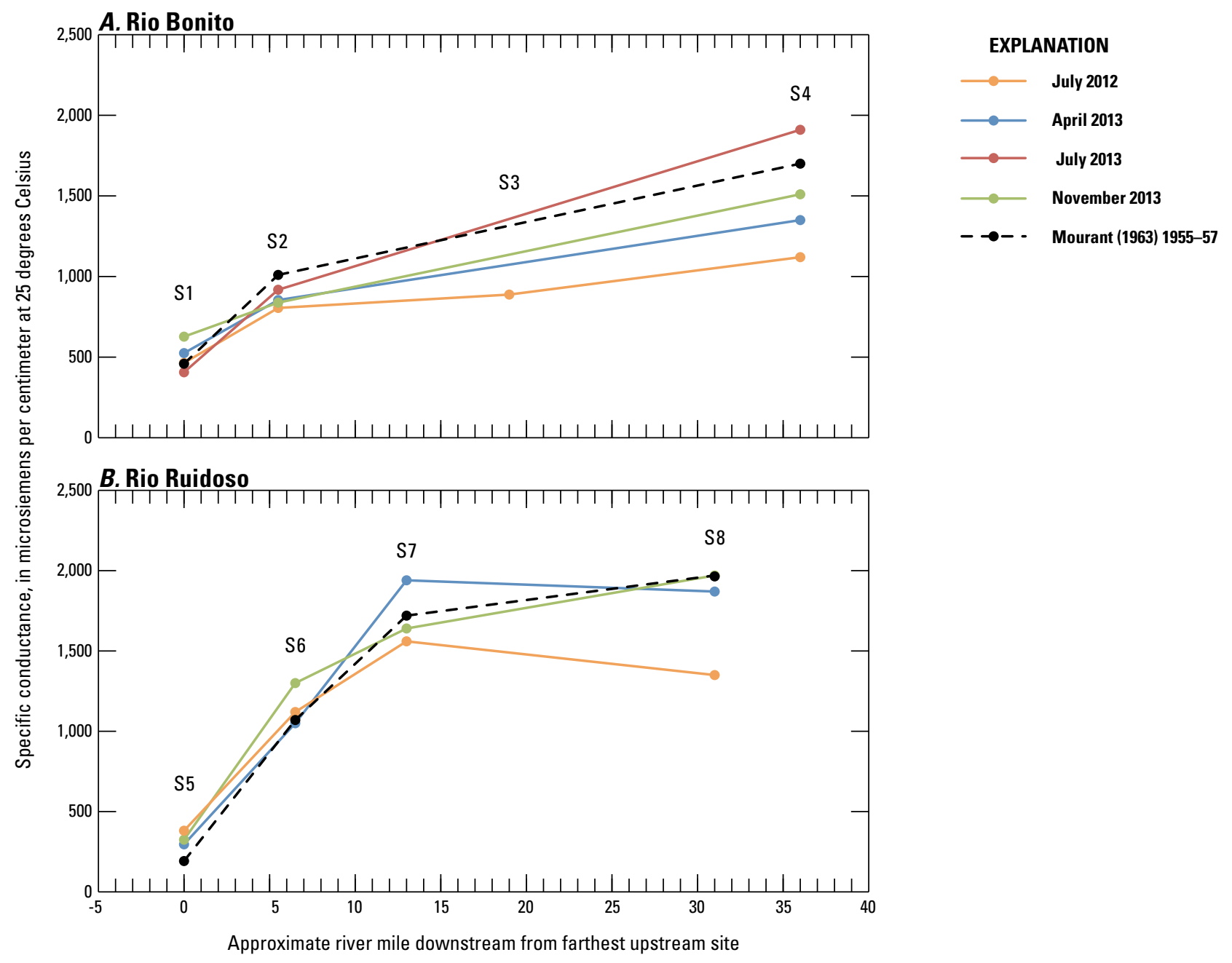

Figure 14. Specific conductance according to approximate river mile in the $A$, Rio Ruidoso and $B$, Rio Bonito, upper Rio Hondo Basin, Lincoln County, New Mexico. 
Other field measurements varied from site to site but did not show obvious spatial or temporal trends. Dissolvedoxygen concentrations among all surface-water samples and sites ranged from $4.4 \mathrm{mg} / \mathrm{L}$ to $14.9 \mathrm{mg} / \mathrm{L}$ (table 6) with a median value of $7.85 \mathrm{mg} / \mathrm{L}$. It is presumed that the minimum dissolved-oxygen concentration of $4.4 \mathrm{mg} / \mathrm{L}$, observed at site $\mathrm{S} 2$, was influenced by the presence of fire debris during elevated streamflow conditions at the time of sampling. Water temperature ranged from $6.0^{\circ} \mathrm{C}$ to $33.6^{\circ} \mathrm{C}$ with a median value of $16.3^{\circ} \mathrm{C}$. The range of temperatures can be primarily attributed to the time of day and season that the sample was collected. Values of $\mathrm{pH}$ ranged from 7.2 to 8.9 (table 6) with a median value of 7.9 .
Major-ion concentrations varied from site to site in the upper Rio Hondo Basin. A trilinear diagram that illustrates the relative proportion of major cations and anions in milliequivalents per liter (fig. 15) indicates that surface water can be characterized as calcium-type, with variability in relative major-anion concentration (bicarbonate, sulfate, and chloride) (Piper, 1944). The Rio Bonito and Rio Ruidoso watershed samples exhibit similar variability in relative concentrations of major anions and cations, except for chloride. Median chloride concentrations were higher in the Rio Ruidoso watershed $(57.6 \mathrm{mg} / \mathrm{L})$ than in the Rio Bonito watershed (32.7 mg/L) (table 8). Water type also varied with elevation in the upper Rio Hondo Basin with regard to

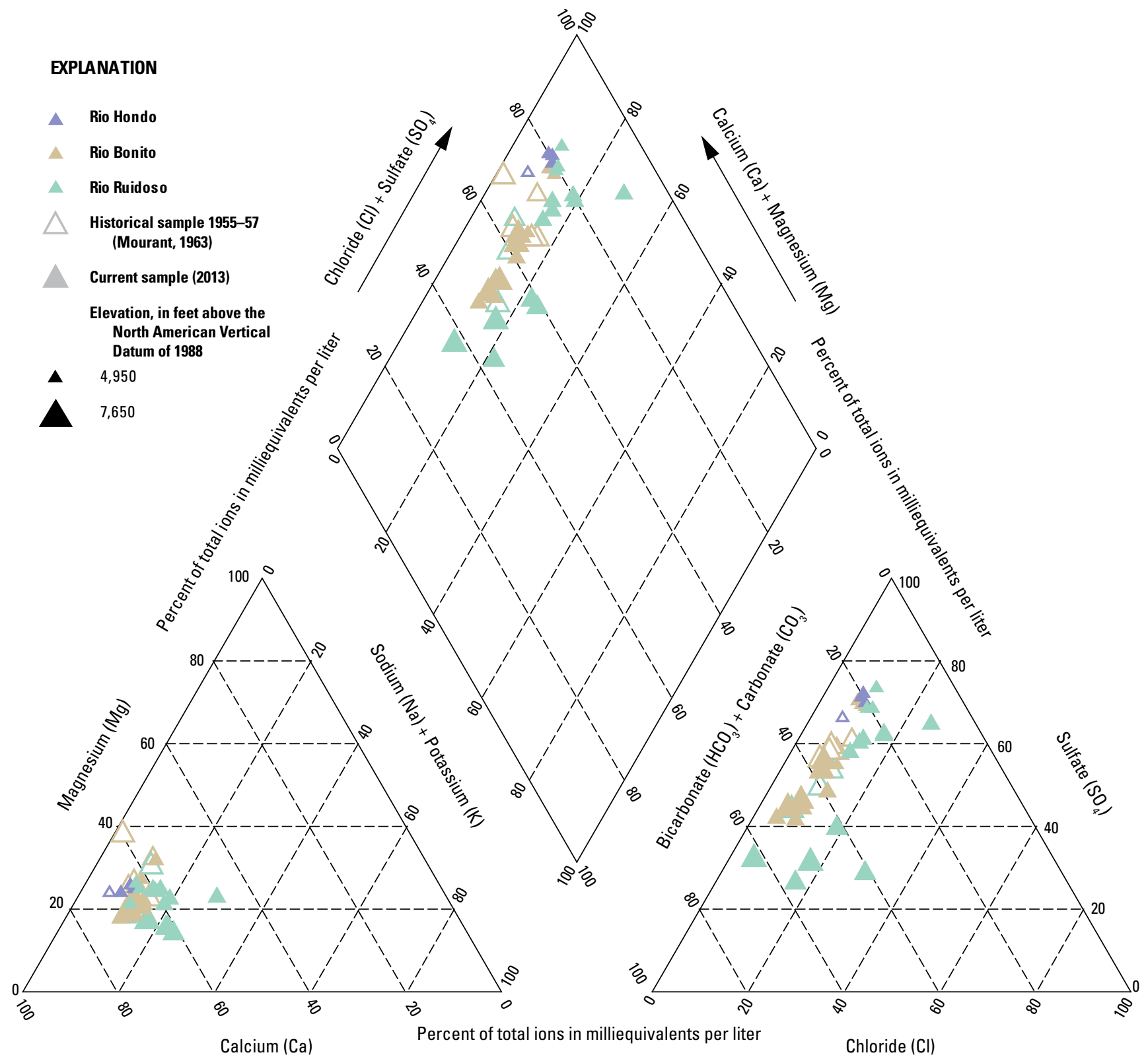

Figure 15. Hydrochemical-facies classification of major-ion chemistry of surface water in the upper Rio Hondo Basin, Lincoln County, New Mexico, sampled from 1955 to 1957 and in 2012 and 2013. 
major anions. Samples generally evolved from bicarbonate dominant at higher elevations to sulfate dominant at lower elevations (fig. 15). Increasing sulfate concentrations can be attributed to the greater influence of gypsum or anhydrite found in the Yeso Formation as streams flow eastward through the upper Rio Hondo Basin in the Permian regional aquifer system (Hall, 1964). Surface-water samples appear to have similar overall major-ion chemical characteristics when compared to historical water-quality data collected from 1955 to 1957 (Mourant, 1963), when samples were also collected during drought conditions. In the Sacramento Mountains, groundwater from the primary water-bearing formations of the Yeso and San Andres Formations has been previously identified as calcium sulfate to calcium bicarbonate-sulfate type (Hall, 1964; Newton and others, 2012).

Concentrations of selected nutrients analyzed in the filtered surface-water samples varied between sites. For example, median nitrate plus nitrite concentrations in the Rio Ruidoso watershed were greater than those in the Rio Bonito watershed $(0.49 \mathrm{mg} / \mathrm{L}$ and $0.08 \mathrm{mg} / \mathrm{L}$, respectively) (table 8 ), but the highest concentrations (as much as $3.41 \mathrm{mg} / \mathrm{L}$ ) (table 6) were observed in the Rio Bonito watershed at site $\mathrm{S} 1$, located above Bonito Lake within the perimeter of the Little Bear Fire (fig. 6B). Median nitrite concentrations in the Rio Ruidoso watershed and the Rio Bonito watershed were low $(0.003 \mathrm{mg} / \mathrm{L}$ and 0.010 , respectively) (table 8$)$. Median phosphorus concentrations in the Rio Bonito watershed were greater than those in the Rio Ruidoso watershed $(0.041 \mathrm{mg} / \mathrm{L}$ and $0.016 \mathrm{mg} / \mathrm{L}$, respectively) (table 8), but it is suspected that flushing of nutrients during monsoon rain events after the Little Bear Fire caused this difference. Influence of the Little Bear Fire on filtered samples is further discussed in the "Postfire Water Quality" section.

Similar to nutrient concentrations, selected traceelement concentrations in the filtered surface-water samples varied between sites. The trace element with the highest concentrations in both the Rio Ruidoso and Rio Bonito watersheds was manganese, with median concentrations of $30.7 \mu \mathrm{g} / \mathrm{L}$ and $32.8 \mu \mathrm{g} / \mathrm{L}$, respectively (table 8 ). Concentrations of aluminum, iron, arsenic, and uranium exhibited variability but a consistent spatial or temporal pattern was not identified. Generally, median concentrations of these constituents were similar in the Rio Ruidoso and the Rio Bonito (table 8). Concentrations of manganese exceeded the U.S. Environmental Protection Agency (EPA) National Secondary Drinking Water Regulation (NSDWR) of $50 \mu \mathrm{g} / \mathrm{L}$ (table 9) in 11 filtered samples collected during various times of the year from sites located in burned and unburned watersheds. Results show that dissolved aluminum exceeded the EPA NSDWR of $200 \mu \mathrm{g} / \mathrm{L}$ (table 9) by an order of magnitude in a single sample collected from the Rio Bonito (site S4) (table 6), approximately 1 month after the occurrence of the Little Bear Fire. The EPA NSDWRs are nonenforced standards that are established as guidelines to assist public water systems in managing their drinking water for aesthetic considerations, such as taste, color, and odor (U.S. Environmental Protection Agency, 2014).

Table 8. Median concentrations of selected water-quality constituents from filtered samples collected in the upper Rio Hondo Basin, Lincoln County, New Mexico.

$\left[\mathrm{mg} / \mathrm{L}\right.$, milligrams per liter; $\mu \mathrm{S} / \mathrm{cm}$ at $25^{\circ} \mathrm{C}$, microsiemens per centimeter at 25 degrees Celsius; NMED, New Mexico Environment Department; USGS, U.S. Geological Survey; N, nitrogen; P, phosphorus; $\mu \mathrm{g} / \mathrm{L}$, micrograms per liter; --, not measured]

\begin{tabular}{|c|c|c|c|c|c|c|c|c|c|c|c|c|}
\hline $\begin{array}{l}\text { Watershed } \\
\text { name }\end{array}$ & $\begin{array}{c}\text { Col- } \\
\text { lecting } \\
\text { agency }\end{array}$ & $\begin{array}{c}\text { Year } \\
\text { collected }\end{array}$ & $\begin{array}{c}\text { Dis- } \\
\text { solved } \\
\text { oxygen } \\
\text { (mg/L) }\end{array}$ & $\begin{array}{c}\text { pH, field } \\
\begin{array}{c}\text { (standard } \\
\text { units) }\end{array} \\
\end{array}$ & $\begin{array}{l}\text { Specific } \\
\text { conduc- } \\
\text { tance, } \\
\text { field } \\
(\mu \mathrm{S} / \mathrm{cm} \\
\left.\text { at } 25^{\circ} \mathrm{C}\right) \\
\end{array}$ & $\begin{array}{c}\text { Water } \\
\text { temper- } \\
\text { ature } \\
\text { (degrees } \\
\text { Celsius) }\end{array}$ & $\begin{array}{c}\text { Cal- } \\
\text { cium, } \\
\text { filtered } \\
(\mathrm{mg} / \mathrm{L})\end{array}$ & $\begin{array}{c}\text { Mag- } \\
\text { nesium, } \\
\text { filtered } \\
\text { (mg/L) }\end{array}$ & $\begin{array}{l}\text { Potas- } \\
\text { sium, } \\
\text { filtered } \\
\text { (mg/L) }\end{array}$ & $\begin{array}{c}\text { Sodium, } \\
\text { filtered } \\
\text { (mg/L) }\end{array}$ & $\begin{array}{l}\text { Alkalin- } \\
\text { ity, lab } \\
\text { (mg/L as } \\
\text { calcium } \\
\text { carbon- } \\
\text { ate) }\end{array}$ & $\begin{array}{c}\text { Chloride, } \\
\text { filtered } \\
\text { (mg/L) }\end{array}$ \\
\hline Rio Bonito $^{1}$ & NMED & 2003 & 8.2 & 7.6 & 823 & 13.7 & 117 & 24.6 & 4.1 & 44.1 & 148 & 59.0 \\
\hline $\begin{array}{l}\text { Watershed } \\
\text { name }\end{array}$ & $\begin{array}{c}\text { Col- } \\
\text { lecting } \\
\text { agency }\end{array}$ & $\begin{array}{c}\text { Year } \\
\text { collected }\end{array}$ & $\begin{array}{c}\text { Sulfate, } \\
\text { filtered } \\
\text { (mg/L) }\end{array}$ & $\begin{array}{c}\text { Nitrate + } \\
\text { nitrite, } \\
\text { filtered } \\
\text { (mg/L as } \mathrm{N} \text { ) }\end{array}$ & $\begin{array}{r}\mathrm{Nit} \\
\text { filt } \\
\text { (mg/l }\end{array}$ & $\begin{array}{l}\text { trite, } \\
\text { tered } \\
\text { L as } N \text { ) }\end{array}$ & $\begin{array}{l}\text { Phos- } \\
\text { phorus, } \\
\text { filtered } \\
\text { mg/L as P) }\end{array}$ & $\begin{array}{c}\text { Alumi- } \\
\text { num, } \\
\text { filtered } \\
(\mu \mathrm{g} / \mathrm{L})\end{array}$ & $\begin{array}{c}\text { Iron, } \\
\text { filtered } \\
\text { ( } \mu \mathrm{g} / \mathrm{L})\end{array}$ & $\begin{array}{c}\text { Man- } \\
\text { ganese, } \\
\text { filtered } \\
(\mu \mathrm{g} / \mathrm{L})\end{array}$ & $\begin{array}{c}\text { Arsenic, } \\
\text { filtered } \\
(\mu \mathrm{g} / \mathrm{L})\end{array}$ & $\begin{array}{c}\text { Uranium } \\
\text { (natural), } \\
\text { filtered } \\
(\mu \mathrm{g} / \mathrm{L})\end{array}$ \\
\hline Rio Ruidoso & USGS & $2012-13$ & 390 & 0.49 & & 003 & 0.016 & 8.5 & 13.0 & 30.7 & 0.5 & 1.3 \\
\hline
\end{tabular}

${ }^{1}$ Collected from different sites than those used in this study (New Mexico Environment Department Surface Water Quality Bureau, 2003). 
Table 9. Number of surface-water and groundwater quality samples exceeding U.S. Environmental Protection Agency National Secondary Drinking Water Regulation standards in the upper Rio Hondo Basin, Lincoln County, New Mexico.

[NSDWR, National Secondary Drinking Water Regulation; mg/L, milligrams per liter; --, no exceedances; $\mu \mathrm{g} / \mathrm{L}$, micrograms per liter]

\begin{tabular}{lccc}
\hline \multicolumn{1}{c}{ Contaminant } & NSDWR & $\begin{array}{c}\text { Number of } \\
\text { surface-water } \\
\text { exceedances }\end{array}$ & $\begin{array}{c}\text { Number of } \\
\text { groundwater } \\
\text { exceedances }^{2}\end{array}$ \\
\hline Chloride $(\mathrm{mg} / \mathrm{L})$ & 250 & -- & 2 \\
Sulfate $(\mathrm{mg} / \mathrm{L})$ & 250 & 16 & 7 \\
Aluminum $(\mu \mathrm{g} / \mathrm{L})$ & 200 & 1 & -- \\
Manganese $(\mu \mathrm{g} / \mathrm{L})$ & 50 & 11 & 2 \\
\hline
\end{tabular}

${ }^{1}$ Thirty total surface-water-quality samples.

${ }^{2}$ Eight total groundwater-quality samples.

\section{Postfire Water Quality}

Wildfires, when coupled with precipitation events, can lead to substantial sediment loading in streams (Moody and Martin, 2001), leaving the burned watersheds of the upper Rio Hondo Basin at risk of substantial postfire debris flows and flash floods (Tillery and Matherne, 2013). Wildfires can also have substantial effects on downstream water quality (Neary and others, 2008; Smith and others, 2011; Stevens, 2013). This section of the report compares water quality of streams in burned (Eagle Creek and Rio Bonito) and unburned (Rio Ruidoso) watersheds after the Little Bear Fire of June 2012 in samples collected after postfire monsoon rain events and during periods of stable hydrologic conditions. Field measurements and water-quality data collected in 2012-13 from burned and unburned watersheds are shown in table 6 .

After the occurrence of the Little Bear Fire (June 2012), surface-water samples were collected after postfire monsoon rain events (July 2012 and July 2013) and during periods of stable hydrologic conditions (April 2013 and November 2013) in burned (Rio Bonito, which includes Eagle Creek) and unburned (Rio Ruidoso) watersheds (fig. 6B). Sampling sites in burned watersheds included one site on Eagle Creek (site S9) and four sites on the Rio Bonito (sites S1, S2, S3, and S4) (fig. 6B; table 4). Site S3 was sampled only in July 2012 because of stagnant, nonflowing conditions during the rest of the sampling events. Dry conditions prevented the sampling of site S9 in April 2013 and November 2013. Sampling sites in the unburned watershed included three sites on the Rio Ruidoso (sites S5, S6, and S7) (fig. 6B; table 4). Sites in the unburned watershed were sampled three times-July 2012, April 2013, and November 2013.

Large sediment loads after postfire monsoon rain events in July 2012 and July 2013 occurred in the Rio Bonito watershed (burned), with streams exhibiting maximum turbidity values of 4,090 nephelometric turbidity ratio units (NTRU) (site S4) in July 2012 and 400 NTRU (site S2) in July 2013 (table 6). The median turbidity value in the Rio Bonito watershed in July 2012 was 1,505 NTRU compared to streams in the Rio Ruidoso watershed (unburned) exhibiting a median turbidity value of 59 NTRU (table 6 ) for the same time period. Turbidity values in the Rio Bonito watershed were greatly diminished during stable hydrologic conditions less than one year after the Little Bear Fire in April 2013 ( $<2$ NTRU; table 6); but increased again in July 2013 because of increased monsoon precipitation. This reflects a pattern related to flushing and transport occurring primarily during high flow.

Despite substantial sediment loading during postfire monsoon rain events, specific conductance and most major ions did not exhibit major increases in July 2012 and July 2013 relative to stable hydrologic conditions in April 2013 and November 2013 in the Rio Bonito watershed (table 6). Potassium was the only major ion that did not follow this pattern, as filtered concentrations in the Rio Bonito watershed ranged from 6.75 to $18.0 \mathrm{mg} / \mathrm{L}$ in July 2012 during high streamflow following the first postfire monsoon rain event and decreased in subsequent sampling events (fig. 16; table 6). The median potassium concentration was $2.0 \mathrm{mg} / \mathrm{L}$ for all other filtered samples collected in the Rio Bonito watershed and $3.1 \mathrm{mg} / \mathrm{L}$ for all filtered samples collected in the unburned Rio Ruidoso watershed. Samples collected during the first postfire monsoon rain event in July 2012 generally had the lowest specific conductance values of all four sampling events on the Rio Bonito (fig. 14A) and at the downstream stations on the Rio Ruidoso (S7 and S8) (fig. 14B). In general, major ions exhibited some variability through time but no obvious trend of increasing concentrations over time in samples collected after the occurrence of the Little Bear Fire was observed.

The first postfire monsoon rain event in July 2012 generally produced the highest measured concentrations of potassium, selected nutrients, and total organic carbon in unfiltered samples collected in the burned watersheds of the Rio Bonito (S1, S2, S3, and S4) and Eagle Creek (S9) relative to later samples collected in burned watersheds and all samples collected in the unburned watershed of the Rio Ruidoso (S5, S6, and S7) (fig. 16). Maximum concentrations of the unfiltered samples of potassium $(26.2 \mathrm{mg} / \mathrm{L})$, ammonia plus organic nitrogen (total as N) $(27 \mathrm{mg} / \mathrm{L}$ ), phosphorus $(5.95 \mathrm{mg} / \mathrm{L})$, and total organic carbon $(325 \mathrm{mg} / \mathrm{L})$ in the Rio Bonito observed in July 2012 exceeded concentrations of later samples collected in the Rio Bonito and all samples collected in the unburned watershed of the Rio Ruidoso. Maximum concentrations of potassium $(10.8 \mathrm{mg} / \mathrm{L})$, ammonia plus organic nitrogen (total as N) $(3.6 \mathrm{mg} / \mathrm{L})$, and total organic carbon $(38.9 \mathrm{mg} / \mathrm{L})$ in Eagle Creek observed in July 2012 exceeded concentrations of the later sample collected in Eagle Creek and all samples collected in the unburned watershed of the Rio Ruidoso. 

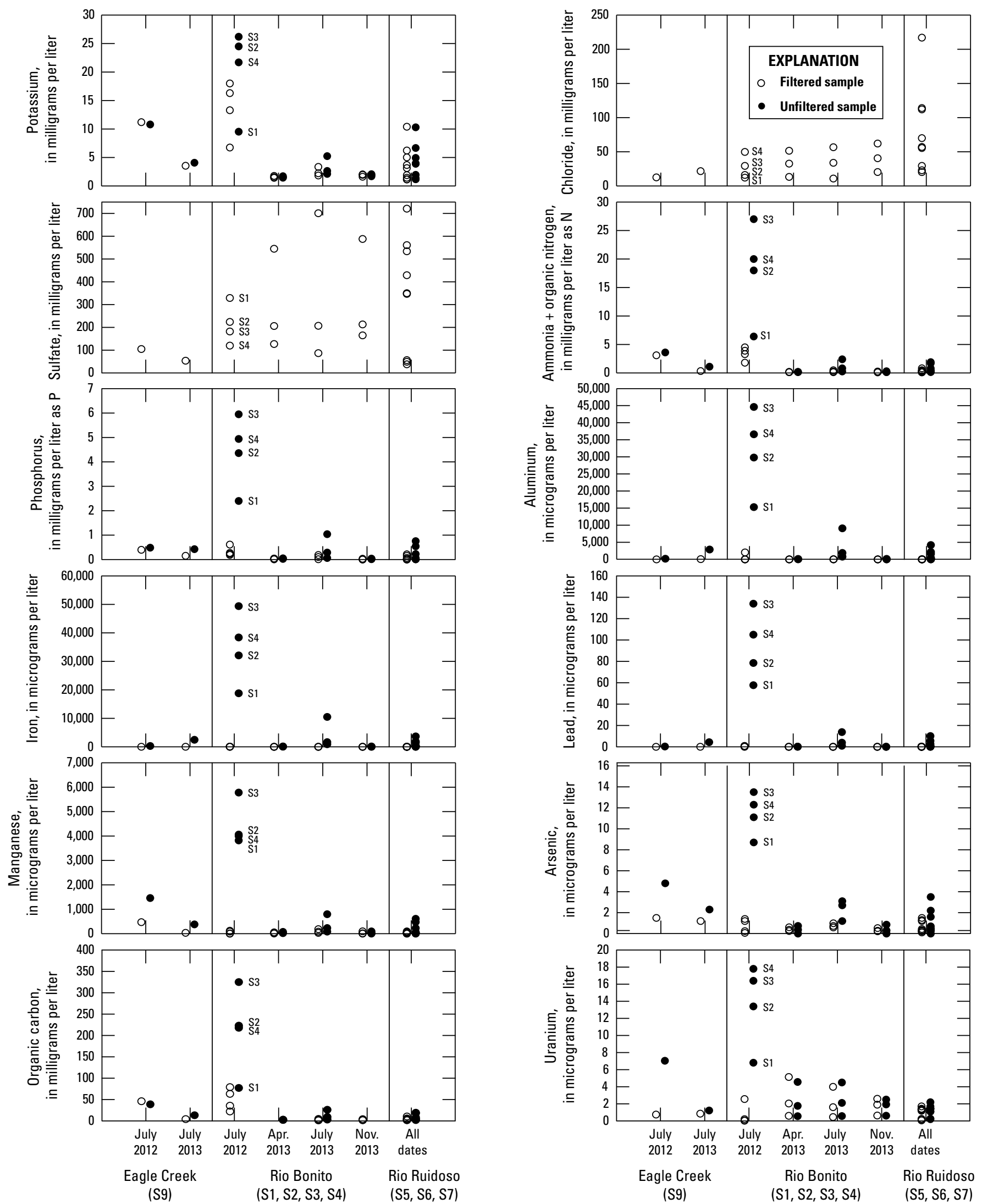

Figure 16. Concentrations of selected water-quality constituents at Eagle Creek, Rio Bonito, and Rio Ruidoso, 2012-13, upper Rio Hondo Basin, Lincoln County, New Mexico. 
High concentrations of selected trace elements in unfiltered samples also were observed after the first postfire monsoon rain event in July 2012 (fig. 16). Maximum concentrations of aluminum $(44,600 \mu \mathrm{g} / \mathrm{L} ; \mathrm{S} 3)$, iron $(49,400 \mu \mathrm{g} / \mathrm{L} ; \mathrm{S} 3)$, lead $(134 \mu \mathrm{g} / \mathrm{L} ; \mathrm{S} 3)$, manganese $(5,780 \mu \mathrm{g} / \mathrm{L} ; \mathrm{S} 3)$, arsenic $(13.5 \mu \mathrm{g} / \mathrm{L} ; \mathrm{S} 3)$, and uranium $(17.8 \mu \mathrm{g} / \mathrm{L} ; \mathrm{S} 4)$ in the Rio Bonito observed in July 2012 exceeded concentrations of later samples collected in the Rio Bonito, samples collected during July 2012 in Eagle Creek, and all samples collected in the unburned watershed of the Rio Ruidoso (table 6). Maximum concentrations of manganese $(1,460 \mu \mathrm{g} / \mathrm{L})$, arsenic $(4.8 \mu \mathrm{g} / \mathrm{L})$, and uranium $(7.0 \mu \mathrm{g} / \mathrm{L})$ in Eagle Creek observed in July 2012 exceeded concentrations of the later sample collected in Eagle Creek and all samples collected in the unburned watershed of the Rio Ruidoso.

Elevated concentrations of several other trace elements also were observed in unfiltered samples collected in the Rio Bonito in July 2012 relative to subsequent sampling events. Maximum concentrations were observed at site $\mathrm{S} 3$ and include cadmium $(2.33 \mu \mathrm{g} / \mathrm{L})$, copper $(64.4 \mu \mathrm{g} / \mathrm{L})$, and zinc $(241 \mu \mathrm{g} / \mathrm{L})$ (table 6).

Concentrations of selected constituents in unfiltered samples collected from the Rio Bonito in July 2012 exhibited a consistent spatial pattern (fig. 16), with the lowest concentrations observed at site $\mathrm{S} 1$ and the highest concentrations typically observed at site $\mathrm{S} 3$. Site $\mathrm{S} 1$ is located above Bonito Lake and sites S2, S3, and S4 are located below Bonito Lake (fig. 6B; table 4). Postfire monsoon rain events occurring on burned drainages delivered high amounts of sediment and ash into Bonito Lake during the summer of 2012 (Snyder and others, 2012). Substantial dredging and pumping has occurred in Bonito Lake since 2012 (Stallings, 2012), which has resulted in sediment and ash flows downstream from the lake that have likely contributed to the spatial pattern of degraded water quality.

Although diminished compared to concentrations observed in samples collected after the first postfire monsoon rain event in July 2012, some sites in the burned watersheds (Rio Bonito and Eagle Creek) exhibited higher concentrations of selected constituents in unfiltered samples collected after precipitation events approximately 1 year after the Little Bear Fire in July 2013 when compared to concentrations observed during stable hydrologic conditions (fig. 16; table 6). It is important to note that samples collected in July 2013 were collected prior to the peak streamflow observed in summer 2013 (fig. 7), and thus may not reflect the maximum concentrations of fire-related constituents that occurred during other monsoon rain events.

Concentrations of constituents shown in figure 16 in the Rio Bonito were generally lower during stable hydrologic conditions in April 2013 and November 2013, in filtered and unfiltered samples, relative to samples collected in July 2012 and July 2013 after postfire monsoon rain events. Concentrations of fire-related constituents in samples collected in the Rio Bonito in April 2013 and November 2013 were mostly less than or equal to concentrations during all sampling periods in the unburned watershed (Rio Ruidoso). Concentrations of selected major ions and fire-related constituents from all filtered samples in the Rio Bonito in 2013 were generally similar to a limited set of historical waterquality samples collected in the Rio Bonito as part of a New Mexico State survey of the Rio Hondo watershed completed in 2003 (New Mexico Environment Department Surface Water Quality Bureau, 2003), with certain trace elements exhibiting slightly higher values in 2013 than 2003 (aluminum, iron, manganese, and arsenic) (table 8). Despite no obvious indications of major changes to water quality in the Rio Bonito after the Little Bear Fire during stable hydrologic conditions based on samples collected at a limited frequency, it is evident that monsoon rain events have affected water quality by delivering larger sediment loads and fire-related constituents into streams in the upper Rio Hondo Basin.

\section{General Groundwater Chemistry and Historical Comparison}

Results from the analyses of the eight groundwater samples collected from wells in the upper Rio Hondo Basin during May and June 2013 are presented in table 6. Groundwater was slightly acidic to slightly alkaline $(\mathrm{pH}$ values ranged from 6.4 to 7.6 with a median value of 6.6) with field alkalinity as calcium carbonate $\left(\mathrm{CaCO}_{3}\right)$ ranging from 77 to $317 \mathrm{mg} / \mathrm{L}$ with a median value of $176 \mathrm{mg} / \mathrm{L}$. Specific conductance values ranged from $771 \mu \mathrm{S} / \mathrm{cm}$ at $25^{\circ} \mathrm{C}$ (well W38) to $2,760 \mu \mathrm{S} / \mathrm{cm}$ at $25^{\circ} \mathrm{C}$ (well W26); the median specific conductance was $1,680 \mu \mathrm{S} / \mathrm{cm}$ at $25^{\circ} \mathrm{C}$. Median specific conductance in 104 wells sampled from 1939-60 was $1,285 \mu \mathrm{S} / \mathrm{cm}$ at $25^{\circ} \mathrm{C}$ and showed an increasing spatial trend moving eastward through the upper Rio Hondo Basin (Mourant, 1963).

The trilinear diagram (fig. 17) indicates most historical and 2013 groundwater samples exhibit similar major-ion chemical characteristics and can be characterized as calciumtype, with variability in relative major-anion concentration (bicarbonate, sulfate, and chloride) (Piper, 1944). In the Sacramento Mountains, the presence of calcium and bicarbonate can be attributed primarily to the dissolution of limestone or the presence of calcite, with increasing sulfate concentrations typically resulting from dissolution of gypsum or anhydrite that can be found in the Yeso Formation (Hall, 1964; Newton and others, 2012). Samples collected from groundwater wells W38, W39, and W40 plot slightly separate from the rest of the groundwater samples collected in 2013, with higher proportions of bicarbonate, relative to sulfate. The remaining wells sampled in 2013 (W9, W26, W35, W41, and W42) are completed in the Permian regional aquifer system, which is composed primarily of limestone, dolomite, and sandstone (Darr and others, 2014), and exhibit relatively higher proportions of sulfate. Wells 38 and 40 are completed 


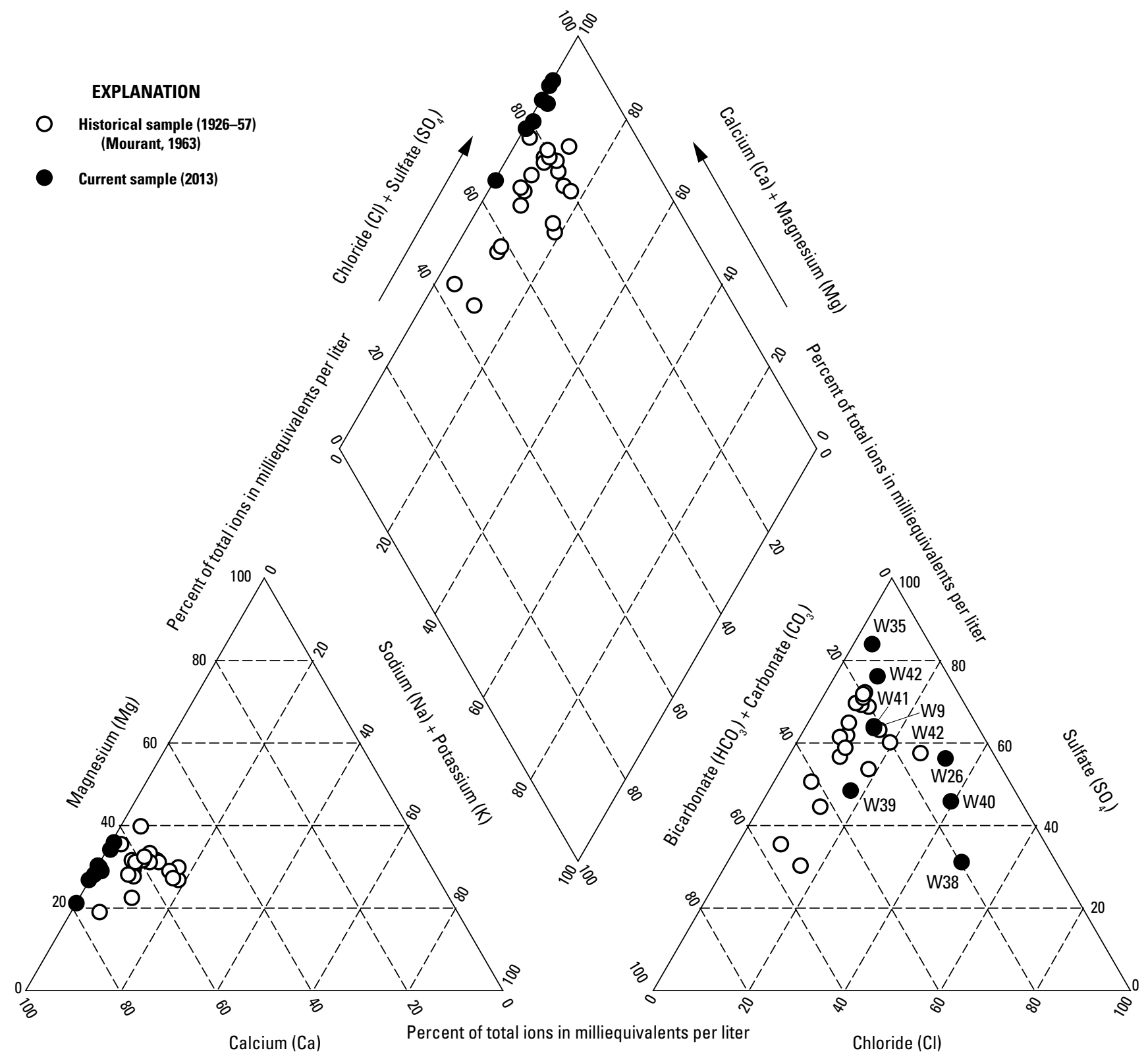

Figure 17. Hydrochemical-facies classification of major-ion chemistry of groundwater in the upper Rio Hondo Basin, Lincoln County, New Mexico, sampled from 1926 to 1957 and 2013.

in Tertiary volcanics and have higher proportions of chloride; well 39 is completed in Cretaceous shales and sandstones. Groundwater samples appear to have similar major-ion chemical characteristics when compared to historical waterquality data from Mourant (1963), but the samples are not directly comparable because they are from different sets of wells (fig. 17).

Selected nutrient and trace-element concentrations exhibited variability between groundwater sites. Concentrations of nitrate, nitrite, and total phosphorus measured in the groundwater samples varied only slightly between samples (table 6). For example, nitrate plus nitrite concentrations for all eight groundwater samples ranged from less than $0.01 \mathrm{mg} / \mathrm{L}$ to $1.06 \mathrm{mg} / \mathrm{L}$ (W41) with 3 of the 8 samples exhibiting values less than the LRL of $0.01 \mathrm{mg} / \mathrm{L}$ (W9, W38, and W40). The concentrations of filtered phosphorus were less than the LRL of $0.003 \mathrm{mg} / \mathrm{L}$ for all groundwater samples except those collected at W9 $(0.005 \mathrm{mg} / \mathrm{L})$ and W39 $(0.034 \mathrm{mg} / \mathrm{L})$. Concentrations of manganese exceeded the EPA NSDWR of $50 \mu \mathrm{g} / \mathrm{L}$ (table 9) in two filtered groundwater samples (W38 and W40). 


\section{Water Quality and Water Resources: Implications of Changes in Climate and Water Use}

Changes in climate (including drought, the occurrence of wildfires, and shifts in the variability and distribution of precipitation) and increased groundwater and surfacewater use are likely to affect the availability of water in the upper Rio Hondo Basin. Climate researchers have predicted increasing variability of precipitation and streamflow distributions in the western United States, with more frequent extreme events such as floods and droughts (Karl and Knight, 1998; Garfin and others, 2013). Changing climate conditions are also expected to alter the timing and magnitude of snowmelt (Dettinger, 2005, Hall and others, 2006, Knowles and others, 2006; Stewart, 2009; Clow, 2010; Garfin and others, 2013) and result in an increase in the frequency and intensity of wildfire occurrence in the western United States (Westerling and others, 2006; Allen and others, 2010). This section of the report discusses the likely implications of continued drought and increasing water use on water quality and water resources of the upper Rio Hondo Basin.

Wildfires, when coupled with precipitation events, can lead to substantial flash flooding and sediment loading in streams (Moody and Martin, 2001) and can affect downstream water quality (Neary and others, 2008; Smith and others, 2011; Writer and Murphy, 2012). Degraded water quality as a result of wildfires may have negative effects on public water supply and may limit the success of aquatic life. In this study, selected fire-related constituents were elevated above background levels 1 year after the occurrence of the Little Bear Fire, particularly during monsoon rain events. The effects of fire are typically observed to persist in water-quality samples from 1 to 5 years in burned watersheds (Ranalli, 2004; Smith and others, 2011). How long recovery of the upper Rio Hondo Basin will take is not known. In addition, because the effects of fire on water quality appear to affect surface-water resources more than groundwater, it can be assumed that additional fires in the study area may cause increased reliance on water from wells and put further consumptive strain on groundwater resources if surface-water resources become unsuitable for municipal use.

Predicted reductions in winter precipitation, changes in form of precipitation, and earlier seasonal melting of snowpack may have an adverse effect on the amount of groundwater recharge that occurs in the upper Rio Hondo Basin, given the predominance of winter precipitation recharge as indicated by the stable isotope results. Smaller snowpacks will result in less water available for recharge, and earlier melting because of higher temperatures will result in more of the snowmelt being potentially lost to runoff instead of infiltration into the subsurface. Additionally, reductions in total precipitation for the region will not be a one-to-one relation with reductions in surface water and groundwater supplies in the upper Rio Hondo Basin. For example, Darr and others (2014) concluded that a 20-percent decrease in precipitation in the basin would result in a 50-percent decrease in streamflow, whereas a 10-percent decrease in precipitation would lower total streamflow by 40 percent.

Increases in extreme summer storm events may induce recharge, but these events may be less widespread than frontal storms that bring winter precipitation (Darr and others, 2014), and runoff from summer storms will be more rapid, and provide less recharge, than a melting snowpack. In the nearby southern Sacramento Mountains, years with abundant summer precipitation appear to result in localized and shortlived increases in groundwater levels, but these increases are mostly seen in high-elevation aquifers (Eastoe and Rodney, 2014). The higher elevations in the upper Rio Hondo Basin are the focus of municipal groundwater demand and pumping and are also the areas where the majority of recent recharge likely is occurring. Lower-elevation areas in the study area may become targets for additional groundwater development to supply a growing population, but these areas are likely not receiving as much direct substantial recharge as the highelevation areas.

Given the mix of younger and older groundwater found throughout the upper Rio Hondo Basin, areas with a larger component of younger water may be more susceptible to yearly or multiyear variations. Parts of the study area with a large component of older groundwater may be supplied by water that was recharged thousands of years ago when the climate may have been wetter and therefore are not being replenished as readily as they once were.

Reductions in groundwater storage will likely result in decreased streamflow in gaining reaches, and reductions in streamflow will likely reduce groundwater recharge along losing reaches. Matherne and others (2010) noted that stable isotopic results in upper Eagle Creek indicated a connection between shallow groundwater and streamflow, and groundwater pumping was linked to increases in the number of no-flow days on Eagle Creek. The combination of drought conditions, decreased streamflows, and increased pumping has also been linked to decreased groundwater discharge at Hale Spring (SP3, fig. 6B), the majority source of municipal supply to the City of Ruidoso Downs, with rates of spring flow decline related to nearby groundwater withdrawal rates (Riesterer and others, 2006). Stable isotope values from Riesterer and others (2006) also indicate a hydrualic connection between surface water and groundwater.

Barlow and Leake (2012) discuss the interrelation between surface water and groundwater, focusing on how groundwater pumping not only decreases the amount of base flow available to surface water but may in some instances draws water away from the surface-water system. Decreases in surface-water supplies because of persistent drought conditions and reductions in the quality of water because of the effects of wildfire could lead to a larger reliance on groundwater reserves in the upper Rio Hondo Basin. Decreasing water levels because of increasing groundwater withdrawal could reduce base-flow contribution to the Rio Bonito and Rio Ruidoso, perpetuating a cycle that would be 
detrimental to water resources as a whole within the study area. From a water-management perspective, past practices for planning and managing water resources may not be applicable to the changing conditions the region may be facing. Milly and others (2008) state that for planning purposes, the past can no longer be considered a reasonable representation of what the future holds. Well organized and scientifically-supported regional water-resources management will be necessary for dealing with a scenario of increases in demand coupled with decreases in supply in the upper Rio Hondo Basin.

\section{Summary}

Stakeholders and water-resource managers in Lincoln County, New Mexico, have had long-standing concerns over the effects of population growth and groundwater withdrawals. These concerns have been exacerbated by recent drought and wildfire conditions in the upper Rio Hondo Basin. The U.S. Geological Survey (USGS), in cooperation with Lincoln County, initiated a study in 2006 to assess and characterize water resources in the upper Rio Hondo Basin. Data collected during water years 2010-13 are presented and interpreted in this report. All data presented in this report are described in water years unless stated otherwise.

The upper Rio Hondo Basin, located in south-central New Mexico, experienced extreme drought conditions and two major wildfires from 2011 to 2013. Total annual precipitation was 12.0 inches in 2011 and 13.7 inches in 2013 at the Ruidoso climate station, representing the 1st and 4th, respectively, lowest totals on record at this climate station. Annual Palmer Drought Severity Index values indicate that New Mexico Climate Division 6, which contains the upper Rio Hondo Basin, experienced extreme drought from April 2011 to August 2013. In April 2011, the White Fire burned approximately 16 square miles $\left(\mathrm{mi}^{2}\right)(10,300$ acres$)$ near the city of Ruidoso Downs, N. Mex., in the lower reaches of the Rio Ruidoso watershed. In June 2012, the Little Bear Fire burned approximately $69 \mathrm{mi}^{2}$ (44,300 acres) in the highelevation forests of the Rio Bonito and Ruidoso watersheds.

Streamflow data were collected from two USGS streamflow-gaging stations in the upper Rio Hondo Basin: Rio Ruidoso at Hollywood, N. Mex. (08387000), and Eagle Creek below South Fork near Alto, N. Mex. (08387600). Annual mean streamflow at the Rio Ruidoso at Hollywood streamflow-gaging station was less than 50 percent of the average mean annual of $18.3 \mathrm{ft}^{3} / \mathrm{s}$ during 2011-13 and was of similar magnitude to annual mean streamflow values measured during the drought of the 1950s. Minimal increases in streamflow at the Rio Ruidoso at Hollywood streamflowgaging station were observed during spring (March to May) of 2011-13, with 2011 and 2013 near the 10th percentile of historical values. In addition, the first zero-streamflow values for the period of record (1954-2013) were recorded at the Rio Ruidoso at Hollywood streamflow-gaging station on June 27-29, 2013. The lowest annual mean streamflow on record (1969-80; 1988-2013) occurred in 2011 at the Eagle Creek below South Fork near Alto streamflow-gaging station, with the station recording zero streamflow for approximately 50 percent of the year.

Discrete and continuous groundwater-level measurements indicated basinwide water-level declines during drought conditions in 2011-13. Discrete groundwater-level measurements were made approximately bimonthly in 37 wells between 2010 and 2013, and rises or declines in groundwater levels collected during 2010-13 were determined by calculating the difference in water levels from September 2009 to September 2013. The average water-level change among all 37 wells was $-7.6 \mathrm{ft}$ with several wells exhibiting declines of more than $25 \mathrm{ft}$. The largest water-level declines were observed in the upper reaches of the Rio Bonito and Rio Ruidoso watersheds, and smaller declines were observed in the lower reaches of the watersheds. In general, water-level changes observed during 2010-13, in which a majority of the change occurred during drought conditions of 2011-13, were on the order of decadal-scale changes that previously have been observed in the upper Rio Hondo Basin. Continuous groundwater-level measurements were made in three wells during 2008-13 in which groundwater-level declines on the order of those observed in bimonthly water-level measurements were observed from January 2011 to summer 2013. Although water levels increased in two continuous groundwater wells at the end of 2013 because of an extreme precipitation event, water levels remained near or below minimum values observed during 2008-11.

Stable-isotope data indicate that high-elevation winter precipitation generally contributes more to groundwater recharge than summer rains, except when there are large summer recharge events. This implies that little recharge is occurring at the lower elevations in the upper Rio Hondo Basin because these areas receive a smaller amount of total precipitation, receive a smaller proportion of the annual total falling as winter precipitation, and have higher average temperatures that result in more evaporative losses. Radioisotope data also indicate that groundwater in the upper Rio Hondo Basin is a mix of younger and older water, and recharge likely is occurring primarily at higher elevations but there may be some areas where localized recharge is occurring at lower elevations.

Surface-water- and groundwater-quality results from samples collected in 2012-13 were examined to characterize overall chemistry and were compared to historical waterquality data from streams in the upper Rio Hondo Basin collected during 1926-57. In general, specific conductance showed an increasing trend moving eastward (downstream) through the upper Rio Hondo Basin in surface-water and groundwater samples. Surface-water and groundwater samples appear to have similar overall major-ion chemical characteristics when compared to historical water-quality data in which samples were also collected during drought conditions. All samples could be characterized as calciumtype, with variability in relative major-anion concentration 
(bicarbonate, sulfate, and chloride). Geology was found to influence the chemical characteristics of surface-water and groundwater samples, with relatively higher concentrations of sulfate occurring in samples collected at lower elevations in the Permian regional aquifer system.

Surface-water sample results also were analyzed to determine differences in unfiltered and filtered water-quality samples of streams in burned and unburned watersheds after the occurrence of the Little Bear Fire in June 2012. Samples were collected after postfire monsoon rain events and during periods of stable hydrologic conditions. The first postfire monsoon rain event in July 2012 generally produced the highest measured concentrations of selected fire-related constituents in unfiltered samples collected in the burned watersheds relative to later samples collected in burned watersheds and all samples collected in the unburned watershed. Despite no obvious indications of major changes to water quality in the Rio Bonito after the Little Bear Fire during stable hydrologic conditions, it is evident that monsoon rain events affect water quality by delivering larger sediment loads and fire-related constituents into streams in the upper Rio Hondo Basin.

Changes in climate (including drought, the occurrence of wildfires, and shifts in the variability and distribution of precipitation) and increased groundwater- and surface-water use are likely to affect the availability of water in the upper Rio Hondo Basin. Increased drought probably will increase the potential for wildfires, which can affect downstream water quality and increase flood potential. Climate-research predicted decreases in winter precipitation may have an adverse effect on the amount of groundwater recharge that occurs in the upper Rio Hondo Basin, given the predominance of winter precipitation recharge as indicated by the stable isotope results. Decreases in surface-water supplies because of persistent drought conditions and reductions in the quality of water because of the effects of wildfire may lead to a larger reliance on groundwater reserves in the upper Rio Hondo Basin. Decreasing water levels because of increasing groundwater withdrawal could reduce base flows in the Rio Bonito and Rio Ruidoso. Well organized and scientificallysupported regional water-resources management will be necessary for dealing with a scenario of increases in demand coupled with decreases in supply in the upper Rio Hondo Basin.

\section{References Cited}

Allen, C.D., Macalady, A.K., Chenchouni, H., Bachelet, D., McDowell, N., Vennetier, M., Kitzberger, T., Rigling, A., Breshears, D.D., Hogg, E.H., Gonzalez, P., Fensham, R., Zhang, Z., Castro, J., Demidova, N., Lim, J.H., Allard, G., Running, S.W., Semerci, A., and Cob, N., 2010, A global overview of drought and heat-induced tree mortality reveals emerging climate change risks for forests: Forest Ecology and Management, v. 259, p. 660-684.
Barlow, P.M., and Leake, S.A., 2012, Streamflow depletion by wells-Understanding and managing the effects of groundwater pumping on streamflow: U.S. Geological Survey Circular 1376, 84 p.

Childress, C.J. Oblinger; Foreman, W.T.; Connor, B.F.; Maloney, T.J., 1999, New reporting procedures based on long-term method detection levels and some considerations for interpretations of water-quality data provided by the U.S. Geological Survey National Water Quality Laboratory: U.S. Geological Survey Open-File Report 99-193, 19 p.

Clark, I.D., and Fritz, Peter, 1997, Environmental isotopes in hydrogeology: Boca Raton, Fla., Lewis Publishers, 328 p.

Clow, D.W., 2010, Changes in the timing of snowmelt and streamflow in Colorado-A response to recent warming: Journal of Climate, v. 23, p. 2293-2306.

Craig, Harmon, 1961, Isotopic variations in meteoric waters: Science, v. 133 , no. 3465 , p. $1702-1703$.

Cunningham, W.L., and Schalk, C.W., comps., 2011a, Groundwater technical procedures of the U.S. Geological Survey, GWPD 1-Measuring water levels by use of a graduated steel tape: U.S. Geological Survey Techniques and Methods, book 1, chap. A1, 4 p.

Cunningham, W.L., and Schalk, C.W., comps., 2011b, Groundwater technical procedures of the U.S. Geological Survey, GWPD 16-Measuring water levels in wells and piezometers by use of a submersible pressure transducer: U.S. Geological Survey Techniquesand Methods, book 1, chap. A1, 6 p.

Darr, M.J., Rattray, G.W, McCoy, K.J., and Durall, R.A., 2014, Hydrogeology, water resources, and water budget of the upper Rio Hondo Basin, Lincoln County, New Mexico, 2010: U.S. Geological Survey Scientific Investigations Report 2014-5153, 72 p.

Dettinger, Michael, 2005, Changes in streamflow timing in the Western United States in recent decades: U.S. Geological Survey Fact Sheet 2005-3018, 4 p.

Donohoe, L.C., 2004, Selected hydrologic data for the upper Rio Hondo Basin, Lincoln County, New Mexico, 19452003: U.S. Geological Survey Scientific Investigations Report 2004-5275, 28 p.

Eastoe, C.J., and Rodney, Ryan, 2014, Isotopes as tracers of water origin in and near a regional carbonate aquifer-The southern Sacramento Mountains, New Mexico: Water, v. 6, p. $301-323$.

Fishman, M.J., ed., 1993, Methods of analysis by the U.S. Geological Survey National Water Quality LaboratoryDetermination of inorganic and organic constituents in water and fluvial sediments: U.S. Geological Survey OpenFile Report 93-125, 217 p. 
Fishman, M.J., and Friedman, L.C., 1989, Methods for determination of inorganic substances in water and fluvial sediments: U.S. Geological Survey Techniques of WaterResources Investigations, book 5, chap. A1, 545 p.

Garbarino, J.R., Kanagy, L.K., and Cree, M.E., 2006, Determination of elements in natural-water, biota, sediment and soil samples using collision/reaction cell inductively coupled plasma-mass spectrometry: U.S. Geological Survey Techniques and Methods, book 5, sec. B, chap. 1, 88 p.

Garfin, G., Jardine, A., Merideth, R.T., Black, M., and LeRoy, S., eds., 2013, Assessment of climate change in the Southwest United States-A report prepared for the National Climate Assessment: Washington, D.C., Island Press, $531 \mathrm{p}$.

Hall, A.W., Whitfield, P.H., and Cannon, A.J., 2006, Recent variations in temperature, precipitation, and streamflow in the Rio Grande and Pecos River Basins of New Mexico and Colorado: Reviews in Fisheries Science, v. 14, p. 51-78.

Hall, F.R., 1964, Chemistry of water of a section of the eastern flank of the Sacramento Mountains, Lincoln and Otero Counties, New Mexico, in Ash, S.R., and Davis, L.R., eds., Ruidoso Country: New Mexico Geological Society, 15th field conference, Guidebook, p. 161-170.

Helsel, D.R., and Hirsch, R.M., 2002, Statistical methods in water resources: U.S. Geological Survey Techniques of Water-Resources Investigations, book 4, chapter A3, 522 pages. [Also available at http://pubs.usgs.gov/twri/twri4a3/.]

Hoy, R.N., and Gross, G.W., 1982, A baseline study of oxygen-18 and deuterium in the Roswell, New Mexico, groundwater basin: New Mexico Water Resources Research Institute Report 144, 95 p.

Karl, T.R., and Knight, R.W., 1998, Secular trends of precipitation amount, frequency, and intensity in the United States: Bulletin of the American Meteorological Society, v. 79 , no. 2, p. 231-241.

Kendall, Carol, and McDonnell, J.J., eds., 1998, Isotope tracers in catchment hydrology: Amsterdam, Elsevier Science, B.V., 839 p.

Knowles, N., Dettinger, M.D., and Cayan, D.R., 2006, Trends in snowfall versus rainfall in the western United States: Journal of Climate, v. 19, p. 4545-4559.

Land, Lewis, and Huff, G.F., 2010, Multi-tracer investigation of groundwater residence time in a karstic aquifer-Bitter Lakes National Wildlife Refuge, New Mexico, USA: Journal of Hydrogeology, v. 18, 455-472.

Matherne, A.M., Myers, N.C., and McCoy, K.J., 2010, Hydrology of Eagle Creek Basin and effects of groundwater pumping on streamflow, 1969-2000: U.S. Geological Survey Scientific Investigations Report 2010-5205, 73 p. (Revised November 2010.)
Milly, P.C.D., Betancourt, J., Falkenmarh, M., Hirsch, R.M., Kundzewicz, Z.W., Lettenmaier, D.P., and Stouffer, R.J., 2008, Stationarity is dead-Whither water management?: Science, v. 319, no. 5863, p. 573-574.

Moody, J.A., and Martin, D.A., 2001, Hydrologic and sedimentologic response of two burned watersheds in Colorado: U.S. Geological Survey Water-Resources Investigations Report 01-4122, 138 p.

Mourant, Walter, 1963, Water resources and geology of the Rio Hondo drainage basin, Chaves, Lincoln, and Otero Counties, New Mexico: New Mexico State Engineer Technical Report 28, 85 p., 7 pls.

National Oceanic and Atmospheric Administration, National Climatic Data Center, 2014a, Climate data online: National Oceanic and Atmospheric Administration, National Climatic Data Center, accessed January 16, 2014, at http://www. ncdc.noaa.gov/cdo-web/.

National Oceanic and Atmospheric Administration, National Climatic Data Center, 2014b, NCDC temperature, precipitation and drought: National Oceanic and Atmospheric Administration, National Climatic Data Center, accessed February 3, 2014, at http://www.ncdc.noaa. gov/temp-and-precip/.

National Ocean Sciences Accelerator Mass Spectrometry Facility, 2010, General statement of ${ }^{14} \mathrm{C}$ procedures at the National Ocean Sciences AMS Facility, accessed September 2014 at http://www.nosams. whoi.edu/images/amsgenst.pdf.

Natural Resources Conservation Service, 2014, NRCS National Water and Climate Center SNOTEL data and products, accessed January 21, 2014, at http://www.wcc. nrcs.usda.gov/snow/.

Neary, D.G., Ryan, K.C., and DeBano, L.F., eds., 2008, Wildland fire in ecosystems-Effects on soils and water [revised from 2005]: Ogden, Utah, U.S. Department of Agriculture, Forest Service, Rocky Mountain Research Station, General Technical Report RMRS-GTR-42, v. 4, $250 \mathrm{p}$.

Newcomer, R.W., Jr.; and Shomaker, J.W., 1991, Water resources of the Ruidoso-Carrizozo-Tularosa areas, Lincoln and Otero Counties, New Mexico, in Barker, J.M., Kues, B.S., Austin, G.S., and Lucas, S.G., eds., Geology of the Sierra Blanca, Sacramento, and Capitan Ranges, New Mexico: New Mexico Geological Society, 42nd field conference, Guidebook, p. 339-341.

New Mexico Environment Department Surface Water Quality Bureau, 2003, Water quality survey summary for the Rio Hondo watershed (Rio Ruidoso and selected tributaries): Accessed June 25, 2014, at http://www.nmenv.state.nm.us/ swqb/documents/swqbdocs/MAS/Surveys/RioHondo SurveyReport -2003.pdf. 
Newton, B.T., Rawling, G.C., Timmons, S.S., Land, L., Johnson, P.S., Kludt, T.J., and Timmons, J.M., 2012, Sacramento Mountains hydrogeology study: New Mexico Bureau of Geology and Mineral Resources Open-File Report 543, 77 p.

Palmer, Wayne, 1965, Meteorological drought: Washington, D.C., U.S. Weather Bureau, NOAA Library and Information Services Division, research paper no. 45.

Piper, Arthur, 1944, A graphic procedure in the geochemical interpretation of water analysis: American Geohysical Union Transactions, v. 25, p. 914-923.

Plummer, L.N., Bexfield, L.M., Anderholm, S.K., Sanford, W.E., and Busenberg, Eurybiades, 2012, Geochemical characterization of ground-water flow in the Santa Fe Group aquifer system, Middle Rio Grande Basin, New Mexico (ver. 1.2, November 20, 2012): U.S. Geological Survey Water-Resources Investigations Report 03-4131, 395 p.

Ranalli, Anthony, 2004, A summary of the scientific literature on the effects of fire on the concentration of nutrients in surface waters: U.S. Geological Survey Scientific Open-File Report 2004-1296, 23 p.

Rawling, Geoffrey, 2011, Gelogy of the Ruidoso area, Lincoln and Otero Counties, New Mexico: New Mexico Bureau of Geology and Mineral Resources Open-File Report OFR507 , scale $1: 24,000$.

Révész, Kinga, and Coplen, T.B., 2008a, Determination of the $\delta\left({ }^{2} \mathrm{H} /{ }^{1} \mathrm{H}\right)$ of water: RSIL lab code 1574 , chap. C1 of Révész, Kinga, and Coplen, T.B., eds., Methods of the Reston Stable Isotope Laboratory: U.S. Geological Survey Techniques and Methods 10-C1, $27 \mathrm{p}$.

Révész, Kinga, and Coplen, T.B., 2008b, Determination of the $\delta\left({ }^{18} \mathrm{O} /{ }^{16} \mathrm{O}\right)$ of water: RSIL lab code 489 , chap. C2 of Révész, Kinga, and Coplen, Tyler B., eds., Methods of the Reston Stable Isotope Laboratory: U.S. Geological Survey Techniques and Methods, 10-C2, $28 \mathrm{p}$.

Riesterer, Jim, Drakos, Paul, Lazarus, Jay, and Chudnoff, Mustafa, 2006, Hydrogeology of Hale Spring and evaluation of declining spring discharge, Ruidoso Downs, New Mexico: New Mexico Geological Society Guidebook, 57 th Field Conference, Caves and Karst of Southeastern New Mexico, 2006, p. 287-296.

Rounds, Stewart, 2006, Alkalinity and acid neutralizing capacity (ver. 3.0): U.S. Geological Survey Techniques of Water-Resources Investigations, book 9, chap. A6., sec. 6.6, accessed June 10, 2014, at http://pubs.water.usgs.gov/ twri9A6/.

Smith, H.G., Sheridan, G.J., Lane, P.N.J., Nyman, P., and Haydon, S., 2011, Wildfire effects on water quality in forest catchments - A review with implications for water supply: Journal of Hydrology, v. 396, p. 170-192.
Snyder, Jim, Banks, April, Brown, Paul, and Lovely, Collis, 2012, 2012 Little Bear Fire, BAER hydrology report: U.S. Department of Agriculture, Forest Service, Southwestern Region, Lincoln National Forest, 20 p.

Solomon, D.K., and Cook, P.G., 2001, Chapter 13-3 ${ }^{3} \mathrm{H}$ and ${ }^{3} \mathrm{He}$, in Cook, P.G., and Herczeg, A.L., eds., Environmental tracers in subsurface hydrology: Boston, Kluwer Academic Publishers, p. 397-424.

Southwest Fire Science Consortium, 2013, 2011 White/ Donaldson Fires New Mexico: Accessed December 8, 2014, at http://swfireconsortium.org/wp-content/uploads/2014/04/ Final_WD-fact-sheet-4-1-13.pdf.

Stallings, Dianne, 2012, Fire aftermaths ruins Bonito Lake: Ruidoso [New Mexico] Ruidoso News, July 13, 2012, accessed March 9, 2015, at http://www.elpasotimes.com/ ci_21065561/fire-aftermath-ruins-bonito-lake.

Stevens, M.R., 2013, Analysis of postfire hydrology, water quality, and sediment transport for selected streams in areas of the 2002 Hayman and Hinman fires, Colorado: U.S. Geological Survey Scientific Investigations Report 2012$5267,93 \mathrm{p}$.

Stewart, Iris, 2009, Changes in snowpack and snowmelt runoff for key mountain regions: Hydrological Processes, v. 23, p. 78-94.

Thatcher, L.L., Janzer, V.J., and Edwards, K.W., 1977, Methods for determination of radioactive substances in water and fluvial sediments: U.S. Geological Survey Techniques of Water-Resources Investigations, book 5, chap. A5, 95 p.

Thompson, Tommy, 1964, A stratigraphic section of the Sierra Blanca Volcanics in the Nogal Peak area, Lincoln County, New Mexico: New Mexico Geological Society Guidebook 15 , p. 76-77.

Tillery, A.C., and Matherne, A.M., 2013, Postwildfire debrisflow hazard assessment of the area burned by the 2012 Little Bear Fire, south-central New Mexico: U.S. Geological Survey Open-File Report 2013-1108, 15 p., 3 pls.

University of Nebraska-Lincoln, 2014, United States drought monitor maps and data: Accessed February 3, 2014, at http:// droughtmonitor.unl.edu/MapsAndData.aspx.

Unterweger, M.P., and Lucas, L.L., 2000, Calibration of the National Institute of Standards and Technology tritiatedwater standards: Applied Radiation and Isotopes, v. 52, p. 527-531.

U.S. Environmental Protection Agency, 2014, Secondary Drinking Water Regulations - Guidance for nuisance chemicals: Accessed June 2, 2014, at http://water.epa.gov/ drink/contaminants/secondarystandards.cfm.

U.S. Geological Survey, 2006, Collection of water samples (ver. 2.0): U.S. Geological Survey Techniques of WaterResources Investigations, book 9, chap. A4, accessed May 25, 2014, at http://pubs.water.usgs.gov/twri9A. 
U.S. Geological Survey, 2014, USGS water data for New Mexico: Accessed April 24, 2014, at http://nwis.waterdata. usgs.gov/nm/nwis.

Vuataz, F.D., and Goff, Fraser, 1986, Isotope geochemistry of thermal and nonthermal waters in the Valles Caldera, Jemez Mountains, northern New Mexico: Journal of Geophysical Research, v. 91, no. B2, p. 1835-1853.
Westerling, A.L., Hidalgo, H.G., Cayan, D.R., and Swetnam, T.W., 2006, Warming and earlier spring increase Western U.S. forest wildfire activity: Science, v. 313, p. 940-943.

Writer, J.H., and Murphy, S.F., 2012, Wildfire effects on source-water quality-Lessons from Fourmile Canyon fire, Colorado, and implications for drinking-water treatment: U.S. Geological Survey Fact Sheet 2012-3095, 4 p. 
